folk/ed. Derg, 2020; 26(4):813-825

DOI: $10.22559 /$ folklor.1341

\title{
Metinlerarasılık Bağlamında Kurt ile Kıyamete Kalmak Anlatısının Dönüşümü
}

\section{Transformation of the Narrative of Doomsday with the Wolf in the Context of Intertextuality}

\section{Gülcan Kızılözen*}

Öz

Sözlü kültür ürünlerinin, yaratım ve aktarım bağlamında, daima dinamik bir yapıya sahip oldukları bilinmektedir. Özellikle anlatıya dayalı ürünler zamana ve üretilip aktarıldıkları coğrafyaya bağlı olarak yenilenmekte ve bu yolla var olmaktadırlar. Bununla birlikte bazı kültürel değişimler sonucunda unutulmaya yüz tutan anlatmaların bir kısmı yapı ve işlev bakımından başkalaşıma uğrayarak sözlü kültürde yaşamaya devam edebilir. Bu duruma örnek olarak, incelememizde kıyamet konulu bir anlatının zamanla unutularak bir deyim olarak kalıplaşması, deyime dönüşen bu anlatının daha sonra anlam kötüleşmesine uğrayarak yergi amacıyla kullanılması ele alınmıştır. Kayseri, Yozgat, Azerbaycan ve İran'ın Halhal şehrinden farklı tarihlerde, farklı araştırmacılar tarafından derlenmek suretiyle yazıya geçirilmiş bu anlatmalar metinlerarası bağlamda incelenmiş, anlatmaların zaman içinde gerek konu gerek işlev ve yapı bakımından değişikliğe uğrayarak beddua, alay amaçlı bir deyime dönüştüğü tespit edilmiştir. Türk köken mitleriyle bağlantılı olan, kıyamet gününde yalnızca yaşlı bir kadın ve kurdun hayatta kalacağının bildirildiği bu anlatmalar içerik ve söylem bakımından çözümlenmiştir. Zaman içerisinde, inanç bağlamında kurt ve kadının kutsallığı algısı kültür dünyamızdan uzaklaşmaya baş-

Geliş tarihi (Received): 01.06.2020- Kabul tarihi (Accepted): 19.08.2020

Dr. Öğretim üyesi. İnönü Üniversitesi Fen-Edebiyat Fakültesi, Türk Halk Edebiyatı. gulcangulmezz@hotmail. com. ORCID 0000-0001-8266-6276 
lamıştır. Bu nedenle sözlü kültürde yaşayan kurt ile kıyamete kalmak deyiminde bu iki motif tamamen olumsuz bir karaktere bürünmüştür. Ancak, anlam ve söylem bakımından gerçekleşen olumsuz durum, kurt ve kadına dair kıyamet söyleminin gelenekten silinip gitmesini engellemiş̧ir. Bu bağlamda kurt ile kıyamete kalmak bir deyim olarak sözlü kültürümüzdeki yolculuğuna devam etmektedir.

Anahtar sözcükler: kurt, kadın, klyamet, deyim, metinlerarasılık

\begin{abstract}
In the context of creation and transfer, oral culture products are known to always have a dynamic structure. In particular, narrative products are renewed depending on the time and the geography where they are produced and transferred, and they exist through this. However, some of the narratives that are forgotten as a result of some cultural changes may continue to live in oral culture by being transformed in terms of structure and function. This study, as an example, focuses on the expression of apocalyptic narrative as it is being withdrawn from use, and this narrative, which turns into an idiom, is used for the purpose of satirical by worsening the meaning. These narratives, which were written by different researchers on different dates from the anklet city of Kayseri, Yozgat, Azerbaijan, and Khalkhal (Iran), were examined in an intertextual context, and it was determined that the narrations changed in terms of subject, function and structure, and turned into an idiomatic expression. These narratives, which are associated with the myths from Turkish origin, where only an old woman and a wolf are going to survive on the day of resurrection, have been analyzed in terms of content and discourse. Over time, the sense of holiness of the wolf and the woman in the context of belief began to move away from our cultural world. For this reason, these two motifs take on a completely negative character in the phrase of staying in apocalypse with the wolf living in the oral culture. However, the negativity in terms of meaning and discourse prevented the apocalypse discourse about the wolf and the woman from disappearing from the tradition. In this context, the apocalypse with the wolf continues its journey in our oral culture as an idiom.
\end{abstract}

Keywords: wolf, woman, doomsday, idiom, intertextuality

\title{
Extended summary
}

This article focuses on an apocalyptic narrative linked to Turkish origin myths. The apocalyptic narrative with seven variants in our study is from Khalkhal (Iran), Kayseri, Yozgat and Azerbaijan. The narrative of Khalkhal, which is found in four identical texts, has been compiled by me. The Yozgat text was compiled by M. Öcal Oğuz and the Kayseri text by Harun Güngör. The Azerbaijani text was quoted by M. Öcal Oğuz from a website. In our article, doomsday narratives and the statement of doomsday with a wolf are examined in the context of intertextuality.

In the first part of the review, the seven variants of Kurt and the doomsday narrative were first compared in terms of their elements. Accordingly, the different and common motifs in the variants are shown in a table. Second, the discourse analysis of the narratives has 
been done. As a result of this analysis, the relationship between the narratives and the oral narrative tradition was discussed. In the second part of the study, the use of the phrase " doomsday with a wolf " in today's oral culture is analyzed.

During our fairy tale studies between 2006-2007, we became aware of a legend in Iran that is an explanation of the phrase "doomsday with a wolf". We transferred this narrative, which we heard from Fatma Tesellizâde, into writing. In 2009, the study titled "A New Expression of the Eschatological Background of the Idiom of Doomsday with a Wolf and What It Makes Thinking" was the subject of this legend. I presented as a declaration at the International Turkic World Cultural Congress in Çeşme in 2010. Again in 2010, we went to Iran to do fieldwork for our doctoral thesis on legend. Here, after listening to and recording the legend from Fatma Tesellizade, we determined that the legend was known by three more different narrators and recorded these narratives. As a result, we analyzed the four narratives we have by explaining their motifs in the "End of the World (Doomsday)" section in our thesis that we completed in 2012. However, we determined the necessity to deal with the variants of these narratives written by different researchers and all the uses of the phrase wolf and doomsday in oral culture. For this reason, we have included texts found by other researchers in our review.

The first of the other narratives that we have included in this article is included in Harun Güngör's article "Beliefs Related to Animals in the Village of Uzerlik", which was published in the Gift of Prof. Dr. Dursun Yıldirım in 1998. The other two narratives in our study are included in the article "Eschatological Adventure of Cosmogonic Myth in the Witnessing of Kul Himmet and Oral Tradition" by M. Öcal Oğuz.

The texts we have examined are coded with the initials of the fields they belong to. The Kayseri narrative is coded with the letter K, the Yozgat narrative Y, the Azerbaijani narrative A and the Khalkhal narrative with the letter H. We can say that the legend of doomsday with the wolf has lost its place in the people's world of thought over time, but lived in variants in places where oral tradition and old beliefs are strong. At this point, the narrative of the wolf, who is confronted with a process such as freezing and being forgotten, has turned into an expression that is used for curse purposes by changing the shell. It has been possible to categorize the spouse texts we have examined in three groups. First group; Kayseri, Yozgat and Azerbaijan, second group; The third group consists of the narratives numbered 1, 2 and 4 compiled from the anklet, and the third group consists of the narrative number 3 belonging to the Khalkhal. The Kayseri, Yozgat and Azerbaijan narratives in the first group reveal a definite conclusion or doomsday view. In the H1, H2 and H4 narratives in the second group, there is not a definite ending, but a cyclical process. The cyclical time seen in the narratives in the second group shows that these narratives are products of oral culture. The H3 narrative includes the motif of wrestling, but emphasizes the possibility that the wolf will defeat the woman and mentions a definite apocalypse. That is to say, a cyclical ending is perceived in this narrative; it can be said, however, that the narrator is inclined to a non-cyclical, definitive vision of doom. In this respect, H3 narration serves as a transition between the first and the second group. 
Over time, the doomsday narrative, which came to the point of being frozen and forgotten due to the changes in the belief structures of the Turks and various social changes, was transformed in terms of subject and structure in accordance with the tradition and continued to live in oral culture with the word doomsday with the wolf.

\section{Giriş}

İnsanın dünya üzerindeki varlığını sorgulaması, nasıl yaratıldığı ve nasıl yok olacağı ile ilgili bilinmezliklerin peşine düşmesi evrensel ölçekte ele alınabilecek bir sorundur. $\mathrm{Bu}$ sorun insanlığın temel düşünsel sorunlarından biridir. Ancak, insanlığın bu temel düşünce sorunu her yerde bir ve benzer şekilde çözümlenmemiştir. Şöyle ki zaman içinde aynı dili konuşan ve aynı kültür dairesi içinde yaşayan insanların kendilerine özgü dünya görüşlerinin oluşmasıyla her bir kültür dairesi yaratılışın nasıl gerçekleşmiş olabileceği, köklerinin nereye dayandığı ve kıyamet gününde nelerle karşılaşabilecekleri ile ilgili kendilerine özgü cevaplar bulmuşlardır. Böylesi ciddi ve gizemli konulara karşılık verilen cevaplar gerçeğin ta kendisi olarak efsane ya da mit türünden anlatılarla kuşaktan kuşağa aktarılmıştır. Hiç kuşkusuz Türk kültüründe de bu tip anlatılar gelenek içerisinde yerini almıştır. $\mathrm{Bu}$ anlamda Türk köken mitleri yazılı kaynaklar aracılığıyla günümüze ulaşmıştır; ancak köken mitleriyle bağlantılı kıyamet tasavvurunun, yani kurt ve kadın motifleriyle örülmüş anlatıların daha eski tarihli yazılı kaynaklarda görülmediği bilinmektedir. Son dönemlerde yapılan saha araştırmalarında ise, Türk köken mitleriyle bağlantılı bir kıyamet anlatısının varlı̆̆ 1 tespit edilmiştir. ${ }^{1}$

Elimizde hem İran'ın Halhal ilinden tarafımızca derlenen, dört eş metin halindeki kıyamet anlatısı (Karini, 2012: 330-331) hem de Harun Güngör'ün Kayseri'den (Güngör, 1998: 62) ve Öcal Oğuz'un Yozgat'tan derlemek suretiyle yazıya geçirdikleri anlatılar ile Oğuz'un internetten alıntıladığı bir Azerbaycan anlatısı mevcuttur (Oğuz, 2009: 51-56). Ayrıca, bu anlatıyla bağlantılı olarak, Kayseri, Yozgat ve Halhal yörelerinde kullanılan kurt ile klyamete kalmak deyiminin yer aldığı ilenme, alay etme amaçlı kullanımlar incelememizde yer almaktadır. Amacımız, kurtla kıyamete kalmak anlatısının elimizde bulunan eş metinlerini analiz etmek ve Türklerde kıyamet söyleminin sosyal değişmelere bağlı olarak hem konu hem de şekil ve yapı bakımından geçirdiği dönüşümü açıklığa kavuşturmaktır. Bu incelemede, yukarıda söz ettiğimiz, kıyamet konulu efsaneler ve bu efsanelerle eş zamanlı olarak yaşayan; ancak bambaşka bir söyleme dönüşmüş olan kurt ile klyamete kalmak deyimine bağlı sözler metinlerarası bir yaklaşımla ele alınacaktır. Bu anlatılar ve kurt ile kıyamete kalmak deyiminin geçtiği kalıp söyleyişler birer halk bilgisi ürünü olmaları dolayısıyla gelenek içerisinde yaşayan ürünlerdir. Birer halk bilgisi ürünü olan bu anlatılar diğer halk bilgisi ürünleri gibi yaşayan birer kültür öğesidir. Bu bakımdan özellikle anlatıya dayalı türlerin canlı organizmalar gibi bir yaşama sahip olduklarını söylemek yerinde olacaktır. Başlangıçta belli anlatıcılar tarafından yaratılıp aktarılmış olan bu ürünlerin zaman içinde yaratıcıları unutulsa da o ürünler bir topluluğun geleneksel bir unsuru haline gelerek dolaşımına devam etmektedir. $\mathrm{Bu}$ anlatılar, hangi kültür içinde yaratılmışsa, o kültürün ortak ürünü olarak kuşaktan kuşağa 
aktarılmakta hatta yazıya geçirilerek yazılı kültür ortamında yaşamaktadır. Yaşayan bir unsur olması dolayısıyla toplumun ya da yaratıldığı kültürün geçirmiş olduğu değişimlerle birlikte bu ürünler de bir değişim, dönüşüm geçirebilmektedir.

Sözlü kültürde var olan anlatı türlerinin yolculuğu çeşitli araştırmacılarca söylemlerarasılık ve bu ürünlerin yazıya aktarıldıktan sonraki biçimleri metinlerarasılık bağlamında değerlendirilmiştir. Kubilay Aktulum bu kavramları; "Sözlü ürünler konusunda bir alıcı ve verici arasında sözel bir alışveriş gerçekleştiğine göre sözcenin ana indirgenen ve belli bir süreyi kapsayan üretim süreci bir söylemlerarasılık (Fr. interdiscursivité); sözlü ürünler metinleştirildikleri anda ise söylemlerarasılık sürecinin bir sonucu olan metinlerarasılık (Fr. intertextualité) işlemeye başlar” (Aktulum, 2013: 21) şeklinde izah etmektedir. Bu bilgiden hareketle sözlü kültür ortamında yaratılıp aktarılan halk bilgisi ürünleri söylemlerarasılık, bu ürünlerin yazıya geçirildikten sonraki biçimleri ise metinlerarasılık bağlamında incelenip açıklanabilir. Söylemlerarasılık, halk bilimi araştırmaları özelinde, sözlü kültürde ortaya çıkan sözel aktarımların anlatıcı ve dinleyici bağlamında icra sürecine gönderme yapar. Aynı anlatı ya da kalıp sözler farklı anlatıcılar tarafından çeşitli değişikliklerle sunulabileceği gibi aynı anlatıcının farklı icralarında da bir değişim, dönüşüm yaşayabileceğini söyleyebiliriz. Metinlerarasılıkta ise, bir anlatı metninin her bir aktarma sonucunda ortaya çıkan hali yeni bir metin olarak kabul edilmekte ve eş metin olarak adlandırılan bu metinler arasındaki ilişkiler irdelenmektedir. Ancak, kimi kez söylemlerarasılık ve metinlerarasılık eş anlamlı olarak kullanılmışlardır. Bunun nedeninin ise, her ikisinde de "bağlam" ve "dönüştürüm” gibi kavramların ortak olmasıdır (Aktulum, 2013: 28). Yani, her ikisinde de anlatının yaratım bağlamı ve her aktarmada dönüşen karakteri belirlenmeye çalışılmaktadır.

Bağlama göre yeniden üretilip aktarılan metinler, önceki metinlerden tümüyle bağımsız değildir. Bauman'ın "Metinlerarası ilişkiyle benim kastettiğim şey, bir metnin diğer metinlere ilişkisel yönelimidir" ifadesinde bunu net olarak görebiliriz. Ayrıca Bauman; "metinselleştirme ayrıştırmayı etkili hale getirir. Ancak bu şekilde bir bağlamdan ayrıştırma işi bir başka bağlama yeniden yerleştirme işlemini içermek zorundadır ki bu, metnin dolaşımda olma potansiyelini, yeniden bir başka bağlamda konuşulmasını kabul etmektir. Bu durumda, metinlerin tekrar edilebilirliği metinlerarası ilişkinin üretiminin ve sağlamlaştırılmasının en güçlü temelini oluşturur" (Bauman, 2008: 116) demek suretiyle yeniden aktarıma giren metinlerin birbirlerinden tamamen kopuk olmamakla birlikte bir ayrışma sürecine girerek sözlü gelenekte metinlerarası ilişkinin devamlılığını sağladığını belirtmektedir. Bu bağlamda kurtla kıyamete kalmak efsanesinin sözlü kaynaklardan derlenerek yazıya geçirilen eş metinleri ve daha sonra bu efsaneden bazı motifleri alıntılayarak ilenme amaçlı bir deyime dönüşen kurt ile kıyamete kalmak deyimi ayrıntılı bir değerlendirmeye ihtiyaç duymaktadır.

\section{İnceleme}

2006-2007 yılları arasında yürüttüğümüz masal çalışmalarımız sırasında, İran’da “kurtla kıyamete kalmak" deyiminin açıklaması mahiyetinde olan bir efsaneden haberdar olduk. Fatma Tesellizâde'den dinlediğimiz bu anlatıyı yazıya aktardık. Bu efsaneyi konu edinen "Kurtla kıyamete kalmak deyiminin eskatolojik arka planına dair yeni bir anlatma ve düşündürdükleri” 
adlı incelememizi 2010 yılında İzmir-Çeşme'de düzenlenen II. Uluslararası Türk Dünyası Kültür Kurultayı'nda bildiri olarak sunduk (Gülmez, 2010). Yine 2010 yılında efsane konulu doktora tezimiz için saha çalışmaları yapmak üzere İran'a gittik. Burada efsaneyi Fatma Tesellizade'den tekrar dinleyip kaydettikten sonra, efsanenin üç farklı anlatıcı tarafindan daha bilindiğini tespit edip bu anlatmaları da kayıt altına aldık. Sonuç olarak, elimizde bulunan dört anlatmayı 2012 yılında tamamladığımız tezimizde yer alan “Dünyanın Sonu (Kıyamet)” bölümünde motiflerini açıklamak suretiyle inceledik (Karini, 2012: 152-159). Ancak bu anlatmaların farklı araştırmacılarca yazıya geçirilen eş metinleri ve kurt ile kıyamete kalmak deyiminin sözlü kültürdeki tüm kullanımlarını birlikte ele almanın gerekliliğini tespit ettik. Bu nedenle incelememizde öteki araştırmacıların bulduğu metinlere de yer verdik.

Bu makalede yer verdiğimiz diğer anlatılardan ilki, Harun Güngör'ün 1998 yılında Prof. Dr. Dursun Yıldırım Armağanı’nda yayımlanmış olan “Üzerlik köyünde hayvanlarla ilgili inançlar" adlı makalesinde yer almaktadır. Güngör bu incelemede Kayseri’nin Sarığlan ilçesine bağlı Üzerlik köyünde bilinen "Allah, Bozkurtunan kıyamete kalasın.” bedduasının köylüler tarafindan anlatılan efsane metnine yer vermiştir (Güngör, 1998: 62).

İncelememizde yer alan diğer iki anlatı ise, M. Öcal Oğuz'a ait "Kul Himmet ve sözlü gelenek tanıklığında kozmogonik mitin eskatolojik serüveni” adlı makalede yer almaktadır. Araştırmacı bu incelemede Kul Himmet adına kayıtlı bir şiirde "Boz kurt ile kıyamete/Kalan dünya değil misin” dizelerinden yola çıkarak Yozgat (saha çalışması) ve Azerbaycan (internet kaynakl1)'dan naklettiği iki anlatıyı, Türk yazılı ve sözlü kültüründe kozmogonik mitin eskatolojik mite kaynaklık edip etmediği sorgulaması üzerine inşa etmiştir. Yozgat’ta daha çok gelinlerin uzun ömür süren kayınvalidelerine ilenme amaçlı söyledikleri "Ölmedi gitti, kurtla kıyamete mi kalacak ne?” ifadesinin bulunduğunu belirtir (Oğuz, 2009: 51-56).

Bu bölümde inceleyeceğimiz metinler ait oldukları sahaların baş harfleriyle kodlanmıştır. Kayseri anlatısı K, Yozgat anlatısı Y, Azerbaycan anlatısı A ve Halhal anlatıları H harfi ile kodlanmıştır. Dört eş metin halinde bulunan Halhal anlatıları H1, H2, H3 ve H4 biçiminde gösterilmiştir.

\section{Kurt ile kıyamete kalmak anlatısının eş metinleri ve bunların içerik ve söylem bakımından çözümlenmesi}

K. "Kıyamet kopacağı zaman bir kocakarı, bir de Bozkurt kalacakmış, son olarak Bozkurt kocakarıyı da yiyecek ve ondan sonra Azrail Bozkurtun canını alacakmış."

Y. "Bunca bina yapılınca ve zina artınca, kadınlar edep hayayı unutunca, sevgi sayg1 bitince, insanlar yoldan çıkıp ıslâh edilemez hâle gelince aldığı emir üzerine İsrafil Sûr düdügünü üfleyecek. Binalar kâğıt gibi yırtılacak, yer yarılacak herkes yerin altına girecek. İnsanoğlunun izi yeryüzünden silinecek. Geriye sadece acuze bir karı kalacak ve onu da bir kurt yiyecek. İnsanoğlunun sonu böyle olacak."

A. 'Kıyamet günü Sûr'a üflendiğinde, yeryüzündeki bütün canlılar ölecek. Bütün dağlar yerle bir olacak. Ağaçlar köklerinden sökülüp savrulacak. Korkunç bir rüzgâr 
âlemin altını üstüne getirecek. Bütün canlılar-cansızlar yok olurken, bir Boz kurt, ayakta kalmak için direnecek. O korkunç rüzgârda, önce tüyleri dökülecek, sonra derisi soyulacak, etleri lime lime kopacak bedeninden. Acı çekecek, susacak... Ama son ana kadar ayakta kalacak."

H.1. “Allah'ın yarattığı herkes ölür. Bu (kadın) tek kalır. O yüzden ona derler ki niye ölmedi? Gün gelir herkes öldükten sonra bu yaşlı kadın ve kurt güreşirler. Eğer yaşlı kadın kurdu yıkarsa, yine dünya var olacak, herkes dirilecek. Yok, kurt kadını yıkarsa hiçbir şey kalmayacak."

H.2. "Mesela filan kişinin, filan ağanın yaşında burada ağaç yoktur. Mesela yüz on yıl ömür sürer. Filanca kişi kurt ile kıyamete kalacak; ölüm yoktur ona. Biz de öyle işittik ki o kurt kadını yıksa, dünyada hiç kimse kalmayacak. Ben böyle işittim. Yaşlı kadın kurdu yıksa, yine bu millet aynı yerinde olacak. Yine yaşam olacak."

H.3. "Eskiler bu sözleri derler ki herkes kırılacak, ölecek. Sonunda bir kurt kalacak, bir de kocakarı. Onlar da tutuşacaklar, güreşecekler. Hangisi ötekini yıkarsa... Yani kurt kocakarıyı yıksa, onu yiyecek. Ondan sonra mahşer olacak, toprak dökülecek, dağlar uçacak, yer dümdüz olacak, her yer sularla dolacak."

H.4. "Derler ki sonunda herkes ölecek; bir kurt ile bir kocakarı kalacak. Sonunda onlar güreşecekler. Kocakarı mı kurda galip gelecek, kurt mu kocakarıya onu bilemem. Onu da böyle derler."

Yukarıda kodlayarak verdiğimiz kıyamet konulu efsanelerde, Azerbaycan anlatısı hariç, değişmeyen iki unsur yer almaktadır. Bunlardan biri kurt, diğeri ise yaşlı kadındır. Kurt ve kadın motifi Türklerin köken anlatmalarında da yer almaktadır. Bu bakımdan köken ve k1yamet anlatılarında tekrarlanan bu motifler, Türklerin yaşam ve ölüm felsefelerinin bütüncül bir kimliğe sahip olduğunu göstermektedir. Ancak, zaman içinde sosyal çevrede yaşanan değişimlerle yaratılış ve kıyamete ilişkin dünya görüşü bir dönüşüm geçirmiş ve bu dönüşüm sözlü kültüre yansımıştır. Türkler İslam dinini benimsedikten sonra İslam kültüründeki kıyamet anlayışını içselleştirmişlerdir. Daha eski dönemlerden kalmış olduğunu düşündüğümüz kurtla kıyamete kalmak anlayışı ise, ya unutulmuş ya da ana motifleri yerinde durmakla birlikte söylem bakımından İslami bir kimliğe bürünmüştür. Bir sonraki aşamada ise, deyimleşerek ilenme amaçlı bir söze dönüşmüş, hem konu hem de şekil ve yapı bakımından başkalaşmıştır. Elimizde bu değişim ve dönüşümün ne zaman gerçekleştiğiyle ilgili bir veri bulunmamaktadır. Çalışmamızda yer verdiğimiz anlatmalar ise, 21. yüzyılda az sayıda sözlü kaynaktan elde edilerek yazıya geçirilmiş metinlerdir. Dolayısıyla bu incelemede artzamanlı bir analiz yapmak mümkün olmayacaktır. Biz bu incelemede elimizdeki eş metinleri farklılık ve benzerlikleri bakımından karşılaştırıp bu anlatmaların nasıl farklı bir söyleme evrildiklerini tartışacağız.

Türkiye ve İran'daki sözlü kaynaklardan derlenen altı, Azerbaycan'da anlatıldığı belirtilen ve elektronik kaynaktan elde edilen bir anlatma olmak üzere, kıyamet konulu yedi eş metni, içinde barındırdığı unsurlar ve söylem tarzı bakımından şöyle karşılaştırmak mümkündür. 
A. Anlatıların içerisinde yer alan unsurlar bakımından karşılaştırılması:

1. Anlatılarda, Azerbaycan anlatısı hariç, kurt ve yaşlı kadın motifi yer alır. Azerbaycan anlatmasında yalnızca kurt yer almaktadır.

2. K. ve Y. anlatılarında kıyamet gününde kurdun yaşlı kadını yiyeceği anlatılmaktadır.

3. A. anlatısında kıyamet koptuktan sonra yalnızca bir kurdun hayatta kalacağı, esen kuvvetli rüzgârla önce tüylerinin döküleceği, sonra etlerinin lime lime dağılacağı; ancak kurdun son ana kadar direneceği belirtilmektedir.

4. H1, H2, H3. ve H4. anlatmalarında diğerlerinden farklı olarak kıyamette yaşlı kadın ve kurdun güreşeceği söylenir. Bu güreşin sonunda kurdun galip gelmesi halinde her şeyin yok olacağı, kadının galip gelmesi durumunda ise, dünyada hayatın devam edeceği belirtilmektedir.

5. K., Y., A., H1. ve H3. anlatmalarında İslamî motifler (Allah, Azrail, Sûr, çeşitli kıyamet alametleri gibi) yer almaktadir.

6. H1, H2. ve H4. anlatmalarında kadının kurdu yenmesi olasılığından hareketle yeniden yaratılış motifi yer almaktadır.

7. H3. anlatısında, öteki anlatılardan farklı olarak, kıyametin kopması durumunda dünyanın sularla kaplanacağı belirtilmektedir.

\begin{tabular}{|l|l|l|l|l|l|l|l|}
\hline \multirow{3}{*}{$\begin{array}{l}\text { Anlatılarda yer alan } \\
\text { unsurlar }\end{array}$} & \multicolumn{7}{|c|}{ Eş metinler } \\
\cline { 2 - 9 } & Kayseri & Yozgat & Azerbaycan & $\begin{array}{l}\text { Halhal } \\
\mathbf{1}\end{array}$ & $\begin{array}{l}\text { Halhal } \\
\mathbf{2}\end{array}$ & $\begin{array}{l}\text { Halhal } \\
\mathbf{3}\end{array}$ & $\begin{array}{l}\text { Halhal } \\
\mathbf{4}\end{array}$ \\
\hline Yaşı kadın & $\checkmark$ & $\checkmark$ & $X$ & $\checkmark$ & $\checkmark$ & $\checkmark$ & $\checkmark$ \\
\hline Kurt & $\checkmark$ & $\checkmark$ & $\checkmark$ & $\checkmark$ & $\checkmark$ & $\checkmark$ & $\checkmark$ \\
\hline Kıyamet alametleri & $\checkmark$ & $\checkmark$ & $\checkmark$ & $X$ & $X$ & $\checkmark$ & $X$ \\
\hline Güreş & $X$ & $X$ & $X$ & $\checkmark$ & $\checkmark$ & $\checkmark$ & $\checkmark$ \\
\hline $\begin{array}{l}\text { Kurdun kadını yemesi/ } \\
\text { yıkması olasılığı }\end{array}$ & $\checkmark$ & $\checkmark$ & $X$ & $\checkmark$ & $\checkmark$ & $\checkmark$ & $\checkmark$ \\
\hline $\begin{array}{l}\text { Kadının galibiyet } \\
\text { olasılığı }\end{array}$ & $X$ & $X$ & $X$ & $\checkmark$ & $\checkmark$ & $X$ & $\checkmark$ \\
\hline
\end{tabular}

\section{B. Anlatıların söylem tarzı bakımından karşılaştırılması:}

1. K. anlatısında çekirdekte yer alan kurt ve kadın motifleri bir daire biçiminde bütünlük arz ederek verilmiş; ancak Azrail'in kurdun canını alması ifadesiyle İslami söyleme ait bir başka büyük daire ile çevrilmiştir.

2. Y. ve A. anlatılarında Sûr'un üflenmesinden başlayarak devam eden geleneksel İslami bir kıyamet anlayışı hâkimken, Y.'de yaşlı kadın ve kurt, A.'da ise hayatta kalıp son ana kadar direnen kurt motifi, İslami kıyamet anlayışına eklemlenmiştir. 
3. H1, H2 ve H4. anlatılarında çekirdekte bir daire biçiminde bütünlük arz eden kocakarı ve kurdun güreşme motifi, etrafında ise kıyamet ya da yeniden doğuş kavramlarına gönderme yapan anlatı dairesi vardır.

4. H3.'te merkezdeki anlatı dairesinde kocakarı ve kurt bulunmakla birlikte, güreşin sonunda kurdun kadını yemesi olasılığından söz edilir. Bu söylemi çevreleyen büyük dairede ise, mahşer günü ile İslami anlayışa bir gönderme yapılsa da anlatının sonunda bütün dünyayı kaplayacak olan sulardan bahsedilmesi itibariyle bize Altay yaratılış destanlarındaki sularla kaplı dünya motifini de hatırlatmaktadır (İnan, s. 14.).

5. H2, H3. ve H4.'te anlatıcılar "biz böyle duyduk", “derler ki”, "eskiler bu sözleri derler" gibi ifadelerle gelenekte bu anlatıların var olduğunu belirtmekte, bu bağlamda metinlerarası bir gönderme yapmaktadırlar.

6. Öteki anlatmalarla karşılaştırıldığında H1, H2. ve H4. anlatmalarında yer alan güreş motifine bağlı olarak kadının galip gelmesi durumunda hayatın yeniden yeşereceği, kurdun galip gelmesi durumunda ise kıyametin kopacağ man vurgulanmıştır ki bu da ancak sözlü kültüre özgü bir söylemdir (İlhan, 2018: 170).

Yukarıdaki izahlardan sonra, kurt ile kıyamete kalmak anlatılarını konu ve söylem bakımından üç grupta ele almanın mümkün olduğunu düşünmekteyiz. İlk grup; A, Y. ve K. anlatılarından oluşmaktadır. Bu anlatılarda gerçekleşmesi olası bir kıyametten, tek bir sondan bahsedilmektedir. Y. ve K. anlatısında, kurdun kadını yemesinden sonra dünyanın sonu gelir; A. anlatısında ise, bozkurt son ana kadar dirense de kıyamete gerçekleşir. Bu ilk grup anlatılarında tek yönlü, Eliade'nin tabiriyle söyleyecek olursak, çizgisel ve geriye dönüşü olmayan bir sondan bahsedilmektedir (Eliade; 2001 s. 86.). Tarihi bağlamda Yahudilik, Hıristiyanlık ve hatta İslami kıyamet inancında tek bir sondan bahsedebiliriz. Bu inançlarda kıyametten sonra bu dünyanın yenileneceği ya da tekrar yaratılacağı hakkında herhangi bir ifade yer almaz. Söz konusu inançlarda kıyamet sonrası cennet tasavvuru yer alır ki bu cennet de bu dünyanın dışında bambaşka bir âlemi işaret eder. İncelediğimiz efsaneleri yaratım ve aktarım bağlamında değerlendirecek olursak, daha çok yazılı kültür ya da yazılı kültürle etkileşim halindeki ortamlarda kullanılan tek ve geriye dönülemez bir çizgi halinde ilerleyen anlatmalarla karşı karşıya olduğumuzu söyleyebiliriz. Böylesi anlatmalarda zaman ileriye doğru tek bir çizgide ilerler ve zamanın döngüselliği, yani bitiş ve başlangıçların birbirini izlediği düşüncesi görülmez.

İkinci grup olarak değerlendirdiğimiz H1, H2, ve H4. anlatılarında son ve başlangıç bir aradadır. Şöyle ki kurt ile kadının güreşmeleri sonucunda kurt galip gelirse, dünyanın sonu gelecek; fakat kadının galip gelmesi halinde dünyada yeniden yaşam olacaktır. Bu anlatmalarda yine Eliade'nin deyişiyle "sonsuz geriye dönüş" ya da "çevrimsel görüş" hâkimdir. Örnek olarak; kuzey ve güney Amerika'daki kıyamet anlatılarında bazen yaşanan felaketin yeni bir yaratılışla sonlanacağı bazen de kıyamet kopmadan yaşanacak olan evrensel bir yeniden canlanmadan söz edilmektedir (Eliade; 2001 s. 81). Bu anlatmalarda olduğu gibi, Halhal anlatma- 
larında kıyamet ve yeniden canlanma/yeniden doğuş motifleri bir aradadır. Dolayısıyla, bu üç anlatmadaki sonuç motifinin dairesel zaman anlayışılla uyumlu olduğunu söylemek mümkündür. Ayrıca, yaratım ve aktarım bağlamında ele aldığımızda, yeniden canlanmaya yapılan vurgu, anlatıların söylem bakımından sözlü geleneğe bağlılığını ortaya koymaktadır (İlhan, 2018: 170-171). Şöyle ki sözlü kültür geleneğinin hâkim olduğu anlatmalarda zaman algısının daha çok döngüsel olduğu ve tek yönlü zaman anlayışından farklı olduğu bilinmektedir.

Üçüncü grupta, H3 anlatısı yer almaktadır. Bu anlatma, içerisinde bulundurduğu motifler ve söylemi bakımından, ilk grup ile ikinci grup arasında bir geçiş fonksiyonu üstlenmektedir. Şöyle ki H3'te anlatıcı kadın ve kurdun güreşeceğini belirttikten sonra Hangisi ötekini yıkar$s a . .$. ifadesi ile kıyamete yönelik kesinlikten uzaklaşır. Ancak hemen ardından kurdun kadını yenmesi olasılığını anlatır. Tamamlanacak olan bir kıyameti vurgular. Bir başka deyişle, kurdun kadını yemesi durumunda mahşer olacağını, toprakların döküleceğini, dağların uçacağını, yerin dümdüz olacağını ve her yerin sularla kaplanacağını belirtir. Görüldüğü üzere bu anlatıda, anlatıcı kadının kurdu yenme ihtimalini geri plana atmıştır. Dolayısıyla, H3 anlatısı söylem bakımından; döngüsel zamanı yansıtan H1, H2. ve H4. Anlatıları ve düz bir zaman algısını yansıtan K, Y. ve A. anlatıları arasında bir yerde konumlandırılabilir.

Görüldüğü üzere, anlatı metinleri gerek içerisinde yer alan unsurlar gerekse söylemleri bakımından farklılaşmışlardır. Bu farklılaşmanın anlatıları, sözlü kültür içerisinde şimdilik tespit edemediğimiz bir zaman diliminde, yeni bir yapı ve işlevle karşımıza çıkardığını söylememiz mümkündür. Bu anlatmalar günümüzde, beddua amacıyla kullanılan bir deyime dönüşmüştür. Kurt ile klyamete kalmak deyimi bu bakımdan bir çözümlemeye ihtiyaç duymaktadir.

\section{Kurt ile kıyamete kalmak deyiminin günümüz sözlü kültüründeki kullanımının çözümlenmesi}

Kayseri, Yozgat ve Halhal şehirlerinden derlenerek yazıya aktarılan "kurt ile kıyamete kalmak" deyimi bu yörelerde daha çok ilenme veya alay etme niyetiyle kullanılmaktadır. Yörelere göre söylenişi şöyledir;

K. "Allah, Bozkurtunan kıyamete kalasın!"

Y. “Ölmedi gitti, kurtla kıyamete mi kalacak ne?"

H. "Kurdunan kiyamete kalacak./Kurdunan kiyamete kalacaksan?"

Bu deyim, Yozgat ve Halhal yörelerinde gelinlerin çok uzun yaşayan kayınvalideleri için beddua ya da alay etme amaçlı kullandıkları ifadelerde yer almaktadır. Kayseri yöresinde de beddua amaçlı kullanılmasına rağmen, bu bedduanın kimler tarafından kimi işaret edilerek kullanıldığı alıntıladığımız kaynakta belirtilmemiştir. Ancak, her üç yöredeki ifadenin ilenme ya da alay niteliği taşıdığı açıktır.

Bizim bu ifadelerle ilgili temel sorgulamamız, alay amaçlı kullanılan "kurt ile kıyamete kalacak" kalıbının Türk kültüründe kadın ve kurt gibi kutsal motiflerin yer aldığı kıyamet anlatısından sıyrılarak nasıl ve hangi biçimde başkalaşmış olduğudur. Bir önceki bölümde, 
elimizde bulunan eş metinlerini ayrıntılı bir biçimde karşılaştırdığımız kıyamet anlatıları, sözlü kültürde adeta unutulmaya yüz tutmuştur. Ancak, kurt ile kıyamete kalmak deyimi daha canlı bir şekilde kullanılmaktadır. Bu nedenle, incelememizin bu bölümünde, yine sözlü kaynaklardan derlenerek yazıya aktarılan kurt ile klyamete kalmak deyimi şekil ve yapı, konu, işlev, anlatıcı ve dinleyici bağlamında ele alınacaktır.

Elimizde yedi eş metni bulunan kurt ve kadın konulu anlatılar tür olarak birer efsanedir. Ancak, kurt ile kıyamete kalmak ifadesiyle şekil değişikliğine uğrayarak bir deyim olarak karşımıza çıkmıştır. Bir anlatı metni olarak, sosyal değişimlerin etkisiyle kullanım sıklığı azalan hatta pek çok yerde unutulan bu efsane, bir deyimde donup kalmıştır. Folklor ürünlerinin zaman içerisinde kullanımdan düşme veya unutulma tehlikesi altında bulunduğu koşullarda bir dönüşüme uğrayarak farklı tür ve anlamlarda yaşadığı bilinmektedir (Aktulum, 2013: 29-35). Yine deyimin içerik ve konu bakımından da efsaneden farklılaştığ 1 görülmektedir. Kurt ile kıyamete kalmak deyimi bizim saha araştırmaları yaptığımız Halhal şehrinde çok uzun yaşayan kişiler, özellikle de uzun yaşayan kadınları işaret etmek için kullanılmaktadır. Saha çalışmalarımız sırasında bu deyimle ilgili sorular yönelttiğimiz 50 kişiden 10’u bu ifadeyi hiç bilmediğini, 36 kişi deyimin çok uzun ömür süren kişiler için kullanıldığını belirtmiştir; kaynak kişilerden yalnızca 4'ü bu deyimin kökeninde yukarıda verdiğimiz kıyamet konulu efsaneler olduğunu anlatmıştır. Deyimler, daha çok genç nesil, özellikle de gelinler, kızlar tarafından kayın valideleri ya da bir akrabaları için kullanılmakta, günlük konuşma diliyle ifade edilmektedir. Bu deyimin yer aldığı söylem içerisindeki fonksiyonu ise, efsane metinlerinden farklı olarak uzun yaşayan kadının ve kıyamete kadar ayakta kalacağı varsayılan kurdun olumsuzlanarak verilmesidir. Dolayısıyla kurt ve kadın gibi Türk mitolojisinde kutsal kabul edilen değerler altüst edilmek suretiyle kurt ile kıyamete kalmak ifadesi, sözlü kültür içinde yaşamaya devam etmektedir. Bauman'ın “yeniden bağlamlaştırma” olarak adlandırdığı, bazı türlerin yeni icralarında içerik ve işlev bakımından değişmesi söz konusudur. Bauman, bu konuyla ilgili “... yeniden bağlamlaştırma metnin yeniden çözümlenmesi demektir, onun edimsel gücündeki ve sözünün etkisindeki bir kayma neyi hesaba kattığı ve ne içerdiği ile ilgilidir” şeklinde bir açıklama yapmaktadır (Bauman, 2008: 117). Bu yolla eski Türk inançları ve köken anlatmalarıyla bütünlük arz eden kurtla kıyamete kalma efsanesinin, sözlü kültürdeki farklı icralarında yeni metinlere dönüştüğünü, anlatıcılar tarafından bazı eklemeler ve çıkarmalar yapılmak suretiyle gelenekte var olduğunu görmekteyiz. Bir sonraki aşamada, yani deyimleşme aşamasında ise, daha sık hatırlanıp kullanıldığını, bu yolla Türklerin günümüzdeki inançlarının gölgesinde kalıp unutulmaktan kurtulduğunu; ancak yapı, içerik, işlev ve bağlam bakımından bir dönüşüme uğradığını söyleyebiliriz.

\section{Sonuç}

İncelememizde ele aldığımız Türk kıyamet efsanesinin, tespit edebildiğimiz yedi eş metni bulunmaktadır. Bunlar; bizim İran'ın Halhal şehrinden derlediğimiz dört eş metni bulunan anlatma, Harun Güngör'ün Kayseri'nin Üzerlik köyünden derlediği anlatma, Öcal Oğuz’un Yozgat'tan derlediği anlatma ve aynı araştırmacının internet kaynağından incelemesine al- 
dığg1 Azerbaycan anlatmasıdır. Bu efsanelerin yanı sıra günümüz Türk sözlü geleneğinde yaşayan kurt ile kıyamete kalmak deyimi ve bu deyime bağlı ifadeler ise, Harun Güngör, Öcal Oğuz ve tarafımızca tespit edilmiştir. Tespit edilen bu deyim ve etrafında şekillenen ifadeler, daha çok gençler ya da gelinler tarafından uzun ömür süren yaşlı kimseler veya kayınvalideleri için ilenme veya alay amaçlı kullanılmaktadır.

Kurt ile kıyamete kalmak efsanesinin zaman içerisinde halkın düşünce dünyasında yerini kaybettiği, ancak sözlü geleneğin ve eski inançların kuvvetli olduğu yerlerde eş metinler halinde yaşadığını söyleyebiliriz. Bu noktada donup kalma ve unutulma gibi bir süreçle karşılaşan kurt ile kıyamete kalmak anlatısı, adeta kabuk değiştirmek suretiyle beddua amaçlı kullanılan bir deyime dönüşmüştür. Dolayısıyla bilinirliği daha yaygın olan kurt ile kıyamete kalmak deyiminde, eski Türk inançlarında yer alan kurt ve kadının kutsallığı tersine çevrilmiştir. Yani kadın da kurt da olumsuz figürler olarak kıyamete kalacak lanetliler gibi aktarılmaktadır. Buraya kadar genel hatlarıyla ifade etmeye çalıştı̆̆ımız kıyamet anlatıları ve bu anlatıların olumsuz anlamlı bir deyime dönüşme sürecini ayrıntılarıyla şöyle sıralayabiliriz;

1. Elimizde bulunan sözlü kaynaklara dayanan metinlerin azlığından hareketle kurtla kıyamete kalmak anlatmasının gelenek içinde oldukça zayıfladığını söyleyebiliriz.

2. İncelememize konu ettiğimiz eş metinleri üç grupta ele almak mümkün olmuştur. Birinci grup; Kayseri, Yozgat ve Azerbaycan, ikinci grup; Halhal'dan derlenen 1, 2 ve 4 numaralı anlatılardan, üçüncü grup ise Halhal'a ait 3 numaralı anlatıdan oluşmaktadir.

3. İlk grupta yer alan Kayseri, Yozgat ve Azerbaycan anlatmaları kesin bir bitiş veya kıyamet görüşünü ortaya koymaktadır. Bu anlatılardaki zaman algısı tek bir çizgi üzerinde ilerlemekte ve bu yönüyle anlatmalar yazılı kültürün zaman algısını yansitmaktadir.

4. İkinci grupta yer alan H1, H2. ve H4. anlatmalarında, kesin bir bitiş değil, döngüsel bir süreç söz konudur. İkinci gruptaki anlatılarda görülen döngüsel zaman, bu anlat1ların sözlü kültür geleneğine sıkı sıkıya bağlı olduklarını göstermektedir.

5. H3 anlatması, güreş motifini içermekle birlikte kurdun kadını yeneceği ihtimaline ağırlık vermekte ve kesin bir kıyametten söz etmektedir. Şöyle ki bu anlatıda döngüsel bir son sezdirilmiş; ancak anlatıcı döngüsel olmayan, kesin kıyamet tasavvuruna meyletmiştir denilebilir. Bu yönüyle H3 anlatması, birinci ve ikinci grup arasında bir geçiş görevi üstlenmektedir.

6. Zaman içinde, Türklerin inanç yapılarındaki değişimler ve çeşitli sosyal değişiklikler itibariyle donup kalma, unutulma noktasına gelen kıyamet anlatısı, gelenek doğrultusunda konu ve yapı bakımından dönüşüme uğramış ve kurt ile kıyamete kalmak deyimiyle sözlü kültürde yaşamaya devam etmiştir.

7. Köken mitlerinde olduğu gibi kıyamet konulu efsanelerde de kutsal kaynaklı olan kadın ve kurt motifleri, kurt ile kıyamete kalmak deyiminin sözlü kültürdeki izahlarında kutsallığın dışına itilmiş, yergi amaçlı bir anlam çerçevesine oturtulmuştur. 
İşbu açıklamalardan bir çıkarım yapacak olursak, yazılı metinlerde kurt ile kıyamete kalmak efsanesine rastlanmasa da, Türk sözlü geleneğinde köken mitleriyle paralel bir kıyamet anlatısının varlığı kesindir, diyebiliriz. Söylemlerarasılık/metinlerarasılık bağlamında değerlendirildiğinde sözlü gelenekte derin kökleri olan anlatmalardan biri olduğunu düşündüğümüz Türk kıyamet tasavvurunun, günümüzde başkalaşıma uğramış bir biçimde yaşadığını görmekteyiz. Kıyamet konulu anlatmalarda aynen köken mitlerindeki gibi olan kadın ve kurt motifleri, Türk inançlarındaki belirli bir kutsallığı yansıtmaktadır. Zaman içerisinde inanç bağlamında kültür dünyamızdan uzaklaşmaya başlayan kurt ve kadın algısı, sözlü kültürde yaşayan kurt ile kıyamete kalmak deyiminde tamamen olumsuz bir karaktere bürünmüştür. Ancak, burada anlam ve söylem bakımından gerçekleşen olumsuz durum, kurt ve kadına dair kıyamet söyleminin gelenekten silinip gitmesini engellemiştir. Bu bağlamda kurt ile kıyamete kalmak, bir deyim olarak sözlü kültürümüzdeki yolculuğuna devam etmektedir.

\section{Notlar}

1 Köken mitleriyle ilgili geniş bilgi için bk. Bahaeddin Ögel. Türk mitolojisi-I. Ankara: TTK, 2014, ss. 21-33.

2 Bu incelemede İran'dan derlediğimiz kıyamet anlatıları, içinde yer alan motifler bakımından incelenmiş ve bu anlatıların Türk köken mitleriyle bağlantısı üzerinde durulmuştur.

\section{Kaynaklar}

Aktulum, K. (2013). Folklor ve metinlerarasılık. Konya: Çizgi.

Bauman, R. (2008). Tür, performans ve metinlerarasılığın üretimi. I. Altun (Çev.). Milli Folklor, S. 78, ss. 114-122. Ankara: Geleneksel.

Eliade, M. (2001). Mitlerin özellikleri. S. Rifat (Çev.). İstanbul: Om.

Gülmez, G. (2010). Kurt ile kıyamete kalmak deyiminin eskatolojik arka planına dair yeni bir anlatma ve düşündürdükleri. II. Uluslararası Türk Dünyası Kültür Kurultayı, Çeşme, (Bu bildiriler yayımlanmamıştır.)

Güngör, H. (1998). Üzerlik köyünde hayvanlarla ilgili inançlar. Prof. Dr. Dursun Yıldırım Armağanı, ss. 62-65. Ankara: Türkiye Diyanet Vakfi.

Karini, G. (2012). İran-halhal yöresi Türklerinin efsaneleri üzerine bir araştırma. Ege Üniversitesi, Sosyal Bilimler Enstitüsü, Yayımlanmamış Doktor Tezi, İzmir.

İlhan, M. E. (2018). Kültürel bellek sözlü kültürden yazılı kültüre hatırlama. Ankara: Doğu Batı. İnan, A. (1986). Tarihte ve bugün şamanizm materyaller ve araştırmalar, III. Baskı, Ankara: TTK.

Oğuz, Ö. (2009). Kul Himmet ve sözlü gelenek tanıklığında kozmogonik mitin eskatolojik serüveni. Milli Folklor, S. 84. Kış, ss. 51-56. Ankara: Geleneksel.

Ögel, B. (2014). Türk mitolojisi-I, Ankara: TTK. 
folk/ed. Derg, 2020; 26(4):827-838

DOI: $10.22559 /$ folklor.1350

\title{
The Heroes Crossing the Line: An Evaluation of Making Enemies in Turkic Epics
}

\author{
Çizgiyi Aşan Kahramanlar:Türk Destanlarında Düşman \\ Yaratma Eylemi Üzerine Bir Değerlendirme
}

Mustafa Duman*

\begin{abstract}
This study investigates the origins of making an enemy through examples taken from Turkic epics, and offered personal evaluations on the relationship between epics and real world politics. In order to make a comprehensive evaluation, 30 epic texts selected from different regions of the Turkic world constitute the scope of this study. The similar features of the enemy in these epics were determined through a structuralist analysis. However, the epics included in the present study are merely some containing typical examples of enemy-making: the epic of Oguz Kagan, the epic of Koroghlu (Anatolian version), Manas and Kocacas epics of Kyrgyz, the epic of Koblan Batir of Bashkirs and the Book of Dede Korkut. By analyzing the epics from different perspectives, the aim was to put forward a classification of the enemies in the epic stories. It was also aimed to contribute to the knowledge of better understanding of the causes of the conflict and the relationship between politics and epics as well as their influences upon one another.
\end{abstract}

Keywords: making enemy, marginalization, politics, the hero, Turkic epics

Geliş tarihi (Received): 17.06.2020- Kabul tarihi (Accepted): 10.08.2020

* Dr., Uşak Üniversitesi Fen Edebiyat Fakültesi Türk Dili ve Edebiyatı Bölümü, Türk Halk Bilimi ABD. m.duman66@gmail.com. ORCID 0000-0001-9689-40340 


\section{$\ddot{O} \mathbf{z}$}

Türk dünyası destanları örnekleminde "düşman yaratma” eyleminin kökenlerinin odak noktası olarak belirlendiği bu çalışma, kurgusal dünyadaki düşman yaratma eylemi ile gerçek dünyadaki örnekleri arasındaki ilişki hakkında değerlendirmeler içermektedir. Geniş kapsamlı bir inceleme ortaya koymak için Türk dünyasının çeşitli bölgelerinden 30 destan yapısalcı bir bakış açısıyla incelenmiş ve bu destanlardaki düşman tiplerin ortak özellikleri belirlenmiştir. Tüm örneklere makale içerinde yer vermek mümkün olmadığı için bir seçki yapılmıştır. İncelenen destanlardan düşman yaratmaya dair en tipik örnekleri barındıran; Oğuz Kağan Destanı (Uygur harfli nüsha), Anadolu sahası Köroğlu Destanı (Behçet Mahir varyantı), Kırgızların Manas ve Kocacaş destanları, Başkurtların Koblan Batır Destanı ve Türk dünyasının ortak destanı olarak kabul edilen Dede Korkut Kitabı'ndan örneklere makale içerisinde yer verilmiştir. Türk destanlarını farklı bir bakış açısıyla inceleyerek bir düşman tasnifi ortaya koymak, çatışma olgusunun temellerini daha iyi anlamak, kurgusal dünya ve gerçek hayattaki çatışmanın kökenleri hakkında özgün görüşler sunmak ve bu iki farklı dünyanın birbiri üzerindeki etkilerini değerlendirmek amaçlanmıştır.

Anahtar sözcükler: düşman yaratmak, ötekileştirme, siyaset, kahraman, Türk destanlart

Son, the enemy is he whom we kill when we can, and, if they are able, they kill us.

(The Book of Dede Korkut)

\section{Introduction}

In the creation myths of Turks and many other societies, there is primarily chaos and then cosmos. The meaning of the cosmos here is the existence of a functioning order within itself, and the absence of anyone who rebels against the order. Therefore, all characters that disrupt this order are considered evil. In Turkish mythology, one of the most typical examples of these evil characters is Erlik (trickster, demon). Also, Eje, Törüngey and other characters who have a role in the violation of the forbidden are considered negative characters because they have a share in the disruption of the order. The most important point here is that while the cosmos represents a pure and unquestionable order, the characters that break that order were created in the cosmos itself. In other words, the characters that cause chaos are actually children of the cosmos. Thus, the existence of free-will necessary to rebel against the order of the cosmos is an inherent part of it, and therefore evil behavior must be considered a natural variation of the cosmic order.

This fictive world continues to exist in epics after the creation myths with the emergence of an epic hero acting as a representative or guard of cosmic order. For this reason, whatever the epic hero does, their actions - whether or not these actions follow or contradict contemporary universal ethical rules - are unquestionably considered necessary and thus positive. Consider that basic perspective in the epic world is that the cosmos persists independently of ethical 
analysis by those who share its creation. Thus, the actions of the hero - the guardian created by the cosmos in the perseverance of its natural order - naturally must also persevere independently of ethical analysis. However, this gives rise to an interesting phenomenon occurring in the mythological world as well as the real world. Specifically, the actions of the hero also serve to create a new enemy.

Moreover, mythical understandings such as these do not only appear in epics, but also in the real-world civil order of the Turks throughout history. One example of this is the cultural belief that the blood of the Khan is holy. Effectively, this cultural mythical thought was grounds for not questioning the actions of those with noble blood in Turkish culture. This also provides context for the real-world order influencing the creation of epics, as there have been some epics created under influence of the khans (the kings) throughout history. This was likely done with the intention of strengthening public belief in divine regard for the khan. This is an example of the argument that there is a circular relationship between the mythical thought which is reflected in literary works and that which influences everyday life: real life shapes literary works, literary works shape real life.

This brief perspective on mythical thought, imbued from epics and reality, is essential in order to trace the influences of thoughts and actions associated with people's perception of enemies and evil, and the impact they have on the world, and is the basic foundation of the present study. For this reason, the epic-reality relationship needs to be sampled and analyzed. This study is being carried out in order to investigate the dynamics of the interactions among epics, creation of enemies, and politics. Therefore, the study first deals with the unquestionableness of the epic hero's actions and then the types of enemies that emerged at the conclusion of these unquestionable actions of the epic hero.

\section{Why are epic heroes always good?}

The thought process in the creation of an epic, unconditionally considers the hero's actions as positive and necessary. Within the texts, however, certain justifications are provided to allow negative actions by the hero. One such justification is the attribution of sacredness to the hero. The hero's belonging to a noble family, or the hero's close relationship with the gods, is a demonstration of his divineness in the epics, and immunity from ethical judgment. This common hero design does not only appear in Turkic epics but also in the epics from the Western world and in epics throughout Asian history as well. ${ }^{1}$ It is known that in the epics such as Gilgamesh, Mahabharata, and Shahnama the hero has sacred or divine characteristics such as the hero in the Epic of Oguz Kagan. There are, of course, textual necessities in designing a sacred hero, such as fighting characters with extraordinary traits and enemies from other worlds. However, the concept of the hero as sacred and divine is also nothing more than a reflection of a strong king or important leader in real life. Hence, it is a strong possibility that the perception of a sacred king in people's minds has spread to many epics. This leads to the fact that the actions of the epic hero are not to be questioned because the hero is sacred. A couple concrete examples of this phenomenon are exemplified in stories 
about Ancient Egyptian pharaohs, and even the today's North Korean leaders being regarded by their people as divine in nature.

Secondly, the fact that the hero is formed as a source of absolute goodness and that his actions are not questionable is also related to the non-objective style of the epic narrator who regards the hero as the center point (the source of absolute goodness) of the epic. The dialogue between Joseph Campbell and Bill Moyers in The Power of Myth (2013) directly supports the idea of the narrator's non-objective attitude. In the interview, Moyers wonders what the "hero" means, and questions whether Napoleon is a hero or a cruel leader. As an answer to this question, Campbell states that he is a hero for his people but an enemy for the people he invades. According to Campbell, in determining whether someone is a hero or an enemy, it is the determinant of where the focus of our consciousness is located (Campbell et al. 2013: 167-168). The subjective attitude in forming of epics determines the hero as the center of focus within the consciousness. Thus, the audience or reader facing a biased text does not attempt to question the hero's actions.

The relationship between epics and real life also forms a basis for the hero's actions not to be questioned. Although epics are considered as romantic texts containing fantastic elements, they are realistic at the same time. This realism manifests itself not in the way the themes are presented within the epics, but in the way that epics reflect the general acceptable behavior and everyday-life of the society. In other words, the events which occurred in an epic's plot may have extraordinary characteristics but these extraordinary events are due to the exaggeration of events in real life. This can be exemplified by the looting tradition among the Turks: the looting activities, which are frequently presented in Turkic epics, are not just an action that appears in the fictional world. Among Turks, the looting activities in question in the real world were performed in two ways: 1. Booty sharing after a battle and, 2. Khan's (or rich people's) willingly being looted of their own goods by people (potlaç, kençliyü) (Duymaz, 2005: 37-60). ${ }^{2}$ The looting tradition can be seen either in a realistic way or, adorned with extraordinary features in Turkic epics. Therefore, the looting tradition, which was a cultural element in the lifestyle of the Turks, is presented as an ordinary act in the epics. For this reason, it is not open to discussion that heroes' looting activities could be considered evil behavior by the narrator and audience.

Besides the contextual reasons as an answer to the question "why is the epic hero always good?", there are substantial textual creation circumstances which (by natural course are required to make the hero absolute good) are as important as the contextual reasons. One such reason is the character types of the epics. These character types are commonly referred to as flat characters and their actions comprise almost all of the content in epics and other folk narratives. Since flat characters are two-dimensional characters, they represent either good disposition or the evil one (those used as background characters have generally a neutral feature). In the era when epics were created and preserved (heroic era), it was very important that the narratives consisted of flat characters in terms of the recallability and the transferability of the text. This system did not lend itself to accommodating such complications, which would also likely not serve the epic's inspirational value. This is the main reason why the 
epics generally do not contain round characters with changeable features. In addition, an epic is composed of narrative patterns (episodes) arranged one after the other, poetic themes, and artistic references, all of which function collectively to support the image of the hero as the representative of goodness. Therefore, even negative actions of the hero are presented with positive affirmation within the flat character framework, and in conjunction with the other epic patterns, to support the hero's image of goodness and promoted immunity to ethical judgment.

The theme and content features of the epics are also one of the reasons why the action of the epic hero is not questioned. It is a common opinion that the period of formation of the epics begins with the emergence of the organized states. It is also the common opinion that epics are representative of the social structures of the time period of their original creation. One common thread throughout history and geographical location is the important ideals within the social circumstances of the time and place which motivated the creation of that epic. Naturally, this will often involve a real-life leader or leaders within a power struggle, viewed by those within, as them fighting against the enemy, and with an ideal outcome from the participants' perspectives. The motivating circumstances of the epic's creation would, therefore, be inspiring by nature and based upon such real-life events and achievements. These events/achievements would then be arranged ideally within the patterns of the epic, resulting in an ideal portrayal of the hero's actions within the narrated epic. This ideal perspective was likely a factor in what motivated the initial creation of the epic, and therefore that idealism will be represented within the patterns of the epic. Hence, the basic theme of epics formed at such a time consists of a leader and his/her achievements that emphasize the national unity. Considering this reality, epics can be accurately regarded as stories of achievements. The alleged opinion here is not that all of the epics are life adventures of the leaders who live in the real world, but whoever the epic hero is, $\mathrm{s} /$ he is a symbol of an ideal associated with real life. This ideal is embodied in the real world as the king (ruler) and in the fictional world as the epic hero. Thus, whether $\mathrm{s} /$ he is a historical personage or not, a hero is presented by being idealized in the epics. ${ }^{3}$ Congruent with the narrator's perspective, it emerges as a natural tendency that the hero's negative actions are not mentioned in the epics.

\section{Making an enemy - politics - timeless story}

Whether art reflects the reality or the ideal is a matter that has been debated since Plato and Aristotle. Instead of re-opening this subject, suffice to say that the relationship between reality and idealization is indistinguishably intricate. Epics are a strong medium for examining this relationship because, on the one hand, epics reflect the lifestyle of the period they were formed; on the other hand, they also undertake the task of idealizing some characters or events in everyday life, and are always confined within the context of perception and perspective, which will eventually become the narrator's perspective. Of course, this task of idealization is not reserved especially for the hero; naturally, it is also applied to the portrayal of the enemy. 
For the idealization of the epic heroes and their actions, an enemy is presented against them. The "classic" enemy, also referred to as "natural enemy" or "old-fashioned enemy", emerges at this point and acts aggressively against the hero with an ideally evil agenda. However, there are still other enemies besides the classical enemy concept mentioned below in the epics. These enemies do not have any negative attitude; on the contrary, it is the actions of the epic's hero which cause them to appear as an enemy. Examining these types of enemies provides an opportunity to see the events from the enemies' perspective. Therefore, under this subheading of the present study, the enemies that are outside the definition of the classical enemy are investigated. In order to clarify these evaluations, certain examples from Turkic epics are utilized. Moreover, through the examples from the historical events and the politics, the intricate relationship between reality and idealization is emphasized. Evaluating events from enemy's point of view, or at least trying to objectively evaluate events, is a futile attempt in terms of construction of the text but this empathy developed with the enemy will provide a better understanding of the process of making an enemy.

\section{Old-fashioned enemy}

In epics, the enemy is simply presented in three steps: showing up, performing hostile acts, and being punished. Therefore, the audience/reader cannot find an opportunity to empathize with the enemy because just as the hero is the source of absolute goodness, the enemy is the source of pure evil. Circumstantially, this is similar to the reality that an individual who grows up within a traditional belief system (or religion) is very unlikely to develop an empathy with the devil because the belief system does not give the individual such an opportunity.

Myths and stories such as the Tree of Knowledge and the Altaic creation myth, can be used to show how concepts such as betrayal lead to separation of oneself as being distinctly different from the other(s) who are the betrayers. This stark difference in perception is theoretically the means by which people identify others as an enemy. This also involves the perception of others as foreign or unlike oneself, and unworthy of trust. In the Tree of Knowledge myth, this is the serpent (Satan), in the Altaic creation myth, it is Erlik (Satan) who is recognized as a source of pure evil only after his first betrayal. It is not to advise one to become more familiar with the devil, as it is to recognize the extension of those who are perceived as different, as presumably being evil due to being foreign. This is exemplified in Richard Kearny's book Strangers, Gods and Monsters, as "evil is alienation, bad is alien" and he states that ever since the early Western world equated goodness with the concepts of "self-identity" and "lightness", evil has often been associated with concepts of foreignness. This prejudice against exteriority has never been shed even in today's world (Kearney, 2012: 87). Due to early perceptions in mythical thinking such as these, the "old-fashioned enemy" design appears in the epics accordingly: an enemy who cannot be understood, empathized with, and is untrustworthy. Moreover, epic creators are aware that they have designed such an enemy. They sometimes transmit their definitions of the enemy to the audience/reader through the characters they create. The dialogue about the enemy between Kazan and his son in the Book of Dede Korkut is a fundamental example for this: 
"The son asked, 'What does enemy mean, Father?'

'Son, the enemy is he whom we kill when we can, and, if they are able, they kill us,' replied Kazan.

Uruz asked, 'Father, if one kills their princes, is one held to account for it?'

'Even if you kill a thousand infidels, no one will ask you a question. But this infidel with a savage religion now puts us in an awkward situation." (Sümer et al. 1991: 73-74; Ergin, 1997: 158).

This dialogue in the Book of Dede Korkut is a summary of the enemy design in the Turkic epics: an enemy whose nature of being good or evil is not questioned, and whose basic motivation is to kill the hero, and therefore must be destroyed. In fact, this perception of common (old-fashioned) enemies is not only in Turkic epics but also in epics belonging to other societies. There are also enemies outside of this classical enemy concept in the Turkic epics which can be classified as follows: those being looted, rebels, and even passive ones.

\section{The victim enemy/ Those being looted}

Booty sharing after a battle is one of the elements related to a war in the Turkic epics. As previously mentioned, in reality, the looting activities in the epics are a reflection of real-life wartime practices of the Turks. Therefore, it is ordinary to see a character whose land or herd of horses is looted by the hero when conceived of as an enemy. Thus, there is a common thread of cultural normalcy between looting in the epics and real-life lootings. Before further evaluations of the issue, it is advantageous to first look closer at some of the looting activities in the Turkic epics:

Koroghlu (Köroğlu) is visited by a dervish (holy man) in the epic of Koroghlu, which is widely known among Turkic communities (Kaplan et al. 1973). After the dervish praises Koroghlu and all his soldiers, he mentions that only Ayvaz, the adopted child of Koroghlu who is also one of his soldiers, is missing something which all the other soldiers have. He is lacking a ciga. Ciga is a feather that only demoiselle cranes have. Koroghlu assigns some of his troops to find a ciga for Ayvaz. The soldiers hunt demoiselle cranes, which are banned to hunt in Baghdad. In response to this, the king of Baghdad commands the capturing of troops hunting birds. A war begins between Koroghlu and the king's army. In brief, the war ends up against the king of Baghdad.

As it can be seen from the example, the king of Baghdad, at first, does not have a bad attitude against Koroghlu. On the contrary, the hero causes the war to begin by poaching (a form of looting) the birds in the king's country. The hero thus makes an enemy. However, the narrator takes on another task at this point: legitimizing the king as an enemy. In doing this, the narrator adds some extra information that the king is trying to win this war by employing underhanded tactics, such as violating peace contracts. Without this evil behavior, the king is doing nothing more than his kingly duties of enforcing the law of the kingdom. As such, this serves to legitimize the king's character as an enemy. In a different chapter of the same epic, Koroghlu and his friend Kiziroghlu fight against Georgia and Afghanistan kings because of similar looting activities. Besides the looting in the epic of Koroghlu, in the epic of Manas of Kyrgyz, it is seen that Manas, after becoming a hero, lands troops on against the Kitays (a Mongolian tribe), the Calmucks, and other communities and seizes women and goods 
from them (Yıldız, 1995; Koenalıyev et al. 2017). Similarly, in the epic of Koblan Batir of Bashkir, after Koblan beats Kazan Khan, an unnamed khan is looted of a herd of horses merely because Koblan's friend, Karaman, encourages Koblan to do so on their journey back to their country (Suleymanov et al. 1994).

The looting of the conquered country among Turks is regarded by many researchers as a kind of "war reparations". This has been one of the major incomes in the economic life of nomadic societies. ${ }^{4}$ Therefore, the looting activities in the Turkic epics should be regarded as a fictive reflection of real life, and justification for acceptability by heroes.

These examples and evaluations about the looting in the Turkic epics are not, in fact, far from the realities of today's world. Looting is obviously regarded as a primitive or barbarous behavior that contradicts the contemporary ethical values of today's world. However, although the above assessments and examples about looting have been made in the context of the Turkic epics, it is justifiable to claim that today's modern man also has a hypocritical attitude towards looting. It is common knowledge that many of the wars in today's world result in the victor's control of valuable natural resources. However, the victor of the war does not admit that the purpose of this war is looting. Instead, the victor draws attention to the different causes of the war through media reports and movies, which one could even consider the epic texts of the modern day. The only difference between the epics of yore and the present day's epics (media) is that while the looting is a normal action in the epic poetry, the contemporary media attributes propagandist reasons for the waging of wars in order to control natural resources. When analogizing the media as a form of modern day epics, it is noteworthy that they also serve some of the same traditional purposes; creating enemies, supporting heroes, and in doing so, continue blurring the line between reality and fiction. Therefore, the evaluation of the process of normalization of the looting made in the sample of Turkic epics emphasizes that the facts of today's world should be looked at from a different point of view.

\section{Rebels/ Obey or die}

One of the most important reasons for a war in the epics is the disobeying of the hero. The epic hero expects an unconditional obedience from those living under his protection, and those in surrounding states, and punishes those who do not obey him. In the epic of Oguz Kagan (Oğuz Kağan) the words of Oguz are like the manifesto of the epic hero demanding unconditional obedience:

"I am an Uyghur king, and I must be king of the world's four corners. I expect you all to obey. If anyone obeys my orders, accepting his gifts I will regard him as an ally. If anyone does not, I will become wrathful to him; regarding him as an enemy I will land troops on his country; carrying out a raid, I will have him hanged and destroyed." (Bang et al. 1936: 7). ${ }^{5}$

Oguz Kagan regards the Uyghur state as the center of the world and himself as the leader of the world. Therefore, anyone who does not obey him in his hegemony must be punished because they are rebels. In the present epic, Altun Kagan and Uruz Kagan are saved from Oguz's wrath because they obey him but Urum Kagan does not obey him and he is punished. There is a gray wolf, a divine being that guides Oguz during the wars he has made, which emphasizes the sanctity of the actions of Oguz. This sacred being should be accepted as a 
symbol that legitimizes the struggle of Oguz. Similarly, in the epic of Manas, Kurk Coro (forty of the soldiers), Alman Bet, and Acıbay are killed because they do not want to serve and obey Manas's son Semetey, after Manas died (Y1ld1z, 1995).

It is clear that the epics are narratives emphasizing the national integrity. The most important way of ensuring national unity was the construction of an authoritarian regime at the time when epics are first formed. The authoritarian regime is in need of unconditional obedience. It is an undeniable fact that the countries that have an authoritarian regime in whatever form of government, even today, have a similar political tendency. This authoritarian perspective has not changed since the first days when such states existed. Dolkun Kamberi's opinion about Oguz Kagan's manifesto is noteworthy on this point: "Back then, every strong leader had the same foreign policy: expand and conquer. This is what we have learned throughout history from great conquerors such as Alexander the Great and Genghis Khan." (Kamberi, 2016: 7). Considering the examples and evaluations above, it is suitable to say that epics can play an important role for a better understanding of today's authoritarian regimes and the paradox of "obey or die" that many countries and opposition groups within those scenarios are forced into.

\section{Innocent or passive enemy}

Some of the characters in the epics are described as enemies because of their behavior which conflicts with social values, or some other reasons such as not making sacrifices, or in some manner not conforming to demands or expectation. The characters acting in these behaviors in the epics are marginalized. Thus, these characters, who become an "other", do not even need to be committing negative actions directly affecting the hero. They are inherently enemies.

In the epic of Manas, Kongur Bay and Ürbü are regarded as enemies because they are from other nations, and Afghanistan's king Mus Buçak is considered an enemy without any reason. These characters have no hostile attitude towards Manas in practice. Forming these characters as enemies certainly has a functional purpose in terms of text, such as making an epic more inspiring. However, it includes a connotation about what the fate of those who prefer the wrong side or those who choose to live in their own way, as it is in the slogan "bitaraf olan bertaraf olur (inferred the one who is impartial is to be defeated)" used among Turkish people.

In the epic of Kocacash (Kocacaş) of Kyrgyz, the enemy is an anthropomorphic goat named Sureçki. She does not have any hostile attitude towards the hero, Kocacash. The thing that makes her an enemy is her resistance to death and sense of revenge. The expression of the hero in the epic, "the God creates me as a nemesis to you"(Köse, 2002: 290) indicates that the enmity originates from the law of nature. This quote shows that sometimes there is actually no need for any reason for making enemies. Also, in the epic of Koroghlu, most of the hero's enemies take no negative action against the hero. Besides this, the hero of this epic resorts to trickery while fighting against the enemy, which is presented by the narrator as a sign of intelligence. Contrary to this, the trickster enemy is portrayed as evil and punished because of his tricks. This is a typical example of the fact that the ethical fundamentals of the actions within the epic change according to the person performing it, and are attributed with subjective bias. 
This structure of making an enemy in the epics shows that there is, in fact, no need for any reason in order to marginalize a character and to make him an enemy. Forms of marginalizing or demonizing of a group, belief, political movement or a country are actually one of the foreign policies seen in every period of history. Throughout history, many political leaders have demonized or villainized adversaries to create enemies for the purpose of rallying allies against them and empowering control over the adversaries. ${ }^{6}$ In doing this, enemies in the epics may be created by narrators in order to influence the audience, not unlike modern war propaganda. According to the scholar Philip Cole, the border between fictional work and narratives of the real world can be made unclear, so it is possible that people might not distinguish an imaginary fear from a real one. (Cole, 2006: 101-102).

In this context, Cole's claims support the assumption about marginalizing in order to create an enemy:

"The boundary between fiction and reality is blurred, or rather our awareness of where that boundary line is blurred, and everyday life itself is framed within the fictional constructs of our imagination or the imagination of our political and cultural leaders." (2006: 101).

To give an example of political propaganda in a major motion picture; many critiques of Invasion of the Body Snatchers (1956), directed by Don Siegel, identify the film as an allegoric work which supports anti-communist propaganda during the Cold War period (Dodd, 2014; Sanders, 2008: 55-72; Wood, 2001). Therefore, it is possible to claim that while these marginalization attempts were carried out through the epics until a certain period of the history, the media sector satisfies these needs today (Duman, 2020: 363).

\section{Conclusion}

This study, which deals with the "reasons for not questioning the negative actions of the epic hero" and "how to work the enemy making process in epics", reveals two important claims: The first of these is that there is a strong relationship between not questioning of the actions of the epic hero and not questioning of the actions of the king in real-life authoritarian regimes. Analyzing this relationship comprehensively is crucial to better understand the causes of wars and even today's politics because, in the historical process, even if the ethical perceptions have varied depending upon the lifestyles of the societies, the perception of political leaders is often the same. Being told extraordinary stories (in order to attribute godlikeness to him) about North Korea leader Kim Il Sung (1912), ${ }^{7}$ who appeared after 4,000 years of ancient Egyptian pharaohs attributed to God or semi-god might be one of the most obvious examples to show that perceptions and practices of some political leaders remains the same as in the epics even in today's modern world. Epics are one of the resources that helps us to closely understand this perception. Therefore, it is a very strong assertion can be made that although the period of composing an epic for most nations in the world has come to an end, the understanding of a hero who cannot be questioned and the policy of enemymaking still exists similarly in real life. Accordingly, re-examining the epics with different perspectives is very important for understanding these things happening in today's world. 
The second important claim of this study is that empathy with the enemy is very important in the struggle against evil. For this, it may be advantageous to consider the enemies in the fictional world as a sample. In doing so, we may find that many of our perceived enemies are not truly evil, but perceived as such because they are merely foreign to us. Accordingly, ignorance leads to acquiescence and acquiescence accompanies insensitivity. The war, the massacre, or the attacks which are the embodiment of radical evil have been experienced in all periods of history, but acquiescence and, most importantly, insensitivity to evil has made it difficult to overcome radical evil. Humanity acknowledging the occurrences of radical evil in the world with honesty among ourselves must be the catalyst for peace. Examining the enemies that are fictional reflections of evil in the real world from a different point of view will contribute to our understanding of whom and what is evil in the real world, and who is really needed to be regarded as an enemy.

\section{Endnotes}

1 see Miller 2000: 70-73

2 Turkish folklorist Ali Duymaz investigates the types of looting in Turkish culture and how they reflect on epics in his article examining the festival traditions in Turkish culture (Duymaz, 2005: 37-60).

3 In contact with a similar subject, Bowra questioned the reality of the Kyrgyz's Manas and the Kalmuks' Dzangar. Expressing that these characters are not directly related to history and real life, Bowra emphasizes that they are ideal heroes reflecting national consciousness but that does not completely mean they are not based on historical personages. Secondly, a historical personage is presented by being idealized to his people, which results in the design of a historical personage as an ideal epic hero. Vladimir of the Russians and Marko Kraljevic of the Serbs are such characters (Bowra, 1952: 534). Even if some epics take its source from historical personages and events it is possible to claim that these characters and events can be reshaped according to the event pattern in the epics and relationship between storyteller and audience (see Bowra, 1952: 534-535).

4 (see Karataş, 2017; Yereli, 2010)

5 Dolkun Kamberi makes an evaluation on this manifest, which corroborates our opinion, in his work titled Ancient Heritage of Täklimakan: Uyghur Urbiculture: "This medieval Uyghur king's declaration at his coronation amounts to only eight lines of verse, plus another line giving the king's order to send the eight lines out to all other states. But its content is so rich that it includes everything important to a state. In my opinion, this is the shortest and best speech by any khan, king, emperor, chairman, or president throughout world history. Its implied concerns include strengthening the military, developing animal husbandry and the irrigation system for agriculture, faith, the environment, politics, and the Uyghur kingdom's foreign policy.” (2016: 7).

The process and types of enemy making is defined in The Sage encyclopedia of war: Social science perspectives as follows: "Enemy making or enmification is a process through which people dehumanize their adversaries. Three types of explanations can be discerned for why people need enemies. One theory is that people psychologically need enemies as suitable targets for the displacement of their personal fears and hostilities (Volkan, 1985, 1988). The second explanation is political: leaders create enemies to mobilize the nation around common aims or to profit from the arms industry (Murray and Meyers, 1999). The third explanation is that enemy making is a natural and crucial factor in combat because it helps to construct a distance between soldiers and their enemies which is crucial in order to be able to kill adversaries (Grossman, 1995)". (Sion, 2018).

7 (see Andrei, 2013).

\section{References}

Bang, W. and Rahmeti, R. G. (1936). Oğuz Kağan destanı. İstanbul: Burhaneddin.

Bowra, C. M. (1952). Heroic poetry. London: MacMillan.

Campbell, J. and Moyers, B. (2013). Mitolojinin gücü: Kutsal kitaplardan Hollywood filmlerine mitoloji ve hikâyeler. Z. Yaman (Trans.). İstanbul: MediaCat.

Cole, P. (2006). The myth of evil. Edinburgh: Edinburgh University. 
Duymaz, A. (2014). Oğuz Kağan Destanı'ndan Dede Korkut'a toy geleneğinin simgesel anlamı ve Türk paylaşım modeli. Karadeniz Araştırmaları, 5 (5), pp. 37-60.

Duman, M. (2020). Türk halk anlatmalarında olumsuz tipler-Mit, destan, halk hikâyesi-. Ankara: Karakum.

Ergin, M. (1997). Dede Korkut Kitabı giriş-metin-faksimile. Ankara: Türk Dil Kurumu.

Hobsbawm, E. J. (2007). Kısa 20. yüzyıl: Aşırılıklar çă̆ı 1914-1991. Y. Alogan (Trans.). İstanbul: Everest.

Kaplan, M. et al. (Eds.) (1973). Köroğlu Destanı. Ankara: Ankara Üniversitesi.

Karataş, M. (2017). Göçerevlilik ve yerleşiklilik bağlamında Selçuknâme'deki kültür unsurları. TÜBAR, XLII, pp. 127-170.

Kearney, R. (2012). Yabancılar, tanrlar ve canavarlar: Ötekiliği yorumlamak. B. Özkul, (Trans.). İstanbul: Metis.

İsakov, A. et al. (2017). Manas: Soghimboŭ Ǔrozbek ŭghli varianti bǔiıicha: Manas destanı: Sagımbay Orozbak Uulu varyantı. İstanbul: Türk Dünyası Belediyeler Birliği.

Köse, N. (2002). Kocacaş Destanı Üsönbayev, Konokbayev ve Ceentayev varyantları inceleme-metin. Ankara: Milli Folklor.

Lankov, A. (2013). The real North Korea: Life and politics in the failed Stalinist utopia. Oxford: Oxford University.

Miller, D. A. (2000). The epic hero. Baltimore MD: Johns Hopkins University.

Sanders, S. M. (2008). Picturing paranoia: Interpreting Invasion of the Body Snatchers. In S. M. Sanders (Ed.), The Philosophy of Science Fiction Film (pp. 55-72). Lexington KY: University of Kentucky.

Sion, L. (2018). Enemy making. In P. I. Joseph (Ed.), The Sage encyclopedia of war: Social science perspectives. Thousand Oaks CA: SAGE.

Suleymanov, A. et al. (2014). Başkurt destanları IV: Tarihi destanlar, kahramanlar hakkında destanlar, ozanlar (sesenler). M. Ergun, G. İbrahimov, F. Aetbaeva and M. Y. Kaya, (Trans.). Ankara: Türk Dil Kurumu.

Sümer, F. et al. (Eds. \& Trans.) (1991). The Book of Dede Korkut: A Turkish epic. Austin TX: Univ. of Texas.

Yereli, A. B. (2010). Yağma kültürüyle üretim kültürü arasında Türklerin devlet ideali. Orhon Yazıtlarının Bulunuşundan 120 Yll Sonra Türklük Bilimi ve 21. Yüzyll Konulu 3. Uluslararası Türkiyat Araştırmaları Sempozyumu Bildirileri. Ankara: Hacettepe Üniversitesi, pp. 941-949.

Yıldız, N. (1995). Manas Destanı (W. Radloff) ve Kırgız kültürü ile ilgili tespit ve tahliller. Ankara: Türk Dil Kurumu.

\section{References (Online)}

Dodd, M. (2014). Safe Scares: How 9/11 caused the American horror remake trend (Part one). The Missing Slate. http://themissingslate.com/2014/08/31/safe-scares-how-911-caused-the-americanhorror-remake-trend-part-one/\#.VARTBvldUgs. (Retrieved September 2, 2018)

Kamberi, D. (2016). Ancient heritage of Täklimakan: Uyghur urbiculture. https://www.rfa.org/english/ bookshelf/uygpdf.pdf. (Retrieved September 1, 2018)

Wood, D. (2001). Invasion of the Body Snatchers (1956). BBC Home. http://www.bbc.co.uk/ films/2001/05/01/invasion_of_the_body_snatchers_1956_review.shtml. (Retrieved September 2, 2018) 
folk/ed. Derg, 2020; 26(4):839-858

DOI: $10.22559 /$ folklor.1338

\title{
The Dimension of Belief in Veganism/ Vegetarianism
}

\author{
İnanç Boyutuyla Veganlık/Vejetaryenlik
}

\section{Meryem Bulut ${ }^{*}$ \\ G. Yasemin Tunçay**}

\begin{abstract}
This study analyzed the views of vegans who define themselves as Muslims, Atheists or Deists. Questions such as 'How did you decide to be a vegan?', 'Please present your opinion about sacrificing an animal for God' etc. were asked to the participants in order to evaluate their views. In-depth audiorecorded interviews were conducted with individuals over the age 18 which were then, decoded and interpreted. The interviews took place between April 9 and November 8, 2017. Upon completing the analyses, it was determined that some Muslim vegans want to live and behave according to the specific religious identity and continue life as vegans without exploiting innocent living beings at the same time. On the other hand, some of the interviewed individuals mentioned that the notion of sacrifice in Islam has changed in time and it is no longer correct to sacrifice animals for Allah in Islam. According to the obtained data, Muslim vegans do not usually put the vegan identity forward and avoid politicization. Muslim vegans also reported that they stay away from
\end{abstract}

Geliş tarihi (Received): 30.05.2020- Kabul tarihi (Accepted): 10.09.2020

* Doç.Dr., Ankara Üniversitesi DTCF, Antropoloji. meryem.bulut@gmail.com. ORCID 0000-0001-9857-7307

** Dr.Öğr.Üyesi. Çankırı Karatekin Üniversitesi Sağlık Bilimleri Fakültesi. gyasemintuncay@gmail.com. ORCID 0000-0003-4872-1096 
activist vegan groups. The common aspect among Muslim, Atheist and Deist groups is that they are against capitalism.

Keywords: belief, ethics, religion, sacrifice, vegan, vegetarian

\section{$\ddot{\mathbf{O} z}$}

Bu araştırmada veganlığı benimsemiş ve kendilerini Müslüman, ateist ve deist kimliği ile tanımlayan bireylerin görüşleri ele alınmıştır. Görüşülen bireylere "vegan olmaya nasıl karar verdiniz?", "kurban (hayvan kesme) olayını değerlendirir misiniz ?” vs. sorular yöneltilmiştir. Müslüman veganların; veganlık ile kurban konularını birlikte nasıl değerlendirdikleri ele alınmıştır. Çalışma için 18 yaş üstü kadın ve erkekler ile derinlemesine görüşmeler yapılmış ve yapılan görüşmeler izin alınarak ses kaydına alınmıştır. Kayıtlar deşifre edilerek yorumlanmıştır. Görüşmeler 9 Nisan-8 Kasım 2017 tarihleri arasında yapılmıştır. Araştırma sonucunda Müslüman veganların hem Müslüman kimliklerini yaşamak istedikleri, hem de masum canlıları sömürmeden vegan olarak yaşamlarını sürdürmek istedikleri, bazılarına göre de İslamiyet'te kurban konusunun zaman içinde değiştiği ve kurban için hayvan kesilmesinin İslam dini ile ilişskilendirilmesini yanlış buldukları belirlenmiştir. Müslüman veganların; çevreleriyle ilişkilerinde vegan kimliklerini öne çıkarmadıkları, politize olmaktan kaçındıkları belirlenmiştir. Müslüman veganların aktivist vegan gruplardan uzak durdukları saptanmıştır. Hem kendilerini Müslüman kimliği ile ifade eden veganların, hem de ateist ve deist kimliği ile ifade eden veganların ortak noktalarının kapitalizm karşıtlığı olduğu sonucu ortaya çıkmıştır.

Anahtar sözcükler: inanç, etik, din, kurban, vegan, vejetaryen

\section{Introduction}

Similar with the popularization of the issue all over the world, it is seen that researches about Veganism/Vegetarianism have been increasingly known and the number of these studies about the issue has been increasing every day in Turkey (Sünnetçioğlu et.al., 2017; Erben and Balaban-Sal1, 2016; Cömert and Durlu Özkaya, 2014; Clarys et.al., 2014; Dyett et.al., 2014; Leitzmann, 2014). It is accepted that Veganism/Vegetarianism isn't simply a type of diet; it is a lifestyle, a philosophy and a bioethical approach (Pollan, 2009: 361395; Singer, 2005: 224-255; Tunçay and Bulut, 2019; Tunçay, 2020). 35\% of India, 9\% of Italy and Germany, approximately $4 \%$ of America is vegetarian and $2 \%$ is vegan (Le and Sabaté, 2014; Leitzmann, 2014). There are different reasons why people prefer to be vegan or vegetarian. Some of them prefer this lifestyle in order to have a healthy life, while some others prefer this diet because of ethical reasons. There are some people who prefer this diet because of their belief while some individuals have more than one reason for this lifestyle (Best, 2009: 371; Karabudak, 2008: 8-9; Kıran, 2015; Pollan, 2009: 361-395; VEBU, 2015; Vegetarian Society, 2020). 
The Latin root of the word vegetarian is 'vegetus', and it means full of life, healthy and lively (Vegetarian Club, 2015). Vegetarians don't eat any kind of animal meat (red meat, chicken, fish, etc.), they eat limited secondary animal products while sometimes they never eat them (yogurt, egg, milk, etc.) (Karabudak, 2008: 7; Vegetarian Society, 2020; Vegan Association of Turkey, 2020). Veganism, on the other hand, means not consuming any kind of animal products including secondary products such as milk, yogurt, cheese, and honey. In addition to these, vegans don't wear clothes made of animal products such as wool, silk, leather and they don't use products tested on animals such as cosmetic products, detergents, toothpaste etc. (Pilis et. al., 2014; Vegan Association of Turkey, 2020; Phillips, 2005; Karabudak, 2008: 7-8; Vegetarian Society, 2020; Çetin, 2014; Kınıkoğlu, 2015: 17, Türkmen, 2015; Yıldırım, 2015). Veganism is a bioethical approach based on the beliefs about protecting animal rights, respecting the life of living creatures, equality of species and living beings (Tunçay, 2020). Veganism is a lifestyle (Tunçay Son and Bulut, 2016) and most of these members of these societies act according to their beliefs in their daily life. The goal of this study is to determine the views of Muslim Vegans about the sacrificial ritual carried out by individuals who believe in Islam. The focus of the study is the questions of how do Muslim individuals define veganism, how do they associate veganism with their religious belief. So, the basic point of the research is the views of individuals who embrace a vegan lifestyle.

\section{Method}

\subsection{Type of the research}

The research is based on the views of vegans/vegetarians who define themselves as Muslims, Atheists or Deists about the issue of being vegan/vegetarian, sacrificing an animal and self-expression.

Our study, based on qualitative research was carried out with a total of 16 individuals to whom we could reach and took consent; the process based on in-depth interviews continued from April 9 to November 8, 2017. In-depth interview is one of the basic data collection methods of anthropology. This technique, used in other disciplines of social sciences gives the researcher the opportunity to analyze an issue thoroughly, in details (Kümbetoğlu, 2005:71-72).

\subsection{Collection of data}

Interviews are carried out with male and female individuals over the age of 18 . We reached vegan individuals through snowball method by analyzing social media besides published and online magazines (Gaia, Sustainable Life) about the vegan lifestyle. Through this snowball technique, it was possible to reach from one individual to another, from individuals to states (Baltac1, 2018: 246). Informed consent was obtained from all individual participants included and no funding was received in the study. Before the interview, participators were informed about recording their voice during interviews and the process was recorded upon their approval. During interviews, demographic data of the individuals were learned and 
various questions about the issue were asked (ex. How did you decide to become vegan? How do you define your identity? Please evaluate the sacrificial ritual.) At the end of the interviews, conductors asked the individuals if they want to have something else to say about the issue or if they want to add something about veganism.

\subsection{Evaluation of data}

Different individuals who define themselves as vegans or vegetarians are included in this research; their stories are listened through in-depth interviews, recorded and decoded in order to interpret and use the data for the qualitative study.

\section{The root of sacrifice ritual}

Sacrifice is a ritual related to religious, historical, sociological, psychological and cultural factors (Örnek, 1989:121). The individual acknowledges social powers by forgoing personal rights and increasing mental energy by sacrificing something/someone, but the most important function of this ritual is that it reminds the existence of collective powers represented by Gods. Based on this meaning it can be said that the word has a connotation: a sacrificed living being. (Roux, 2005:187). It is stated that the word is derived from the Latin words "sacrificare" or "sacrificium". Sacrificare is a verb meaning offering objects to a God or to other supernatural existences, to make objects the possession of a God and to sanctify them (Güç, 2002:1). On the other hand, as an offering is presented after a victory, according to Roux the ritual involves a meaning of winning (2005: 187).

The Turkish word kurban ${ }^{1}$ (Qurban-offering-sacrifice) is based on an Arabic root "krb", which means "becoming closer-being close". The two other Turkish words based on the same root "akraba" and "takriben" connote the meanings of the words "close" and "approximately". The word offering (Kurban) in Turkish has a religious (sacred) meaning in it. According to this meaning, sacrifice should always exist within a sacred environment. Eliade defines offering as the reconstruction of cosmic time and cosmogony through repetition. Construction of an altar, according to him, is perceived as "creation of the world" (1994: 82-83). An offering is also defined as a present independently presented to a belief system to minimize enmity by ensuring the grace of the supernatural (Erginer, 1997: 21).

Offering $^{2}$; it is the animal slaughtered to fulfill the order of religion or vow. The meat of animals, which are slaughtered to gain the grace of God, is given to the poor. Sheep, goat, cattle, and camel are some of the animals used in this ceremony.

The first societies that adopted sedentary life used to pour drinks, present a variety of plants, dust flour, sacrifice animals and sometimes human beings for Gods (Childe, 2005:21). Although the exact beginning of sacrificing animals is not known, it is commonly believed that it goes back to old ages. According to Childe, the ritual of sacrificing goes back to Homo Neanderthalensis which was the first community with graves and tradition of burying the dead (2005:21). 
Mesopotamia, Anatolia, Egypt, India, China, Persia, and Hebrew mythologies indicate that there were ceremonies of presenting offerings in some specific months of a year. The most famous example of offering in the history of humanity is the attempt of Abraham, accepted as a Prophet by Jews, Christians, and Muslims. According to this common belief, Abraham attempts to sacrifice his son for God.

As sacrificing involves the act of killing, destroying a natural order, it is highly meaningful and sanctifies life. According to Agamben, the purpose of the ritual is to gain a type of sanctity, this is why the act of destroying a life isn't simply a 'murder' (Tuğrul, 2010:109). This act of sacrificing a living being is common in the Epics of Babel Creation (Enuma Eliş) and Gilgamesh in Mesopotamia, Greek and Rome mythologies; birth, resurrection and rising from the ashes are some of the meanings attributed to this act. These attributions indicate that there is a similar belief among these different communities: it is necessary to make a sacrifice for internalizing sanctity, an offering is an instrument used for this purpose (Tuğrul, 2010:20-24).

\section{Presentation of sacrifice for different purposes}

Although there are differences in the purpose, form, and manner of rituals carried out for giving sacrifices to one or multiple Gods, they are common in almost all belief systems. Human beings, animals, fish are presented to God/Gods. Goose was the most important offering in the cult of Isis (Egypt) while horse was the most important offering for ancient Turks. Dogs, donkeys, snakes are some of the other animals offered to God/Gods (Bekki, 1996:16-28). Communities in the Middle East after the Hun Empire used to give sacrifices to earth-water, sun and moon besides Gods (İnan, 1995:9).

The offering is an element of redemption in archaic myths and a society can reach peace through the rituals of sacrificing (Tuğrul, 2010:194). Humans have always searched for compensating for their mistakes. Redemption is the word used for compensating a mistake, which involves the meanings of "removing, repairing" (Öztürk, 2002:167-193). The instrument of redemption is sometimes offering, sometimes fasting or giving alms. Such rituals are magical rather than soothing. People have believed that the course of nature is followed and internalized through rituals based on actions that involve physical proximity or similarity to nature (Frazer, 2004: 142). For instance, Cherokee Indians used to hug each other, fast or wash their bodies to reach redemption in their rituals. They used to believe that their souls are completely purified when they wash their bodies and leave their clothes to the flow of water (Frazer, 1992:156). Christians believe that they are purified through baptism; Muslims believe that they are purified through ablution, and Jews believe that they are purified through Mikveh (Cilac1, 990:199). Atonement (to right the wrong) can be reached through the water as well as making a sacrifice to God/Gods.

The sacrifice used for atonement can be an animal such as sheep, goat, dog or pig, or it can be food or drink such as wine, rice, bread or egg. It is determined that some communities used to sacrifice human beings besides animals. According to Frazer, some of the Semite kings in Western Asia would sacrifice their son in the case of a national danger. Phoenicians 
used to sacrifice their most beloved child for God Baal in the days of great disasters such as drought or war (2004:229-230).

There are various reasons for sacrificing different things for God/Gods. In modern Greece, roosters, rams, sheep are slaughtered while building a structure and blood of these animals are poured to the foundation stone; sometimes the body of the offering is buried under the stone. In some cases, a man's body is secretly measured, the object used for measurement is buried under the foundation stone or the stone is placed on the shadow of that man instead of sacrificing an animal (Frazer, 2004: 142). It is possible to see similar examples of sacrifices in Anatolia.

The act of sacrifice can be bloody (animate) or non-bloody (inanimate). Animate sacrifices are human beings, animals, fish or food products besides living beings. On the other hand, animals that are released (1d1k/1duk) are also named non-bloody sacrifices; it is determined that such sacrifices were common among Yakut Turks. They believe that The White Creator (Ayı Tangara) is the God that gave life (kut) to humans and created the universe; they give animate offerings to this God. The act of sacrificing means setting the animals free. This is called $1 \mathrm{~d} 1 \mathrm{k} / \mathrm{lduk}$ (released/sent). Animals that are set free aren't eaten, their milk cannot be consumed, and they cannot be used for carrying any kind of load. Yakut people release their horses towards Eastern areas for sacrificing them for the Creator (Ögel, 2010:431). Gagauzian rich farmers pick one of the best young bulls as an offering and set is free in the nature for "Allah" (Güngör, 1991:36).

Sacrificial meals gather people together and create both religious and social bonds through ceremonies (Fieldhouse, 1996:121). The root of these fests goes back to some ancient traditions. During eating, which is perceived as a social behavior, older practices are remembered and repeated. People who eat and drink together connect to one another through the bonds of friendship and responsibility. All of the ordinary functions of prayers in older religions are carried out during sacrificial meal. It represents the natural relationship between Gods and humans, but the act of eating and drinking together has a sacred meaning. The act improves the ties among members of societies, just like the ties between humans and Gods (Smith, 2002: 247-8). Sacrificing different things or living beings to Gods is one of the ways used for preventing unwanted events and for reaching desires.

\section{Sacrifice in monotheist religions}

The first example of sacrifice is in the book of Psalms, written in Hebrew. Although Psalmbook and Torah have some common features, detailed descriptions of rules aren't included in Psalmbook. It is important to note that the source of sacrifice in the Torah is in Psalmbook ${ }^{3}$.

The first traces of sacrifice in Monotheist religions go back to Cain and Abel. "Recite to them the truth (730) of the story of the two sons (731) of Adam. Behold! They each presented a sacrifice (to Allah. It was accepted from one, but not from the other. Said the latter: "Be sure I will slay thee", "Surely," said the former, "(Allah) doth accept of the sacrifice of those who are righteous." God accepts the sacrifice of Abel, and Cain kills him (Öztürk, 2016: 515). Qur'an scholars claim that the reason why Cain killed Abel is that while Abel's sacrifice was accepted by God, Cain's sacrifice wasn't accepted as mentioned in Maide Sura (Yetik, 2012). 
The names of brothers Cain and Abel in the Torah ${ }^{4}$ aren't mentioned in Qur'an. As the story in Torah is in the section of creation, the issue isn't related to sacrifice. [They are] those who said, "Indeed, Allah has taken our promise not to believe any messenger until he brings us an offering which fire [from heaven] will consume." Say, "There have already come to you messengers before me with clear proofs and [even] that of which you speak. So why did you kill them, if you should be truthful?"5 The statement "an offering which fire will consume" in this verse of the Qur'an indicates a historical story believed bf Jews. According to the belief, the sacrifice is turned into ember by God with fire.

Prophet Abraham, directly associated with sacrifice in monotheist religions is related to a community with a religious tradition. Abraham's act of sacrificing his son is the practice of sacrificing the first child, which was quite common in Ancient-Eastern world and continued until the age of Prophets in Hebrews. Abraham's act of sacrifice starts a new belief system (Eliade, 1994:109-110). There are various different examples of human sacrifices in history (Frazer, 2004:383-390). The act of sacrificing a first child means giving God back what he actually owns in the first place. In this respect, as Sara gave birth to a child after her age of fertility, Isaac is basically the son of God.

Qur'an ${ }^{6}$ indicates that sacrifice is revealed to Abraham by God. Construction of Kaaba by Abraham, creation of rituals about sacrifices and the attempt to sacrifice his son are included in the narratives in Qur'an?

There are some differences in the interpretations of religious scripts about the sacrifice, we don't know if it was Ishmael and Isaac. According to the Torah scripts, the son that was attempted to be sacrificed was definitely Isaac ${ }^{8}$ while there are more ambiguous expressions in Qur'an scripts. When the verses of Qur'an are evaluated in general, it can be said that Ishmael was the son that was to be sacrificed ${ }^{9}$. The God sent a ram to prevent sacrificing a human being.

The most important instrument of redemption in the Old Testament is offering religious ceremonies that save humans from their sins. According to the Torah, a young bull should be sacrificed for a sin offering every day ${ }^{10}$. On the other hand, human being should purify themselves; fasting, charity, flour, praying and death are the other instruments of redemption mentioned in the Old Testament. The belief that offering is the most important instrument of redemption is based on the understanding that life depends on blood. The basic penance according to this belief is blood ${ }^{11}$.

There are rules to be followed while sacrificing an animal for God as an offering. The place where the animal will be slaughtered, the place for its blood, the place for burning internal organs, rules to be followed by the owner of the offering are mentioned in details in the Old Testament ${ }^{12}$.

Christians believe that Prophet Jesus sacrificed himself because of the Original Sin. This understanding of crime that associates sin to a community rather than a single person goes back to old times. In Christianity, lifting the rule of sacrificing animal is based on the last supper. "While they were eating, Jesus took bread, and when he had given thanks, he broke 
it and gave it to his disciples, saying, "Take and eat; this is my body. Then he took a cup, and when he had given thanks, he gave it to them, saying, "Drink from it, all of you. This is my blood of the covenant, which is poured out for many for the forgiveness of sins." 13

Another Christian ceremony for redemption is Eucharistia, which is the "Holy Table", "The Ritual of Bread and Wine", "The Communion". "Every high priest is selected among the people and is appointed to represent the people in matters related to God, to offer gifts and sacrifices for sins" in the New Testament ${ }^{14}$; but Prophet Jesus presented himself to the God with tears and prayers and ensured the salvation of all believers. The presentation of the body of Jesus ended the era of offerings and gifts in Christianity; Eucharistia, the offering without blood remains in the belief system. Christians practice the Ritual of Bread and Wine to memorialize the crucifixion of Jesus Christ (Schimmel, 1999:170).

The word of sacrifice in Islam means connection, closeness to God; Prophet Mohammad's statement, "salat (prayer) is sacrifice" confirms the meaning, importance of sacrifice in Islam (Oymak, 2002:169-180). Products based on cereal, any kind of drinks or animals can be presented to God as sacrifices. Sacrifice is mentioned in Ali İmran /183, Maide /27 and Hac 134 verses of the Qur'an. In the Surah named Hac, it is mentioned that "To every people did we appoint rites (of sacrifice), that they might celebrate the name of Allah over the sustenance He gave them from animals (fit for food)..." According to these words, sacrifice is a condition in the religion of Islam; each Muslim should fulfill this order.

\section{Historical process of veganism and vegetarianism}

It is thought that vegetarianism firstly appeared in old European and American cultures. The first written texts about vegetarianism in Europe belong to Ancient Greek Orpheists who didn't eat meat. In 5th century BC, vegetarian Empodices stated that not killing other living creatures is a virtue. There are rules about being nice to animals in many religions. Starting from very old ages, approximately 3000 years ago, Hinduism, Jainism, and Buddhism have embraced the understanding of vegetarianism because of health and ethical values that they still have (Best, 2009; Kınıkoğlu, 2015: 15; Leitzmann, 2014). On the other hand, it is believed that there is a relation between vegetarianism and Greek philosopher and mathematician Pythagoras's ideas about reincarnation. Pythagoras is accepted as the father of ethical vegetarianism (being vegetarian because of ethical reasons). It is known that many scientists such as Leonardo da Vinci in the Renaissance period and Tryon, Rousseau, Voltaire in the Enlightenment period were vegetarians (Leitzmann, 2014; Türkmen, 2015; Kınıkoğlu, 2015: 15).

The first vegetarian union was established in 1847 in England. After that, many vegetarian unions were established in various countries. International Vegetarian Union was established in 1908, in Dresden. The word Vegan was firstly used by Donald Watson in 1944 and The Vegan Society was established in England in the same year (Leitzmann, 2014; Kınıkoğlu, 2015: 15; Türkmen, 2015). Vegan \& Vegetarian Association of Turkey (the name is Vegan Association since April 2018) was established in 2012 in Turkey; the union is a member of International Vegetarian Union and European Vegetarian Union (Yıldırım, 2015). 


\section{Religions and their relations with veganism/Vegetarianism}

Religion symbolizes the attitude of human beings towards an incomprehensible order in the world that surrounds them. Religion is shaped in the search for supernatural. The elements that are in the origin of religions and define, shape and give original features to them may have 'historical' resources (Bottore and Kramer, 2017: 55-56). Durkheim defines religion as 'a combinational system of belief about holidoms and practices'. There are various definitions of religion. According to Cicero, the word 'religio', created by Ancient Romans, means 'being careful about what is believed to be important and carrying out duties for the Gods. The word 'Eusebia' in Greek has the same meaning (fear of God, being religious). The word 'Dharma' (Sanskrit) or 'Dhamma' (Pali) in the Hindi Language means the law, namely the rule that people should obey. 'Ciao' in Chinese, 'Kyo' in Japanese and 'Hak' in the Korean language means 'knowledge' (Gitt, 2012: 29). Religion is a combination of beliefs and worships generally including supernatural, sacred and ethical elements including various rituals, practices, values or institutions. The word 'Din' in Turkish is originated from Arabic and means 'the path, command, reward' (Aydın, 2016: 17-18, 20). In Arabic and New Persian languages the word 'Din' (religion) focuses on the rightful, lawful dimension.

Animals are used differently in different religious practices. For instance healing ritual in California, Merced is one of the practices in which animals are used; during the funeral, Hmong Shamanist, Va Meng Lee conducts a healing ritual for a sick man. Spirit of a pig is offered in order to be able to prevent the sick man from going to the other world with the dead body. Dignity Health Hospital in Merced accepts the healing power of belief and shamanists are allowed to help people in the hospital (Vance, 2016: 42).

Viewpoints of Jews and Christians about animals are based on the symbolisms such as 'The values presented to human beings by the God', 'Offering and Nutrient', 'Punishment or reward for people or for other animals', 'Military power', 'Hunting material', 'Indication of the God's power of creation', 'Helper of Mankind' etc. According to these two religions, people were allowed to feed on plants first, and then they were allowed to consume meat and animal products. When mankind was expelled from the paradise, he started to kill animals; but there are statements in the holy books of these religions about the fact that animals are created for the benefit of mankind, but they are precious and they have rights (although they have a few rights) (Armutak 2008). Bible says that God created mankind in the image of God and we (including animals) use natural sources for our benefit. Christian thinkers state that animals lack the ability of reasoning and they are below mankind. Although the same understanding is accepted in Judaism, the religion has a long tradition and states that it is important to ease the pain of animals, decrease their pain as much as possible. According to this religion, all of the creatures of God deserve mercy (Degrazia 2002).

The value attributed to animals is especially obvious in Ahimsa Jainism. According to this belief, mankind should prevent giving any kind of damage to living creatures (Aydin 2016, 104-105). In most of the religions -whether the religion has a holy book or not- the rule 'treat people you want to be treated' is accepted. Confucius stated that 'one should treat people he wants to be treated'. About animals, Islam states that 'one cannot be a real Muslim 
if he doesn't wish what he wants for himself for his brother'. Buddhism mentions that animals should be treated the way that we treat each other and states that: 'A situation that is not comfortable or enjoyable for me cannot be comfortable or enjoyable for another, so how can I force another living being for such a situation?' Hinduism point of view about animals is included in the statement that 'one should treat people he wants to be treated'. On the other hand, Jainism states that 'Mankind shouldn't tend to deal with earthly affairs, and one should treat people he wants to be treated' (Iş1k 2011, 143-154). None of the beliefs in the world approve the cruel treatment of animals.

\section{Islamism and veganism/Vegetarianism}

The religion of Islam doesn't accept any kind of cruel treatment of animals. Any kind of suckling animal shouldn't be separated from her mother and slaughtered. On the other hand, Prophet Muhammad stated that while taking the milk of an animal for using, some milk should be left for a baby animal. According to Islam, it is not acceptable to provoke animals and make them fight with each other (Sinmez, Arıcan and Yaşar 2015).

It is seen that in today's milk industry, animals are treated badly, they are kept under terrible conditions and rules of religions aren't taken into consideration. A milk production cycle of a cow starts when her first calf is taken away from her. The cow is milked twice or three times in a day for ten months; at the end of the third month, she has impregnated again and the process of milking her continues until there are six or eight weeks before giving birth. After she gives birth, her calf is taken away from her again. This intensive pregnancy and milking cycle can continue a maximum of 5 years. The 'consumed' cows are then sent to slaughterhouses if they can survive the process. Other farm animals are treated the same (pig, chicken, etc.) (Singer 2005, 147-223; Francione 2008, 62-76; Degrazia 2002, 105-109).

\section{Islam and sacrificial ritual}

In Sumerian tablets, it is mentioned that Ziusudra builds a ship and saves his family and some animals from the flood, thus he saves his ancestry. After the flood, 'He prostrates in front of Utu, the King kills an ox and slaughters a sheep' (Hooke, 1993: 32), In Akad, Utnapiştim states that 'I sacrificed and animal' after the flood (Bottero and Kramer 2017, 655). The concept of offering animals to God is included in various mythologies. Similar to Sumerian and Acadians, there have been various sacrificial rituals in different places on earth. According to Emiroğlu and Aydın, sacrificing an animal is a symbolic gift for the supernatural. There is a relation between the offerings and the supernatural; religious and social functions and meaning are attributed to the offering. The concept of offering is separated into two as 'blooded' and 'non-blooded'. The practice of not drawing the blood of the offering on the floor is classified as 'non-blooded' (Emiroğlu and Aydın 2003, 507508). Sacrificing an animal in the religion of Islam is based on the Sura (a section of Qur'an) of Kevser in Qur'an; in the Sura, it is said that: 'Therefore to thy Lord turn in Prayer and Sacrifice.' Similar statements are also mentioned in Maide and En'am Suras (Öztürk 2013). 
Muslims base the ritual of sacrificing an animal on the Prophet Abraham. In his dream, Abraham sees that he sacrifices his son for God and explains this dream to his son; his son says that he can be sacrificed for Allah. Father and son are tested with this dream. 'We called out to him "O Abraham!" Thou hast already fulfilled the vision!" - Thus indeed do. We reward those who do right. For this was obviously a trial. And we ransomed him with a momentous sacrifice" (Saffat, 37/103-107). Eliaçık, who defines himself as an anti-capitalist Muslim and created an Islamic-Politic view, interprets this statement in Qur'an as implying preventing sacrificial ritual. According to him, in Abraham's dream, Allah wants to warn people and says: "I don't want a sacrificial ritual." So, Abraham is prevented from a mistake. While he thinks that it is Allah's order, he has some feelings on the last minute and prevented from sacrificing. In the related verse of the Qur'an, it is said that we saved him from a big mistake; but the translation is made as "we gave him a big sacrifice". So it is meant that while preventing sacrificing a son, a ram is given as an offering; but this meaning isn't included in the Qur'an; the word 'zebih' used in the related verse it means both making a mistake and sacrificing an animal at the same time. So, the interpretation in here is not true; the myth of Abraham in here is false according to Eliaçık (Özbirinci 2015).

Some Muslims, on the other hand, state that the service of sacrifice is fardth (obligation). People who defend this viewpoint mention that the importance of this obligation is mentioned in Qur'an. $36^{\text {th }}$ verse of the sura named Hac is the basis of these claims. The offering is interpreted as: "The sacrificial camels we have made for you as among the symbols from Allah: in them is (much) good for you." 15 The service of offering is obligatory according to most of the Hanafi community.

There are some communities defending that difference of opinions are based on the contradictions in terms. People who defend that sacrifice is fardth claim that there are various verses in Qur'an that support this claim. Besides this interpretation, there are some Muslim communities who claim that the duty is sunnah rather than fardth; according to this interpretation, as Mohammad closely followed this rule, this sunnah is significant, thus should be carried out (Düzbayır, 2013: 96-97). According to Şahin, the service of sacrifice is a ritual that should be properly and regularly completed and the members of the community that carries out this ritual become closer (2010: 227). The ritual of sacrifice enables people to create and support the sense of being together.

Discussions about the ritual still continue today among Muslims. Turkish Directorate of Religious Affairs makes statements about the issue of Qurban (Sacrifice); Qurban is to be offered by those Muslims of sound mind, mature (have reached puberty), have a specific amount of goods/money other than basic necessities and debts, who is not safari (on a travel) and in possession of 80.18 grams of gold or the equivalent in wealth." (Turkish Directorate of Religious Affairs, 2018:17). 


\section{Findings and discussion}

The interviewees were between the ages 16 and 60; ten of them were female while 6 of them were male. More than half of these individuals were graduated from university while half of them were married. All of the interviewees except one used to live in different regions of Turkey, in cities. More than half of these vegan interviewees defined themselves as Muslims while half of these Muslim individuals mentioned that they live according to Islamic rules on a daily basis. The other half of the interviewees defined themselves as Atheists or Deists.

\subsection{The decision of becoming vegan}

It is determined that some of these vegan individuals were affected by social media, while some of them were affected by friends. Besides that, it is seen that an individual used to witness the suffering of animals at the early ages as his father was a butcher, and this individual chose to continue his life as a vegan. Some of the interviewees stated that they were against the exploitation of animals. One of the interviewees said: "How can I resist being exploited while there is a being on your plate that used to have a spirit and feelings?" Some of the interviewees mentioned that they chose to live this lifestyle when they got to know the animals better. Another one said that "Suffering of an animal is similar to the suffering of a human being. And if she suffers, then she has the right to live." An interviewee stated that justice was the reason why he chose this lifestyle: "I don't think that this is fair. None of the living beings on earth -plants, animals, human beings- has been exploited like animals."

It is stated that a vegan individual continuing an orthodox Islamic lifestyle had significant difficulties while choosing and continuing this lifestyle. "I have become a vegan in a very difficult environment in this respect, my family and people and around me have a very strong religious system."

According to vegans, animal farms are the centers of exploitation. So, they see veganism as a stance against capitalism. The common point of all vegans is that they are against capitalism. A vegan said these about exploitation: "Being vegan is being against speciesism, exploitation; so it is not about one animal, it is about any kind of exploit..."

There are also some other vegans that relate this lifestyle with ethics. "I am an ethic vegan. As I don't place myself above animals ethically or morally, I don't want to be a part of this unfair process of killing and eating."

Most of the choices of veganism are about ethical reasons. Belief in justice and not being able to bear the pain of seeing animals suffer are the other reasons.

\subsection{Defining oneself as vegan}

Some of the Muslim vegans mentioned that they cannot talk about veganism with their close friends, they cannot express themselves. Some of the vegans in the study stated that although they have difficulty, they express their views about veganism and sometimes they react to individuals who consume meat. "I can speak, I am fearless. I can make insinuation 
when I see somebody eating meat in a restaurant. I don't respect these people. When I say something to them, they say that you should respect us as we respect you. But I am doing what is right, they don't deserve my respect. I am not a murderer, I am not a rapist; I just defend the right to live."

Some of the vegans define themselves as anarchists and defend that the vegan lifestyle is the correct way of living. So, as other people are on the wrong path according to vegans, they don't respect the others while they believe that others must respect them.

It is determined that some of the female Muslim vegans don't have opponent views about individuals who eat meat. It is seen that some vegan females prepare meals with meat for their families; they respect family members and use animal products such as woolen carpets.

It is seen that the husbands of vegan women who define themselves as atheists or deists don't consume animal products at home; they consume these kinds of products outside. One of the atheist vegan women had a big child who is also a vegan. While it is seen that Muslim vegan married women with children used to use meat in meals for their children or other family members, while atheist or deist vegan women don't use meat even when they prepare the meal for their family members. It is determined that a Muslim vegan male's wife and children aren't vegan. Only one male among Muslim vegans stated that he is very reactive to his non-vegan family members and people around him who consume meat.

The main difference between vegan Muslims and vegan atheists or deists is based on organization and self-expression factors. Atheist or deist vegan individuals generally want to be visible with their vegan identity and they want to communicate with other vegans, Muslim vegans try to avoid communicating with other vegans. Muslim vegans generally share the idea that they should be respected for their choices and rights, veganism shouldn't be used as an instrument for propaganda and they try to avoid turning this identity into political power. For instance, the general idea of these individuals is: "I respect people who eat meat and they respect me". Individuals who oppose turning veganism into a political power live Islamic life on a daily basis. Most of the Muslim vegans oppose activist vegans and believe that there are negative views about veganism in society because of these activists. According to activist vegans, vegan individuals should be active members of at least one group that has a strong attitude (for example feminism, environmentalism). According to them, veganism is a political standing. It is seen that atheist vegans are in cooperation with other vegans, they improve this cooperation and most of them are members of activist groups. It is determined that Muslim vegans stay away from activist groups. But it is also seen that these Muslim vegans don't feel that they belong to groups that determine daily routines according to Islamic rules. According to Tillion (2016), identity and belonging have infiltrated the smallest pores of daily life (Cited in Bulut, 2011: 65-70).

During the interviews, Muslim vegans were found to be members of neither vegan nor Muslim groups. It was understood from their statements that they don't feel like they belong to any of these groups. "I don't want to ignore my belief (Islam), because I believe in Islam and I want to continue this. But on the other hand, I don't want to exploit innocent animals... 
The best prayer is to keep the innocent alive. Actually, I feel detached, because atheist vegans cast me out while Muslims don't approve veganism and do the same". On the basis of this statement, it can be said that Muslim vegans are marginalized as they cannot be members of atheist/deist vegan groups or Muslim groups. Another Muslim vegan going through the same problems stated that: "When I say Allah, Why should I turn away from non-believers. In my environment, many Atheists do what most of the Muslims don't..." The common important point mentioned by these individuals is 'Do no harm!' "What I respect is not doing any harm. For instance, I don't care if you walk naked on the street. But I care if you give harm or damage to somebody on the street, because it is about the same issue, 'Do no harm!'

It is determined that women who define themselves as vegan and anarchists don't think and accept that non-vegan feminists are real feminists. According to them, individuals who demand justice for female human beings should demand justice for other female creatures. But Muslim vegans don't have such a belief. Based on the interviews, it can be said that Muslim female vegans don't want to be defined as feminists, and they stay away from the feminist viewpoint.

\subsection{How to be vegan?}

According to the interviewees who defined themselves as vegans, veganism means standing against sexism, speciesism, it defends animal rights, women's rights, justice, and ethics. Veganism has an equitable view and each kind of species is accepted equally. According to interviewees, veganism is the most qualified attitude towards life. People who have this lifestyle should have the belief of universal justice, so they should stand against any kind of injustice in the world.

Vegans in this study don't think that it is ethical to believe that human beings are above animals. According to them, vegan individuals should forget their egos and see themselves as a part of nature and they should be free from any kind of prejudices. According to some of the interviewees, veganism is born out of 'spiritualism'. So, it is a connection with the spirit. It is significant and necessary to be 'fair' and animals shouldn't be seen as mere 'robots'. Veganism is a way of reaching the essence of truth. Vegans, who believe that connection with the spirit is the key to reaching peace, think that if you reach that point, you will not give harm to animals or nature. According to them, each living being has a spirit; some have the body of a human while some have the body of an animal. So humans and animals are equally valuable.

Some of the interviewees stated that each feminist should also be a vegan because there is an injustice for women and animals in the world. This is why they believe that non-vegan feminists aren't true feminists. Some vegan women stand against feminists and state that "I am not a feminist, being a feminist is doing what men do, believing that females are superior to male individuals, I prefer equality." It can be said that this situation is about the belief of individuals about the meaning of feminism; these individuals believe that feminism defends superiority. 
Some of the interviewees defined veganism as defending the rights of all of the living beings; it is not limited to the rights of animals or humans. "I believe that some vegans are on the wrong path. They only defend animals. They exploit human beings. One should fight for any kind of inequality. One should help any kind of living being. I am trying to do my best for them. So I don't ignore human rights and defend only animal rights."

On the other hand, a person who has been a vegan for more than one year defines veganism as a process and states that: "Unfortunately I still have a woolen rug and I haven't reached that point yet. And when I become a friend with a vegan like you, I am sure you would go crazy when you see that rug on my floor. I am not ready for that point yet. I believe that this is a journey, a process and I haven't completed it yet. Everybody has a different family structure, right? I am living together with a non-vegan individual at home. He has a family; they have given effort for some values in life. This process cannot be completed fast. There is a carpet in my husband's room. I cannot easily convince him to throw it away. But vegans believe that such a difficult process should be completed in one day, it can be done very fast."

It is determined that while there are individuals who completely obey the rules of Islam, there are some others who don't. Individuals who define themselves as Muslims but do not obey the rules completely believe that Islam is a belief based on spiritual necessities rather than physical ones. An individual stated these about the religious belief: "I don't believe the image of Allah who is very strong, almighty is correct; he doesn't create whatever he wants and destroys whatever he wishes. For instance, when I see an animal I see engineering, design, and architecture. According to me, this doesn't imply a God that is almighty, strong and Sultan-like being, an illusionist as described in Islam or Christianity. Namely, there is a superior intelligence, a scientific view. I don't understand the language they speak, I don't believe in it. There are some paradoxes, some contradictions in my mind. I am making researches, I don't completely deny, but I don't surrender without making any researches." These kinds of statements of the interviewees show that they cannot reach absolute conclusions in terms of belief.

Muslim vegans oppose to sacrificing animals because of different reasons. But generally, they don't want to disobey and abandon Islam because they don't want to sacrifice animals. It is seen that they want to continue their worships based on the identity formed by Islam, but they also want a life without exploiting innocent creatures. Sacrificing animal has a significant place among Muslims. But some of the interviewees believe that Islamic rules are changed by some people; they believe that the issue of Sacrifice in Islam has gone under some changes in time. While some Muslim vegans believe that sacrificing an animal has no place in religion while some others think that the ritual should be carried out under some specific circumstances. According to some interviewees, sacrificing an animal isn't acceptable even though it is based on some religious rules. On the other hand, they stand against sacrificing by stating that there are some verses in Qur'an such as: "They (animals) are my silent subjects". Although there is no such verse in Qur'an, there are some hadiths (Words of Mohammad) which involve the same meaning. Some resources defend that some 
hadiths imply the protection of animals. Based on these hadiths, it can be said that animals shouldn't be killed for any reason, and torturing them is a sin (Sinmez, Arıcan and Yaşar, 2015). So, it can be said that the interviewees of the study find sacrificing animals wrong.

Some of the interviewees stated that they don't sacrifice animals as they have some debts; based on these statements, it can be said that they see these debts as a positive thing, a kind of chance. They believe that faithful people can be vegans just like the ones who don't believe any religion. This is why; some Muslim vegans believe that the sentence 'Animals are created for human beings' is not acceptable. A woman who stated that she is a Muslim vegan and continues his daily life according to Islamic rules and practices mentioned that there is not a word as 'slaughtering' in Qur'an, so sacrificing an animal is not a practice that can be related with Qur'an. According to this type of Muslims, Islam defends peace and compromise, it doesn't command ensanguine: 'God creates, so God can claim lives'. A vegetarian who was graduated from the Faculty of Theology defends that sacrificing an animal for God is not a 'must'. According to him, sacrificing is based on a misinterpretation of Qur'an's language. The issue of sacrificing an animal is related to Islam, but it is rooted in Shamanism and 90\% of people in Turkey don't really know the meaning of Qur'an or really understands its messages. According to the people believing in this misinterpretation, grain donation can be made instead of sacrificing an animal; an animal can be sacrificed only when it is Hajj time (the specific time period for the pilgrimage to Mecca).

About sacrificing an animal and veganism in Islam, a vegan individual states that: "I believe that, when I put my hand on my heart, I can say that rather than a command, a piece of advice could be sufficient for me: You will treat others the way you want to be treated". Another interviewee especially stated that: "There are five pillars of Islam. There is no such thing as sacrificing an animal for Allah. Sacrificing an animal is not a binding duty (farz), it is necessary (vacip). Necessary (vacip) rules are close to binding duties (farz), but not like sunnah ... But if you completed Hajj pilgrimage, it becomes a binding duty (farz).

R. İhsan Eliaçık, who has a definite standing against sacrificing an animal for Allah, defines himself as an anti-capitalist writer and thinker, says that there is nothing as sacrificing in Qur'an. According to him, making an offering is the first ritual that occurred in the history of religions. The idea of sacrificing a living being had come before the idea of Allah (Özbirinci, 2015).

\section{In lieu of conclusion}

Although any kind of torture or exploitation of animals is forbidden in religions, the milk industry completely ignores this and animals are being seriously exploited in the facilities.

It is determined that most of the interviewees adopted the vegan lifestyle as they are effected from social media and friends.

Ethical reasons heavily influenced interviewees in the process of choosing and adopting this lifestyle. Belief in justice and witnessing the suffering of animals are some of the 
reasons. On the other hand, standing against animal exploitation is another ethical reason. As exploitation is related to capitalism, veganism is accepted as a theory against capitalism. All of the interviewees, Muslims, Atheists, and Deists share one common point: Standing against capitalism.

It is understood that individuals who live in families with Islamic lifestyles and the ones who live in Islamic social circle have serious difficulties while choosing a vegan lifestyle. While some of them cannot talk about veganism with their friends, some others don't share their ideas about veganism easily with their families or friends.

Some of the vegan interviewees define themselves as anarchists and they believe that they have chosen the right path; they believe in that while they should be respected by nonvegan individuals, they don't need to respect them.

It is seen that female Muslim vegans don't have an opponent standing against people who consume animal products. They cook meals with animal products to their family members and they respect people who consume animal products. On the other hand, it is seen that women who define themselves as atheist or deist vegans don't allow using animal products in their houses.

It is determined in this research that the biggest difference between Muslim and Atheist or Deist vegans is based on organization and self-expression. Atheist or deist individuals aim at being known with the identity of veganism and they want to be in communication with other vegans. On the other hand, Muslim vegans aim at preventing communication with other vegans. Muslim vegans in the study stated that rights and choices of non-vegans should also be respected. But it is also determined that they are disturbed by the individuals who use veganism as a tool for making propaganda and turn this identity into political power. They are against veganism as a political attitude, so they are against activist vegans. Activists believe that veganism is a political attitude, so they should be active in groups such as feminists or environmentalists. So, while atheist vegans are a part of political stance, Muslim vegans avoid political groups. On the other hand, it is seen that Muslim vegans can neither be a part of Muslim groups nor vegan groups who define themselves as atheists; they don't feel that they belong in a place among these groups.

Few of the vegans in the study believe that vegans should be purified from any kind of prejudices. According to them, veganism is a connection with the spirit. It is correct to say that viewpoints of vegans who define veganism as a kind of spirit is similar to those popular beliefs in the new age.

It is determined that there are some Muslim vegans who believe that the issue of sacrificial rituals has changed in time. Namely, vegans who defined themselves as Muslims find associating the act of sacrifice to Islam wrong

As a result, it is possible to say that including some individuals who believe that there are some misinterpretations about the issue of sacrifice, Muslim vegans are against sacrificing animals because of different reasons. 


\section{Endnotes}

1 Ferit Devellioğlu, Ottoman-Turkish Language Encyclopedic Dictionary

2 http://www.tdk.gov.tr/index.php?option=com_content\&view=frontpage\&Itemid=1

3 Mezmur 50:7-8. "I will not reprove thee for thy sacrifices or thy burn offerings, to have been continually before me. Mezmurlar 56:12-13: "The vows are upon me, O God: I will render praises unto thee."

4 Creation, 4: 1-16.

5 Âl-u İmrân 3/183.

6 Âl-u İmrân 3/183.

7 Bakara 2/127.

8 Torah, Tekvin (22), 1-19.

9 Bakara (2), 124-125, 127.

10 Exodus 29/36

11 Levitical 17/11

12 Levitical; 4/22-23. 4/27, 28, 32 and Numbers, 15/27. 5/7. 5/11-13.1/11. 4/5-7, 16-18; 5/9. Levitical, 4/4-10. $4 / 11,12,21.4 / 4,24,29$.

13 Matta, 26/26- 28; Markos, 14/22- 24.

14 Hebrew, 5/1-3.

$15 \mathrm{Hac}, 22 / 36$.

\section{References}

Armutak, A. (2008). Yahudi ve Hristiyan dini kutsal kitaplarında hayvan hakları. İstanbul Üniversitesi Veteriner Fakültesi Dergisi. S. 34 (1). pp. 39-55.

Aydın, N. (2016). Dünya'da ve Türkiye'de dinler-ırklar diller. İstanbul: Parola.

Baltacı, A. (2018). Nitel araştırmalarda örnekleme yöntemleri ve örnek hacmi sorunsalı üzerine kavramsal bir inceleme. Bitlis Eren Üniversitesi Sosyal Bilimler Enstitüsü Dergisi. S. 1 (7). pp.231-274.

Bekki, S. (1996). Türk mitolojisinde kurban. Akademik Araştırmalar. Say1 3.16-28.

Best, S. (2009). Encyclopedia of environmental ethics and philosophy. In J. B. Callicott \& R. Frodeman (Eds.). USA: Macmillan Reference.

Bottero, J. and Kramer, N.K. (2017). Mezopotamya mitolojisi. A.Tümertekin (Çev.). İstanbul: Türkiye İş Bankasi.

Bulut, M. (2011). Mardin'de evlilikler. folklor/edebiyat. Cilt:17. Say1: 66/2. 65-79.

Childe, G. (2005). Tarihte neler oldu. A. Şenel, M. Tunçay (Çev.). İstanbul: Kırmızı.

Cilac1, O. (1990). Dinler ve Insanlar. Konya: Damla.

Clarys, Peter, et. al. (2014). Comparison of nutritional quality of the vegan, vegetarian, semi-vegetarian, pesco-vegetarian and omnivorous diet. Nutrients, Vol. 6, pp. 1318-1332.

Cömert, M., Durlu Özkaya, F., (2014). Gastronomi turizminde beslenme engelleri kapsamında vegan beslenme örneği. Gazi Üniversitesi Turizm Fakültesi 15. Ulusal Turizm Kongresi, Engelsiz Turizm. 13-16 Kasım 2014. Ankara S. 492-498.

Degrazia, D. (2002). Hayvan hakları. H. Gür (Çev.). Ankara: Dost.

Diyanet İşleri Başkanlığı (2018). Kurban sıkça sorulan sorular. İstanbul: Diyanet İşleri Başkanlığı.

Dyett, P. Rajaram, S. Haddad E.H. and Sabate, J. (2014). Evaluation of a validated food frequency questionnaire for self-defined vegans in the United States. Nutrients, Vol. 6. pp. 2523-2539.

Düzbayır, B. (2013). Mukayeseli fikıh bağlamında kurban ve kurbanın hükmü. Çukurova Üniversitesi. SBE. Basılmamış yüksek lisans tezi. 
Eliade, M. (1994). Ebedi dönüş mitosu. Ü. Altuğ (Çev.) Ankara: İmge.

Erginer, G. (1997). Kurban. Kurbanın kökenleri ve Anadolu'da kanlı kurban ritüelleri. İstanbul: Yap1 Kredi.

Emiroğlu, K., Aydın, S. (2003). Antropoloji sözlüğ̈̈. Ankara: Bilim ve Sanat.

Erben, Ş., E., Balaban-Salı, J., (2016) Social media use of vegan activists in Turkey. Global Media Journal TR Edition. Vol. 6. No. 12. pp. 75-88.

Fieldhouse, P. (1996). Food and nutrition customs and culture. London: Chapman and Hall.

Francione, G., L. (2008). Hayvan haklarına giriş. Çocuğunuz mu köpeğiniz mi? R. Akman ve E. Gen (Çev.). İstanbul: İletişim.

Frazer, J. G. (2004). Altın dal: Dinin ve folklorun kökleri. Cilt: I. M. H. Doğan (Çev.). İstanbul:Payel. Frazer, J. G. (1992). Altın dal: Dinin ve folklorun kökleri. Cilt: II. M. H. Doğan (Çev.). İstanbul: Payel. Güç, A. (2003). Çeşitli dinlerde ve İslâm'da kurban. İstanbul: Düşünce.

Güngör, H. and Argunşah, M. (1991). Gagauz Türkleri tarih-dil-folklor ve halk edebiyatt. Ankara: Kültür Bakanlığı.

Gitt, W. (2012). ve diğer dinler? J. Yıldız (Çev.). GGP Media GmbH. Pößneck.

Hooke, S.H. (1993). Ortadoğu mitolojisi. A. Şenel (Çev.) Ankara: İmge.

Işık, M. (2011). Evrensel bir hadis denemesi: "Ben ve öteki”. Erciyes Üniversitesi İlahiyat Fakültesi Dergisi. 2011/1. pp. 143-154.

İnan, A. (1995). Tarihte ve bugün şamanizm. Ankara: Türk Tarih Kurumu.

Kınıkoğlu, M. (2015). Vegan beslenme. İstanbul: Oğlak.

Kutsal Kitap (2003). Kutsal kitap eski antlaşma (Tevrat, Zebur). İstanbul: Ohan.

Kümbetoğlu, B. (2005). Sosyolojide ve Antropolojide niteliksel yöntem ve araştırma. İstanbul: Bağlam.

Le, L.T. and Sabaté, J. (2014). Beyond meatless, the health effects of vegan diets: Findings from the Adventist cohorts. Nutrients. 6, 2131-2147. DOI: 10.3390/nu6062131.

Leitzmann C., (2014), Vegetarian nutrition: Past, present, future. The American journal of clinical nutrition. pp. 496-502.

Ögel, B. (2010). Türk mitolojisi, C.I. Ankara: Türk Tarih Kurumu.

Örnek, S. V. (1989). 100 soruda ilkellerde din, büyü, sanat, efsane. İstanbul: Gerçek.

Öztürk, Ö. (2016). Dünya mitolojisi. Ankara: Nika.

Öztürk, N. (2002). İlahi dinlerde yemin: Keffaret ve kurban. Selçuk Üniversitesi Illahiyat Fakültesi Dergisi. Vol. 13: pp. 167-193.

Öztürk, Y. N. (2013). Kuran'ı Kerim ve Türkçe meali. İstanbul: Yeni Boyut.

Phillips, F. (2005). Vegetarian nutrition. British Nutrition Foundation Nutrition Bulletin. Vol. 30. pp. 132-167.

Pollan, M., (2009). Etobur-otobur ikilemi. İ. Önelge (Çev.) İstanbul: Pegasus.

Pilis, W. Stec, K. Zych, M. and Pilis, A. (2014). Health benefits and risk associated with adopting a vegetarian diet. Rocz Panstw Zakl Hig. Vol. 65. No. 1 pp. 9-14.

Roux, J. P. (2005). Orta Asya'da kutsal bitkiler ve hayvanlar. A. Kazancigil ve L. Arslan. (Çev.). İstanbul: Kabalc1.

Schimmel, A. M. (1999). Dinler tarihine giriş. İstanbul: Kırkambar.

Sinmez, Ç. Ç., Arıcan, M., K., Yaşar, A. (2015). Hadislerde hayvanları koruma ve gönenci (refahı) üzerine bir değerlendirme. Erciyes Üniversitesi Veteriner Fakültesi Dergisi. Vol. 12. No. 2. pp. 115-121. 
Singer, P. (2005). Hayvan özgürleşmesi. H. Doğan (Çev.). İstanbul: Ayrıntı.

Smith, A. D. (2002). Ulusların etnik kökeni. S. Bayramoğlu and H. Kendir (Çev.). Ankara: Dost.

Stangroom, J. (2013). Din, büyük fikirlerin küçük kitapları. C. Batuk and S. Turan (Çev.). Ankara: Liman.

Sünnetçioğlu, S., Mercan, Ş., O., Yıldırım, H., M., Türkmen, S. (2017). Veganların restoranlarda karşılaştıkları sorunlar üzerine bir araştırma. Journal of Tourism and Gastronomy Studies Vol. 5/ 2. pp. 241-252.

Şahin, K. (2010). Dini kimliğin inşasında kutsal ve tabu olan yiyecek ve içeceklerin işlevleri: Antakya örneği. Hacettepe Üniversitesi. SBE. Basılmamış doktora tezi.

Tuğrul, S. (2010). Ebedi kutsal ezeli kurban. Ankara: İletişim.

Tunçay, G. Y. (2020). Biyoetik çerçevesinde vegan ve vejetaryenlik. Ankara:Vize.

Tunçay, G., Y., Bulut, M., (2019). A Bioethical Approach: Vegan and Vegetarian Experiences. Progress in Nutrition. Vol. 21, No. 2, pp. 375-381, DOI: https://doi.org/10.23751/pn.v21i2.6885.

Tunçay Son G. Y., Bulut, M., (2016) Yaşam tarzı olarak vegan ve vejetaryenlik [Vegan and vegetarianism as a life style] International Journal of Human Sciences. pp. 830-843.

Vance, E. (2016). İnancın gücü. National Geografic Türkiye.

Yetik, Z. (2012). Kabil. ilk kan, ilk cinayet, ilk katil. İstanbul: Pınar.

\section{Elektronik kaynaklar}

Çetin, Z., (2015). Vejetaryen ve vegan beslenmesi. http://www.medikalakademi.com.tr /vejetaryen-vevegan-beslenmesi/ [Retrieved 12 April 2017].

Karabudak, E. (2008). Vejetaryen beslenmesi. Sağlık Bakanlığı. No: 726. Ankara: Klasmat http:// beslenme.gov.tr/content/files/ arastirmalar/uyelik/beslenme_bilgi_serisi/Kitaplar/a /a_13_ vejeteryan_beslenmesi_48.pdf [Retrieved 07 June 17].

Kiran, J. (2015). Ne yesem ne yemesem. http://yunus.hacettepe.edu.tr/ demirsoy/Haberler. files/ beslenme.pdf. [Retrieved 25 April 2015].

Özbirinci Y., (2015). İhsan Eliaçık: Kuran'da kurban kesmek, LGBT'i öldürmek ve kadına şiddet yoktur. 20 Eylül 2015 tarihli röportaj, Gaia Dergisi, https://gaiadergi.com/ihsan-eliacik-kurandakurban-kesmek-lgbti-oldurmek-ve-kadina-siddet-yoktur/ (17.1.2018).

Türkiye Vegan Derneği [Vegan Association of Turkey] http://tvd.org.tr [Retrieved 12 Feb. 2020]

Türkmen, A.B. (2015). Topyekûn ve bütünsel bir özgürlük talebi: Veganlığın felsefesi. Gaia Dergi. https://gaiadergi.com/topyekun-ve-butunsel-bir-ozgurluk-talebi-veganligin-felsefesi/ [Retrieved 20 Dec. 2015].

VEBU - Vegetarierbund Deutschland, vegetarisch für profis. Die vegetarische küche. Vegetarian to pros. The vegetarian cooking] http://vebu.de/attachments /vebu_veg_fuer_profis.pdf [Retrieved 15 May 2015].

Vejetaryen Kulübü. http://www.vejetaryenkulubu.com. [Retrieved 27April 2015].

Vegetarian society. https://www.vegsoc.org. [Retrieved 25 Sep. 2020].

Yıldırım, Z. (2013) Ebru Arıman: Vejetaryenlik bir tercih meselesi değil, bir zorunluluk. http:// yesilgazete.org/blog/2013/10/07/ebru-ariman-vejetaryenlik-bir-tercih-meselesi-degil-birzorunluluk/ (1.12.2015). 
folk/ed. Derg, 2020; 26(4):859-882

DOI: $10.22559 /$ folklor.1403

\title{
Kültürlerarası Edebiyat Kuramı Bağlamında Taner Baybars Şiiri
}

\author{
Taner Baybars Poem in the Context of \\ Intercultural Literary Theory
}

\section{Mihrican Aylanç}

$\ddot{O} \mathbf{z}$

Batı dünyasında edebî ürünler ve şahsiyetlerin incelenmesinde oldukça sık kullanılmaya başlanan kültürlerarası edebiyat kuramı, Türkçede çok sınırlı tanıtım yazılarının dışında henüz ele alınmamıştır. Özellikle Avrupa'da 20. Yüzyılın ikinci yarısından sonra başlayıp günümüze kadar hızla yoğunlaşan kültürler arasındaki ilişki ve etkileşimler, edebiyat dünyasında da ilgi görmeye başlamıştır. Bu çalışmada ömrünün uzun yıllarını İngiltere'de ve bir süre de Fransa'da geçirmiş olan Kıbrıslı Türk kökenli, şair Taner Baybars'ın şiirlerindeki kültürlerarası değişim ve etkileşim unsurları, kültürlerarası iletişim sistematiği maddelerinden yararlanılarak ele alınmıştır. Metinsel içerik analizine gidilerek Taner Baybars'ın şiirlerinde kültürlerarası etkileşim ve değişimin, şairin poetikasının temel unsurları olduğu ortaya konulmuş; çokkültürlü ve çok dilli birikimin zengin verilerinden yararlanan şairin, yerli/ulusal odaklardan evrensel boyutlara ulaşmayı başardığı sonucuna varılmıştır.

Anahtar sözcükler: kültürlerarası edebiyat, Taner Baybars, kültürel etkileşim, kültür, çokdillilik

Geliş tarihi (Received): 11.03.2020- Kabul tarihi (Accepted): 19.09.2020

* Yrd.Doç.Dr., Uluslararası Kıbrıs Üniversitesi Fen-Edebiyat Fakültesi TDE Bölümü. maylanc@ciu.edu.tr. ORCID 0000-0002-0524-8131 


\begin{abstract}
Intercultural literature research is common in the study of literary works in Europe. However, this method has not been applied yet, except for very limited presentation text, in Turkey. In Europe, especially starting from the second half of the 20th century, interest in the relations and interactions between cultures has intensified rapidly in the world of literature. In this work, the elements of intercultural exchange and interaction in the poetry of the Turkish Cypriot poet Taner Baybars are discussed using the materials of intercultural communication theory. As a result of textual content analysis and descriptive studies in Taner Baybars' poetry, intercultural interactions and changes to be fundamental elements of the poet's poetica are shown. It has been concluded that Taner Baybars, who had been nourishimg from the rich data of multicultural and multilingual accretion, had succeeded in reaching universal levels from local/national foci.
\end{abstract}

Keywords: interculturel literature, Taner Baybars, culture, multilingualism

\title{
Extended summary
}

Taner Baybars (1936-2010) was a poet who was born in Cyprus and lived on the island in his early youth during which he received education, acquired the culture and gained life experiences on the island. Later, he moved to England and then to France, the effects of multiculturalism and multilingualism is reflected in his works. This article is the study of the poetic character and poems of Baybars. Besides writing poetry, he was also a painter with numerous paintings. In this article, the cross cultural elements that give personality and identity to his works will be identified and studied. Intercultural research has observably became widespread, Taner Baybars' works reflect the effects of different cultures on his poems and is also worthy of a praise for the comprehensive methodology applied in his work. As a fact, language is one of the most important tools in reflecting the cultural characteristics and accumulations of a society, Taner Baybars, who wrote his poems in three different languages occupies a position at the center of the theory in question. Learning another language and the use of natural tools of everyday life reveals new shifts and changes for the identity of the individual.

The method of analysis employed on the literary works in this study is cross cultural analysis method. Three subtitles of declarative knowledge (savoir) are based on; the theory of world view (culture générale), sociocultural knowledge (savoirsocioculturel) and intercultural awareness (prize de conscienceinterculturelle) theories helped to facilitate the history and principles defined for cross cultural theory used in this study, and has been used to examine the poems.

Interculturalism questions the unchallenged norms and dogmas by challengeing the reflections of foreign spaces and data in individuals.

The bridges created by interculturalism can turn differences between states, languages and even continents can turn into common / similar or changeable new phenomena . 
Intercultural theory defines the changes and interaction. However, the concept of crosscultural literature with its semantic unity centers on a new and different literary discourse instead of including literature on migration, refugees and literature relating to home sickness.

The change of borders or the formation of individual borders, intercultural literature research offers new approaches in cultural differences, partnerships and identity formation processes. In the intercultural literatury studies basically adresses the concept of multiculturalism.

Born in Cyprus, Taner Baybars immigrated to England at a young age, lived there for many years and then passed away in France, where he had immigrated. Constructing his verses, prose, pictures as well as his poetry with a knowledge distilled from different cultures extending from the native Cypriot to the British and the land of Franks. He applied his multilingual and multicultural experience to his works. There are limited studies on the works and poetry of Baybars, who migrated to England after writing his first book at the age of 18 and transitioned to a colonial subject . Mehmet Yaşın carried out the primary and important studies about Taner Baybars, describes the poet as a cosmopolitan with roots.

The following systematic has been applied in the examination of the poems of Taner Baybars in terms of interculturality:

In examining the reflections of the multiculturalism in poetry that this new artist identity revealed;

A- Cultural conflicts and cultural encounters in the content of the texts:

1. Symbols,

2. Heroes,

3. Rituals and values (Kartar1, 2001).

B- In structure:

1. Types of adaptations,

2. Language diversity,

3.Intertextuality and

4. Hybridity as the basic criteria (Mecklenburg 2008: 15).

Two basic binaries in the intercultural literary approaches; are cultural conflicts and encounters. Without entering the details of geography-centered (géo-littéraire) data, text analysis reveals that cultural encounters and conflicts constitute the general texture of Baybar's poetry when the poetry is thoroughly examined. The pominent differences that shape the basis of cultural encounters and conflicts are symbols, heroes, rituals and values Rituals and values have helped us to understand Baybars' process of interaction and acculturation that we mentioned earlier. Examples of genre adaptations (Mecklenburg, 2008: 15) are also encountered in the formal examination of Baybars poetry with a focus on intercultural literature.

Intercultural literary studies is a sub-discipline of comparative literary studies. It provides opportunities to reach concrete evaluations and results by revealing the multidimensional relations and interactions in the reception and assimilation of literary works.. The theory, can 
create bridges between generations, nations and geographies, as data in different focal points are handled; Concrete benefits can be obtained from the examination of literary works and personalities that are shaped through the relationships, contradictions and interactions between cultures.

Intercultural literature is in an effort to bring the subtleties of understanding and sharing to the agenda in the chaotic structure of the earth. by studying the reflections of religion, language and inter-civilizations dialogues on literary products, and the by analyzing the concept of "the other". Authors to be studied in this respect must have assimilated the multicultural atmosphere and reflected their knowledge in their works. Data analysis ranging from mythology, history, anthropology, sociology, psychology to linguistics of the work and determining the characteristics of the multicultural literary product fort he processes of such transfers.

In this research, cultural conflicts and cultural encounters in terms of content; In the formal sense, genre adaptations, language diversity, intertextuality and hybridity were examined with a methodical application on Taner Baybars' poems. There is limited research on the Works of Taner Baybars, who as a poet, shaped the poetic structure of Turkish with extensive expressions of English and French while diversifying the process of acculturation in the Middle East and the Mediterranean in Britain and France. Taner Baybars whose culture is based on the Middle East-Mediterranean culture; and as a poet who later absorbed the Anglo-Saxon culture, is on path of development from local to universal.

In this study, the Turkish translations of Baybars' poems, most of which are in English and some of them in French, were used and this creates the limitations of not being able to reach original texts. However, the fact that these translations of the poems were made by poets (such as Mehmet Yaşın, Gür Genç Korkmazel) or by himself, with the contributions of an artist, provided a relative solution in the research process.

In the early poems of Baybars, the geographical disperison of the works portray the local cultures which range from Famagusta to Üsküdar and to Istanbul . It fins representation with images such as the henna fingers in Cypre in the poem entitled Gülten, the satin of Cypres, the migration of the poet at a young age, and the new geography reflects the initial steps of the poet's method by including cultural conflicts and encounters. Although the cosmopolitan structure is mentioned, the transition from Cyprus, which has the typical features of the Mediterranean culture to the UK-centered western culture, followed by the French experience of the poet expands the dimensions of the mentioned conflicts and encounters. Symbols, heroes, rituals and values that shape the basis of cultural conflict reveal the new character of Baybars's poetry. The triple structure in the language, the cultural richness of data belonging to these languages, created the original structure in the expression focal points of Baybars's poetry. The fact that the years the poet lived coincided with the periods of intensified cultural transitions across Europe influenced the richness of multicultural metaphors and images, intertextuality, connotative, close and distant associations in his poetry. Taner Baybars, standing at the center of a wide range of interaction ranging from mythological data, ancient and contemporary literature to influential names / works of the art world, scientists, holy people and values, enabled the poet to convey different cultural elements to his lines in the routine wheels of daily life. 
Baybars has manifested the identity of a universal "poet of the world" without ignoring the humanistic point of view and employing the rich themes and competent expressions in his poetry and filtered by the culture of the geographies where history of humanity has been shaped.

\section{Giriş}

Baybars, belirgin ve açık seçiktir. Anlam katmanları ile mecaz ve imgeler arasinda sessizliği nasil kullanacağın iyi bilir.

Terry Eagleton ${ }^{1}$

Türk Edebiyatında henüz sınırlı örneklerini gördüğümüz kültürlerarası edebiyat araştırmaları, Batı dünyasında özellikle 20. Yüzyıl'ın ürünü olan kültürel çeşitlilik ve farklılıkların önem kazanmasıyla yaygın bir biçimde ele alınmaya başlanmıştır. Bu yaklaşım, özellikle çoklu kültür katmanlarının bulunduğu coğrafyaların ya da çokkültürlülüğü bireysel olarak yaşamış sanatçıların yaratılarındaki yapının çözümlenmesinde, edebiyat araştırmaları açısından yeni ufuklar açmıştır. Bireysel ve toplumsal entegrasyonların farklı kültürler içindeki konumları çeşitli oluşumlarla ortaya çıkmaktadır. "Yabancı" ve "yerli” birbirlerine muhalif konumdaki varoluşlarına rağmen zaman ve mekân içinde, "muhalifliğin" ötelendiği, etkileşim ve paylaşım ortamlarının oluştuğu gözlemlenmektedir. Kültürlerarası edebiyat bu temel yaklaşımla hem metinsel düzeyde hem de sosyo-kültürel bağlam açısından önem kazanmaktadır (Von Zimmerman, 2006: 8). Hâkim kültür, ön kabulünü bertaraf ederek kültürleri bütünleştiren bir yapılanmayı gündeme getirmektedir.

Kültürlerarası terimi, değişim ve etkileşimi sembolize eder. Ancak kültürlerarası edebiyat kavramının anlam alanında klasik göç, sığınma arayışı, ülke özlemi gibi kültürel deneyimlerin aktarılmasının yerine, yeni ve farklı bir edebî söylemin varlığı söz konusudur. Sınırların değişmesi ya da bireysel açıdan sınırsızlıkların (sınır ötesinin) oluşmasıyla birlikte kültürlerarası edebiyat araştırmaları kültürel farklılıklar, ortaklıklar ve kimlik oluşumu süreçlerinde yeni yaklaşımlar sunmaktadır. Burada kilit nokta, değişimin birden fazla yüzeyde gerçekleşmesi ve kimliğin oluşumuyla ilgili içgörünün (insight) ortaya çıkmasıdır. Sanatçıların yapıtlarına yansıyan kültürel kalıpların analizi, kültürlerarası izleklerin analiziyle çatışma ve çözümlemelerde yeni bakış açıları getirmektedir.

\section{Tarihsel süreçte kültürlerarası edebiyat kuramına genel bir bakış}

Kültürlerarası edebiyat teriminin irdelenmesinde temelde çokkültürlülük kavramından yola çıkılabilir. Kuramcılar, bir yandan "çokkültürlülük, çağdaş dünyada yaşamsal her şeye, birbirinden büyük oranda farklı olan insanların birbiriyle etkileşim içinde olduklarına ve birbirleriyle iş yapmaları gerektiğine işaret eder" görüşünü sunarken, diğer taraftan "bir toplumdaki bireylerin kendi kültürlerinin dışındaki verilerle iç içe olmalarının da toplumsal çokkültürlülüğü yarattığı” fikrini ortaya koymaktadırlar (Bozkurt, 2002). 
Kültürlerarası iletişim terimini ilk kez kullanan ABD'li antropolog Ruth Benedict, Krizantem ve Kılıç (1966) adlı eserinde Japon toplumunu antropolojik yöntemlerle ele alarak sonraki çalışmalara önemli bir zemin hazırlamıştır. İlerleyen yıllarda özellikle Avrupa'da kültürlerarası geçişkenliklerin çalışma hayatı, siyasal olgular gibi etmenlerle bireysel ve kitlesel göç hareketlerine yol açmasıyla her toplumda ortaya çıkan “öteki”nin konumu, kültürel çeşitliliği merkeze alan çok bileşenli yeni bir bakış açısını ve buna bağlı olarak kültürlerarasılığı yaratmıştır. Özellikle iletişimde önem kazanan kültürlerarasılık, giderek farklı alanlarda yeni bakış açılarının, yöntemlerin doğmasını sağlamıştır. Kültürlerarası iletişimin tarihsel gelişimi, ana damarda sosyal bilimlerin epistemik çizgisini sürdürürken bu temel yapısıyla kültürlerarası edebiyata da önemli yöntembilimsel katkılar devretmiştir.

Antik Uzak ve Yakın Doğu edebiyatlarının bireysel ürünlerinin zaman içinde sistematikyapısal varlıklarının estetik, ideolojik bağlamda -tür ve biçimlerde- metamorfozlara uğraması, kültürlerarası edebiyat ürünlerinin ortaya çıkmasını sağlamıştır. Bunun sonucunda II. ve VIII. Yüzyıllar arasında Çin Sincan/Türkistan ana merkezli ortak edebiyatın İpek Yolu boyunca Pamir, Semerkand, Buhara, Merv, Palmira rotasını izleyerek Tarsus-Antakya, İskenderiye ve Roma'ya ulaşıp Bizans'ta olgunlaşması, dört büyük evrensel kültürle (Avrupa Greko-Roman, Oryantal (Doğu) Batı, Güney ve Doğu Asya) kaynaşması, entellektüel bir gelişim yaratmış; kültürlerarasılık ve kültürlerarası edebiyat alanlarının oluşturulmasını sağlamıştır. Antik Yunan ve Hint geleneği ortak estetik sembolleri (interartistic symbiosis) yaratırken dinsel bağlamda Budist-Manihaizm-Nestoryen merkezli "géo-littéraire” edebiyat, mitik Babil Kulesi ile taçlandırılmış olan Sankritçe'ye dayalı kültürlerarasılığın edebî kimlikli başyapıtlarını ortaya koymuştur. Çin, Uzak Doğu, Okyanus çevresi, Himalayalar ve Tiyanşan'ın engin topraklarında tohumlanmış özgür ruh, kültürlerarası hoşgörü ve anlayış, Batıya seyahatini sürdürürken kültürü taşıyan, paylaştıran artık insanlar ve ulaşım araçları değil, yaklaşık altı bin dille kurgulanmış, beş bin yıllık maziye sahip edebiyat olmuştur (Galik, 2000: 4).

Bu durum Asya ve Afrika' da yeni edebiyatlar yaratırken Euro-Amerikan dünyası IX. ve XX. Yüzyıllar boyunca bu etkilenmeden uzak duramamıştır. Antik öncesi (pre-antic) ürünlerdeki genetik-iletişim işleyişi, daha sonraki zamanlardan kuşkusuz farklıdır. (Berdnikov,1989; Galik'ten). Ancak onlarda bulunan yapısal özellikleri irdelemeden daha sonraki dönemlerin olgun, yetkin örneklerini bile anlamakta güçlük çekilebilir. Avrupa ülkelerinde sömürgeci yapıların giderek ulus devlet kimliğine bürünmesi, iş gücü talebi, siyasal olayların doğurduğu devinimler "öteki”ni yeniden gündeme getirmiştir. Evrenselliği temel paradigmaları arasında kabullenen Batı kültürü, “yerel”e ve “ötekisi”ne gözlerini çevirdiğinde kültürlerarasılık ve bu bağlamda kültürlerarası edebiyat, temel ilke ve uygulamalarıyla Avrupa entellektüalizminde yerini almıştır.

Kültürlerarası araştırmanın sosyal, antropolojik ve psikolojik bilimlerde yaygın kullanılan bir metodoloji olması, kültürlerarası edebiyat araştırmalarını da önemli kılmaktadır (Gallagher ve Savage, 2012:1). Kültürlerarası edebiyat kuramının Rus ve Çek yapısalcıların temel paradigmaları kökeninde Orta Avrupa'da ortaya çıktığı varsayılır. Rene Wellek'in 1959 tarihli Karşılaştırmalı Edebiyatın Krizleri adlı çalışmasında vurguladığı "edebiyat bilimcileri, bireyin edebiyat dışı varoluşu ve varlık süreçlerini dışladıkları sürece hiçbir ge- 
lişim gösteremeyecekleri” yolundaki görüşünün kültürlerarası edebiyat araştırmalarını da gündeme getirdiği ileri sürülmektedir (Wellek, 1963; Galik 2000’den). Dionyz Durisin, 1989 tarihli Theory of Interliterary Process adlı çalışmasında kültürlerarası edebiyatın, karşılaştırmalı edebiyattan farklı bakış açılarını epistemolojik açıdan ortaya koyar (Galik 2). Kuramın paradigmalarında, ontolojik açıdan karşılaştırmalı edebiyatla koşutluk söz konusuyken, epistemolojik çerçevede ayrıldıkları dikkat çeker. Kültürlerarası edebiyat, karşılaştırmalı edebiyatın yöntemlerinden farklı olarak örtülü süreçsel karakter analizleri (implicit processual character) ile etnik alanda ilgili edebî gerçekleri içeren zamansal ve mekânsal değişimleri öngörmektedir. Kültürlerarası edebiyat, alanın araştırma süreçlerinde genetik-temas ilişkilerine dair fenomenleri saptama bakımından dikkat çekici bir konuma sahiptir (Galik 3).

Bu temel paradigmalar doğrultusunda alanın Türkiye'deki ilk kuramsal çalışmalarından birinde kültür ve edebiyat ilişkilerine değinilerek toplumlararası ilişkilerin edebiyata yansıması üzerinde durulur:

Farklı kültürlerin kırılgan bir temas içerisinde bir arada yaşadı̆̆ imparatorlukların heterojen bir kimliğe sahip edebiyatı, kültürlerarası edebiyat araştırmaları için bulunmaz bir hazinedir; çünkü kültürlerarasılık olgusu tam da böyle bir edebiyata yani farklı ama iç içe, birbirine benzemeyen ama birbirinden etkilenmiş olana vurgu yapar. Toplumlararası kültürel temaslar ister dostane iletişim şeklinde ister çatışma boyutunda olsun her şekilde edebiyatta yankı bulur; çünkü edebiyat toplumun bütün dinamikleriyle yansıd $\breve{g}$ l bir alan$\operatorname{dir}$ (Cengiz, 2014: 53).

Bu anlayış kapsamında üreten sanatçı açısından farklı coğrafyaların çokkültürlü katmanlarının sermaye olduğu zihinsel ve duygusal birikimler, yereli hatta bir noktada bireyseli aşarak evrenseli yakalamada, onunla koşut olmada yeni firsatlar doğurabilmektedir. Türk edebiyatı kapsamında kültürlerarasılık bağlamında hemen akla gelen Almanya'da yaşayan Türk kökenli sanatçılara, Avrupa'nın diğer ülkelerinde yaşayanlar da hızla eklenmektedir. Almanya'da Türk-Alman edebiyatı adıyla da sunulan bu oluşumun önde gelen isimleri arasında Alev Tekinay, Emine Sevgi Özdamar, Feridun Zaimoğlu, Aras Ören, Saliha Scheinhardt gibi yazarlar dikkat çekerken (Cengiz, 55) Demir Özlü, İskandinav kültürü içinde olgun eserler üretmiştir.

Kültürlerarasılık, emperyal süreçlerde egemenlik/hegemonya amaçlarıyla ortaya çıkmışken günümüz koşullarında kültürel ortaklıkların oluşmasında farklı kültürlerin kaynaşarak ortak enerji üretmesini sağlamaktadır. Kültürel kodların zengin boyutlarıyla edebî ürünlere yansıması ise, sözsel dinamizmin evrensel kaynaklarını yaratmaktadır. Kültürel özcülükle bağlantısız bir edebiyatın varlığını Türk Edebiyatı çerçevesinde tartışan Laurent Mignon, kültürlerarası edebiyat araştırmaları bağlamındaki farklı yönelimleri, yerli ve yabancı kaynakların irdelenmesi ve örneklendirilmesiyle ortaya koymuştur (Mignon, 2009).

Bu çalışmada, ilk dönem eserlerinde Kıbrıs Türk edebiyatı mensubiyetinden İngiltere’ye göçüyle evrensel bir kimliğe kavuşan Taner Baybars şiiri, kültürlerarası edebiyat bağlamında ele alınacaktır. 


\section{Taner Baybars şiirinin kültürlerarası edebiyat bileşenleri}

Farklı kültürlerin damıtılmış verileriyle dizelerini kurgulayan Taner Baybars (19362010), Kıbrıs yerelinden Britanya ve Frenk topraklarına uzanan evrensel yaşam çizgisini, şiirin yanı sıra düz yazı ve resimle de biçimlendirmiş; çok dilli, çokkültürlü bir birikimin estetik örgülerle süregelen 64 yıllık ömrünün çoğunu doğup büyüdüğü toprakların dışında geçirmiştir. Çocukluğunu Kıbrıs'ın Lapta yöresindeki Güzelyalı (Vasilya) köyünde geçiren Baybars'ın hayatındaki değişim ve dönüşümler, Minareliköy ve sonra Lefkoşa'ya taşınmayla tohumlanmaya başlar. O bir köylüdür, bir tarla çocuğudur, ă̆aç çocuğudur. Şimdi kaldırımlarla örülü şehirde büyümesi durmuştur, hayat durmuştur (Aylanç, 2011: 290). Kentteki eğitim süreciyle birlikte tarla çocuğu ă̆ır ă̆ır değişir (Aylanç, 2011: 294). İngilizce yaşamına girer, şiiri keşfeder, İstanbul aksanıyla konuşmaya başlar. Bu şekilde ikili bir kişilik geliştirir (Aylanç, 2011: 294). Çocukluk dönemlerindeki çokkültürlü ortam, Baybars'ın gelecekteki yaşama bakışını biçimlendiren özelliklere sahiptir:

Baybars spent his childhood always in mixed villages: Vassilia is referred to as a mixed village with its own Greek quarter (Baybars 2005, 15, 24, 37), while Lapithos had a significant Greek community, and also Minareli Köy was inhabited by both Turks and Greeks. Greek "neighbors," fishermen, doctors, wine merchants, or knife sharpeners, are always mentioned as something distant, living close but still not in the same quarter, underlining geographical as well as economic distance (Kappler, 2009).

18 yaşında yazdığı ilk kitabından sonra İngiltere'ye göç ederek kolonyel bir kimliğe geçiş yapan Baybars'ın şiiri, eserleri üzerine yapılan çalışmalar sınırlıdır. ${ }^{1}$ Şair hakkında ilk izlenim/yorumları ortaya koyan Mehmet Yaşın, Kıbrıs’ta Türk dilini işleyen en kuvvetli şairlerden biri olan Baybars'ın felsefi düşünce kaynaklı üslup özelliğinden söz eder (Baybars 1997, 11). Yaşın, Kıbrıslıtürk Şiiri Antolojisi adlı eserinde (anne tarafından ikinci kuzeni olan) Baybars'ın şairlik konusunda hak ettiği yere ulaşamadığını belirtir. Baybars hakkında yabancı edebiyat ve kültür insanlarının yorumlarını aktaran M. Yaşın, şairi kökleri var olan bir kozmopolit olarak niteler. Adada merkez-çevre (metropol-periferi) arasında kalmaktan kaynaklanan öznel iç çatışmaları sonunda, Londra'ya göç eden ve artık İngilizceyi kullanan Baybars'ın bireyciliği ön plana çıkardığını vurgulayan Yaşın, şairin 'ben merkezli' bir şiiri yeğlediğini ileri sürer (M. Yaşın, 2005: 99).

Taner Baybars hakkında yapılmış sınırlı sayıdaki çalışmalarda dikkat çeken ortak görüş; Baybars'ın yerel bir dil ve kültür içinde doğması, "adalı” kimliğine sahip bir gençlik tecrübesi geçirmesi, daha sonra bu kaynağa tümüyle kapılarını kapatarak -çocukluk ve gençlik yıllarından kalan fotoğrafları izlenim/hissetme boyutuna kadar küçültecek- uzun İngiltere yılları ve Fransa eklemli bir ömür sürdürmesi; edebî kimlik ve sanatsal tutumlar bakımından Batılı kaynakların (occidental) etkisinde kalmasıdır (Karahasan, 2004). Bu yönleriyle kültürlerarası edebiyat verileri bağlamında Baybars şiirinin ilginç örneklendirmeler sergilediği söylenebilir. Demiryürek, şairin Kıbrıs Türk kültürü izlerinin görülebildiği Türkçe yazılmış tek kitabı olan Mendilin Ucundakiler'de yer alan şiirlerin Garip akımının etkisinde yazıldığını ileri sürer (Demiryürek, 2016). Dolayısıyla şairin dünyasında yerel Kıbrıs Türk ve 
Müslüman kimlik, mutlak göç (adadan çıktıktan sonra bir daha dönmemiştir) sonucunda benimsediği Avrupa kültürü, İngilizce ve Fransızcanın egemen olduğu dilsel değişim, H1ristiyanlık izlenim ve ilişkileri ile sentezlenmiş/ yer değiştirmiş ve farklı bir kültürel kişilik oluşmasına yol açmıştır.

Bu yeni sanatçı kimliğin ortaya koyduğu çokkültürlülüğün şiirdeki yansımalarının incelenmesinde;

\section{A- Metinlerin içeriğinde kültürel çatışmalar ve kültürel karşılaşmalar:}

\section{Semboller,}

\section{Kahramanlar,}

3. Ritüeller ve değerler (Kartarı, 2001).

\section{B- Biçimsel yapıda:}

\section{Tür adaptasyonları,}

\section{Dil çeşitliliği,}

\section{Metinlerarasılık ve}

4. Melezlik temel ölçütlerdir (Mecklenburg, 2008: 15).

A- Kültürel çatışmalar ve kültürel karşılaşmalar: Karşılaştırmalı edebiyat disiplini, en az iki (edebî) fenomen arasında bir ilişkiyi ve etkileşimleri öngören "karşılaştırmanın" temel metodolojik perspektifini ifade eder (Matajc, 2009:1). Kültürlerarası edebiyat yaklaşımında da temel iki karşıtlık; kültürel çatışma ve karşılaşmalardır. Coğrafya merkezli (géo-littéraire) verilerin ayrıntılarına girilmeksizin şiirin geneline bakıldığında kültürel karşılaşma ve çatışmaların, Baybars şiirinin genel dokusunu oluşturduğu söylenebilir.

Yazarın İngiltere'de yazdığı aşağıdaki satırlarda görülen ruhsal seraplar halinde geçmişe yapılan yolculuklar, yerel kültürün etkilerini vermek bakımından ipucu niteliğindedir:

Klşın mangalda ince külün içine kor halinde odun kömürü gömülü. Bir tarafinda çaydanlık, öteki tarafinda Türk kahvesi için bir cezve. Annem, hep de aşk romanı olan bir kitaptan on ya da yirmi sayfa okurdu. Romanda işlerin iyiye ya da kötüye gittiği her defasında, ateşin çevresinde çömelmiş olan köy kadınları, ya sempatiyle ya da kınayarak başlarını sallarlardı. Kendileri kitaplarda basılı olanlardan çok daha ilginç hikâyeler anlatabilecekleri halde, onlara, bütün bunlar gerçekleşmiş gibi geliyordu herhalde. Yine de, eğitimli bir kadın tarafindan okunan basılı sözün büyüsü, onlarl vecde getirirdi. Annem çok kurnazdı; okumayl, heyecanlı bir bölümün sonunda bırakırdı (Baybars, 1997: 22-23).

Baybars'ın ada yerelliğinin yansıtıldığı ilk şiirlerinde bile tarihsellikle beslenen bütünlüklü bir kozmopolitan yapıyı imlemesi, onun ilerleyen dönemde varacağı noktayı gösteren bir tablodur. Ortak dil ve coğrafî yakınlığa bağlı Türkiye kaynaklı kültür ve sanat alanlarındaki yoğun etki, Baybars’ta sınırlı bir biçimde görülür. Kültürlerarası çatışmanın farklı ve karmaşık dinamizmi hayatı seziş, duyuş ve özümleyiş açısından karmaşık ve sürekli değişen sonuçlar ortaya çıkarır. Adadaki yerel kültürün farklılıklar içinde tohumlanmış bir boyutunu 
sergileyen yapısı, Baybars'ın erken dönem şiirlerine olduğu gibi yansır. Bir Rumeli türküsü olan Alişimin Kaşları Kara türküsünü;

Ve sen,

'Alişimin Gözleri Kara'

Türküsünü mırıldanarak

Odun dumanindan ă̆la

Gam ile değil, tasayla değil

Bu sonsuz bir ip çamaşırcı kadın

Hepimizi sen yıkamışsın

Akıtarak yavaş-yavaş

Damla-damla suyuтиzu.

Gün kısa, gece uzun

Çamaşırlar ipin üstünde

Farkında değiliz insan olduğumuzun... (Baybars, 1954: 21) biçiminde kullanması bu düşüncenin bir kanıtıdır. Pek çok Kıbrıslı Türk’ün gönlünde bir özlem merkezi olan İstanbul, Baybars'in dizelerinde de kendini gösterir:

Bakamam dăglara bakamam

Dağ-dağ olur gözümde hasret

Denizler bu kadar derin

Bu kadar uzak mı Güzel İstanbul

İçinde yanarken gözbebeklerin

Kâtip Üsküdar'da gider

Dudaklarımda Boğaziçi

Mağusa'da sallanan mendiller

Ve her titreyen elde

Seni görmenin sevinci

Dalından düşüyor yaprak

Düşemem ah düşemem

A ̆gaç olamam ki ben insanoğlu

Kuşlar taşısın meyvelerimi

Bahçelerine Istanbul'un (Baybars, 1954: 40-41).

Mağusa'dan Üsküdar'a uzanan mendiller Kâtibim şarkısında dizelere taşınırken mekâna duyulan özlem ve görme sevinci, kuşlarla gönderilen meyvelerle dile getirilir. İlk gençliğini yaşadığı adasından şairde en çok yer eden unsur, son şiirlerine kadar bolca kullandığı deniz, su ve kuş imgeleridir. Baybars'ın şiirlerinde çocukluk ve ilk gençlik yıllarının yaşandığı ve artık uzaklarda kalmış olan Kıbrıs, sınırlı dokunuşlarla yansıtılır. Neşe Yaşın’ın deyişiyle; 
Taner Baybars' '̇n Kıbrıs'ta geçen Müslüman çocukluğu-dinsel bir kimlikten öte kültürel bir kimliktir bu-sonralarl farklı dinler ve kültürlere duyduğu ilgiyle zenginleşir. Sünnet deneyimini anlattığl şiirine çan kuleleri karışır. Uzak bir ülkeye dönüşen anayurdu Kıbrıs, zaten bir kimlik bunalımı mekânıdır. Kendini içine doğulmuş, verili, dayatılmış kimliklerden azade eden Baybars, bu üniformalarl giymese bile onların deneyimlerini ve zenginliğini ekler kendine... Şiirlerini şaşırtıcı, az bulunur bir melez imgeler cennetine dönüştürür (N. Yaşın, 2017).

Daha sonraki yıllarda ana yurtla ilgili şairin bilince yerleşmiş sınırlı örneklerden biri; O’nun babasına yazdığı Memlekete Mektup başlıklı şiirindeki dizelerdir:

(...)

Memleket hasreti?

Hayır, çünkü bir memleketim olmadı hiçbir zaman benim

ama sen değilsin bunun suçlusu

Yine de, deniz ile dă̆ birarada anımsıyorum

geceleyin birbirinden sonsuz uzaklaşan

ama ikisi arasında sallanan beşiğimi (Baybars, 2007: 37).

İngiltere’ye göç sonrası yeni kültürlerin etkisindeki şiirlerinde çevreyi bireysel bir bakış açısıyla yorumlayan Baybars'ın yıllar sonra ilk kez Kıbrıs'ı çocukluk sevgilisi Gülten'e (Gül) yazdığı şiirine yerleştirirken de özünde günceli betimlediği gözlemlenir:

\section{$(\ldots)$}

Bronzlaşan ten, güneşin tende kiraladı̆̆ yazlık

hatırlatır bana Cypre'yi hatırlatır bana, o kınalı parmaklar

okul bahçesinde, selvi kozalakları vardı hani

ve gül'dün sen, iplikleri belleğin- örneği bulunmayan

Cypres sateni, mekik dokuyan şifreyi çözüyorum

düğ̈̈mleri, teyellenmiş kenarlarını senin çıkrı̆̆ında (2007:133).

Taner Baybars'ın şiirlerindeki kültürel karşılaşma ve çatışmaların ikinci basamağı İngiltere'dir. Yeni bir ortamda, farklı bir dilin önce iletişimsel sonra sanatsal üretimindeki sarsıntıları, şairin yeni kimlik verileridir. Böylece yeni bir dille karşı karşıya gelen birey, aslında kendi kültürünün dışındaki bir başka kültürü de kabul etmeye hazır olmaktadır (Roche, 2001:16). Bu görüşe koşut olarak sanatçının kendi diline karşı sorgulayıcı bir tavır edindiği ileri sürülür:

Bu süreç içinde birey kendi diline tam olarak hâkim değilse, yani dilini iyi bilmiyorsa, öncelikle ikinci dili öğrenme aşamasında zorlanır. İki dil arasında bitip tükenmeyen nedensiz karşılaştırmalar yaparak, öğrenmeye çalıştı̆̆l yapılar arasında kurmayı denediği neden sonuç ilişkileri aracılı̆̆lyla-kendince- anlamlı bir sonuca ulaşmaya çalışır. Bu çabanın doğal bir uzantısı olarak bireyde kendi diline, tarihine ve kültürüne karşı sorgulama süreci başlar (Çakır 77). 
Yeni dilin temel olduğu yeni kültür odağı ve kültür verileri, şairin dizelerinde önce Britanya sonra Avrupa odaklı olarak özgürce boy gösterir. Kentteki geniş bulvarlar, Thames üzerindeki köprü ayaklarında oluşan dalgacıkların sergilediği balayı, nehre sineden düşen uzun kurdela, siste, yağmurda parlayan Westminster'in çan kuleleri, Trodos'un, Beşparmakların, Akdeniz'in yerini alır, yağmurda ıslanan kilise çanları, bilinçaltında bir buğday ya da yulaf tanesinin parlayışını anımsatır:

Geniş caddeler üstünde parlldyor sis

Thames nehri bir sineden düşen uzun bir kurdela.

Köprü ayaklarındaki dalgacıklar balayında,

ya koltuk değnekli bir kötürüm gibi

topallıyor dalgacıklar üstünde (...)

Curzon Sokağı'nda güzel bir icattır günah

ve erdemlilik parllyor Westminster'in çan kulesinde,

siste, yă̆murda

bir buğday ya da yulaf tanesinin parladı̆̆ gibi. (Baybars, 2007: 30).

Aynı şiirde bu iki boyutlu duygu evreninin merkezi de boğuk sedalı kilise çanları gibi, dizelerin arasından çınlar;

Adsız bir çanın çaldığını duymaktayım:

London, London, London (30).

Dizelerin devamında kültürel çatışma ve karşılaşmanın teşhisi ilân edilir:

Duvarlar nefesini tutar, ağaçlar gıcırdar

çıplak bir dakika şaşılacak şeyler doğurur;

benim kıllı göğsüm, fazlasıyla uzamış tırnaklarım

ve trafĭgin nă̆mesiz gürültüsü (31).

İngiltere'deki ilk yılların sarsıcı, sarsıntılı dönemlerinden sonra benzer göç olguları sonucu bireyde meydana gelen değişimlerin seyri evrensel bir düzleme taşınır.

Birey yaptı̆̆ karşılaştırmalardan usanıp, kendini tamamen öğrendiği ikinci dile (kendini onu konuşan topluma adayarak) verir. Karşılaştığı her bir yeni olguyu ki bu bazen tek bir sözcük bile olabilir, hayranlıkla karşılar ve bundan nedensiz zevk alır. Hatta karşılaştığı her yeni olgu, onun için mutlak bir ideal olarak vazgeçilmez bir anlam kazanır. Süreç bireyin kültür ve kimlik çatışmasına kadar uzanabilir (Roche, 2001: 37).

Ömrünün sonuna doğru Fransa'da iken ana diline dönerek Türkçe yazdığı Kaybolmuş Kardeşler...Ben? başlıklı şirinde şairin bilinçaltında saklı duran Kıbrıs ve Kıbrıslılığının diğer kültürler arasındaki gel-gitlerinin izdüşümü resmedilir: 
Evet...kayboldum, işte öyle, çok pek çok zaman geçti,

Uzak ülke o, uzak düşlerden daha uzak doğduğum yer,

isimler, resimler, hatıra-satıra, kahve fincanında geleceğim:

Klş duvarında evimin açılmaz yaz panjurları?

Vasilya'daki tavuk kümesinin kokularl geliyor burnuma... ...

Hatırlyyorum çoğunu ben, berrak gözleriyle baklyorlar bana..

O dillerde olmayan şehitler, ıssız köylerin nemli okullarında

Şehit olmak yanız tüfek ateşiyle değil, mitralyözle değil, değil...

(Baybars, 2007: 250) dizeleri, ana yurdunda geçirdiği çocukluğunun ve acılı tarihin Baybars'ın benliğine yerleşmiş olgular olduğunu ve bu olgulardan kaçamadığını somutlar. Valras-Plage (Güney Fransa) şiirinde çocukluğunu geçirdiği Vasilya/ Güzelyalı (Kıbrıs) imajı zihninde Arap bir kadının yüreğindeki yurt hasretiyle depreşirken çan sesleriyle feryada dönüşür:

Uyku çapakla sıvamış kirpiklerimi, göremiyorum.

Haa, açıldılar; Vasilya değil burası, ak'ını yitirmiş deniz,...

Çan sesleri, gemi direklerine çarpan halatların feryadı

( ...)

Turuncu bir kubbe gibi çömelmiş bir Arap kadını

Yurt hasretiyle basıyor bağrına gamzeli küçük kızını. (2007: 251).

$\mathrm{Bu}$ süreçte kültürel karşılaşma ve çatışmaların temelini biçimlendiren farklılıklar ise semboller, kahramanlar, ritüeller ve değerlerdir (Kartarı, 2006: 4).

1. Semboller: Şiirde simge kullanımına ağırlık vermiş olan Baybars, kültürel çatışma ve karşılaşma kapsamı içinde yakın ve uzak çağrışımlar, yan anlamlar yoluyla ve genelde özel adları kullanarak çok katmanlı bir şiir dili yaratır. Kolomb’un Dönüşü şiiri, kâşif Kolomb ve adamlarının hissettiği umut, umutsuzluk, yaşam tutkusu; kimi zaman da an'ların ne denli değerli olduğuna dair hislenmelerine bağlı sembollerle örülüdür. Şairin yaşama bakış açısını simgeleyen şiiri ise, Kutsal Kitaplar'dır. Başlığın çağrışım alanına tezat oluşturacak biçimde bir yandan kutsallığın kaynaklarına göndermeler yapılırken şiirin devamında Darwin, Karl Marx, Freud ve Einstein gibi bilim insanlarının yapıt ve düşünceleri birleştirilerek bir tür öznel, düşünsel bileşime varılır:

Ilk modern sapma bilirim Darwin'i, kopuş

çă̆daş gerçeğe doğru.

Toplumsal şafağında onun, Karl Marx belirir,

sonra karmakarışık bir aklı çözüp düzelten Freud. 
Kımıldar parmaklarım ve Einstein'la karşılaşırım,

elinde kemanı, evrensel bir notayı çalan,

samanyollarını ölçerek her ince telde. (Baybars, 2007: 65).

Baybars'ın şiirinde sembol kullanımı alışkanlı̆̆ını yansıtacak somut örnek, O'nun Centaurus 'ta Gül Paskalyası adlı şiiridir. Centaurus burcundan (takımyıldız) yola çıkan şair, dilin anlatım gücünden yararlanarak güneşe en yakın gezegen Alpha Centauri'ye, Jung-Fu heksagramına, Hıristiyanlığın temel taşlarından Saint-Augustine ile Saint Paul'e uzanırken, kuantum fiziğinin öncü isimlerinden Niels Bohr'u dizelerine farklı sembolik anlamlar içinde yerleştirir. Şiirin sonu da Yunan alfabesinin ilk ve sonuncu harfleriyle kurgulanır, böylelikle yaşam ve ölüm sembolize edilir:

Geri gelsin diye kaybolan, kazandı̆̆ım uzay yılları, koyar

beni ön kesesine,

nerede biterse bitsin yolumuz, ne yaşta, ne çıkar? Biziz Alfa ve Omega (2007: 233).

Göksel varlıklarla ilgili sembolik metaforlar Baybars şiirinin süreklilik gösteren özelliklerinden biridir. Süratle Kaçan Işı̆̆ı̆ Sesi şiirinde Kara Delik kaosun sonsuzluğunu simgelerken burçlar (Yengeç, İkizler) anlam taşıyıcılıklarıyla Prometheus'u imler. Şairin başka şiirlerinde de yer verdiği Çin'in en eski kitabı sayılan ve Konfüçyüs ile Tao üzerine etkisi olan şiirin dipnotunda vurgulanan I Jing kitabında kandilçiçeklerinin saplarıla yapılan antik remil atma geleneğine göndermeler yapılır. Artemis'in ızdırabı (Söz-Böcek şiiri), Baküs'ün çift yaşam süresi (Tilkiye Dönmüş Baküs), Catullus'un dizelerinin şiirine taşınması, bu kapsamdaki örneklerdir.

2. Kahramanlar: Baybars'ın tarihsel kahramanları Romalılar, Crosoe, Pan, Ianus, Kolomb, Horatius, Romalı şair Catallus gibi evrensel kültürü yoğuran diğer tarihi şahsiyetlerdir. Suyu arayan ağaç kökleri gibi yaşadığı yeni kültürün can damarlarının ardına düşen Baybars, mitoloji -ve tarihi- şiirinde önemli bir kaynak olarak görür: Kır Sarhoşluğu şiirinde eski zamanları sızdıran bir köyün duvarlarında Romalıların yankılanan savaş çığlıklarından söz eder. Kâş̧ifler şiirinde mitolojinin evrensel motifi Pan'ın ölümünü Kutupyıldızlyla birleştirir. Tekin Olmayan Olaylar şiirinde buhranlı bir gecenin acıları içindeyken vücudunun bir tarafının Medusa'ya dönüştüğünden dem vurur. Roma mitolojisinin öne ve arkaya yani gelecek ve geçmişe bakan; eski ve yeni yılın sembolü çift başlı tanrı Ianus, (Şiirin dipnotunda bu tanrının Latin dilindeki January, Janvier biçimleriyle Ocak ayına ad olduğu belirtilir) hem simgesel hem şairin kahramanlarından biri işlevleriyle Noel'in 21. Günü başlıkl seri şiirlerin 17.sinde görülür. Mitolojinin popüler simgelerinden biri olan Kantauros, Ölçüsüz Ayrllk Var Aşk Olmayan Yerde adlı şiirde (122) aşk ve arzu duygularının amaca ulaşmasında vuslat imgesi olarak kullanılır:

Ben yerde, sen yumuşak yastıkların arasinda, yağllyorsun

abanoz karınaltını, bir Kentauros'un beklerken binmesini üstüne (2007: 122). 
Yunan mitolojisinde Thebes'li Apollon'un kör bilgelerinden olan ve yedi y1l müddetle kadına dönüştürülmesiyle ünlü Teiresias, karmaşık ve bunalımlı kişiliğiyle şairin ruh dünyasını aktarmada bir simge olarak kullanılır:

Ah Teiresias, o benimle olmadı̆̆ında O'yum ben,

ben kendimim o benimleyken;

faltaşı gözlerle baktım ona çok defa,

alkolden körleşmiş; umarım hissetmeye devam edeceğim

hünerli sol elinin elim üstündeki seğirmesini. (1995: 158).

Öte yandan Baybars şiirinde görülen kahramanlar albümünün önemli bir bölümünü de filozof, yazar, şair ve müzisyenler oluşturur. Tepelerde Vicdan Azabı şiirinde Vergilius'un Tityus, Amarillis ve Amyntas hakkındaki konuşmasını işler; Horatius'un doğa güzelliklerine, şelalelerine göndermeler yapar. Noelin 21. Günü şiirlerinin 5. sinde Theocritus'un ünlü, ineğin boğaya dönüşüm anekdotunu ironik bir tutumla dizelerine yerleştirir. Filin Hortumundaki Sünger şiirinde Herakleitos'un düşün dünyasının yanı sıra Ezra'yı ve yumuşak yastıkta dinlenen sessiz dilini düşünüyorum dizesiyle hayatının son yıllarını kimseyle konuşmadan geçiren şair Ezra Pound'a gönderme yapar. Pound'un bilinçli suskunluğunun Baybars'ı oldukça etkilediği Ezra'nın Sessizliği şiirinden algılanabilir. Aynı şiirde Diyojen ile İskender'in ünlü diyaloguna da atıf yapılır (118). Edebiyat dünyasından Marcel Marceau (Noel'in 21. Günü, 18), Hemingway ile Goethe ve eseri Faust Tilki Şairler Arasında şiirinde (Baybars, 2007: 205) bir araya gelir. Feylesof Kapısı Önünde başlıklı şiirde Shakespeare'in derin yalnızlığı, Ayasofya ile özdeşleştirilerek yansıtılır. Liszt'den (Sally Ann Hodges şiiri, 252) Kyleie Minogue, Elton John, Stevie Wonder, David Bovie'ye (Baybars, 1997: 158) uzanan bestekârlar, müzisyenler (117) dizelerde görülür. Baybars, Kristof Kolomb’un Yalnızlı̆̆ s şiirinde kendi derin ruhsal yalnızlığını uçsuz bucaksız okyanusta bir umudun ardına düşmüş olan Kolomb'un kaotik kişiliğini irdeleyerek kederini paylaşabilir insan, ama umudunu asla ifadesiyle anlatır. Aynı şiirin ilerleyen dizelerinde Vespucci ve Marco Polo da yeni umutların simgesi olan yeni mekânların kâşifleri ve şairin ruhsal arayışlarındaki engin açılımların sembolü olarak anılır (125).

3. Ritüeller ve değerler: Baybars'ın İngiltere ve Fransa günlerinde Hıristiyan kültür ve sanat verilerine sempati ve yakınlık duyması, dizelerine somut bir biçimde yansımıştır. Köklü bireysel kültürel değişimlerin oluşum ve sonuçlarını irdeleyen bir çalışmada ileri sürülenler, Baybars'ın daha önce değindiğimiz etkileşim ve kültürleşme (acculturation) sürecini anlamamızda yardımcı olabilir:

Bu aşamada, arayış içinde olan birey kültürel farklılıklarını görmezden gelmeye başlar. Kendini dıştan gelen farklı etkilere karşı savunmaktan vazgeçer. Kimi zaman açıklayamasa da karşılaştığ farlılıkları sorgulamadan kabul ederek 'alışılmadık' olana saygı duymaya, olumlu bulduklarını algılamaya, benimsemeye, kendi yaşamında uygulamaya başlar ve sonuçta kendi kültürüne ait olanlardan rahatsı olmaya ve ötekini tercih edecek şekilde özünü dışlamaya varan bir dizi duygusal süreç yaşar (Çakır 78). 
Aslında Kutsal Kitaplar şiirinde gerçeği o kadar uzakta aramamak gerektiğini vurgulayarak ilk modern sapma bilirim Darwin'i kopuş/ çağdaş gerçeğe doğru/ Toplumsal şafağında onun, Karl Marx belirir (Baybars, 2007: 65) derken bilim ve felsefeye öncelik veren Baybars, daha sonraları Romalılarının yankılanan savaş çığlıklarından (26) yola çıkarak kilise, Hıristiyanlık, papazlar, çan kuleleri, paskalya, azizler, gibi odaklarda sprituel bir yönelişin içinde olur. "Noel'in parlaklı̆̆ı, hindi geleneği, Noel kartları, doğrudan bir Sistersiyen Manastırı'nın bulunduğu St. Bernard Dă̆ı başlıklı şiir, farklı şiirlerde Robert, Paul, Patrick adlarını taşıyan pederler, Salve Regina ilâhisi, akşam ayinlerindeki ilahiler (185), Tanrı'ya Doğru Düşlemek şiiri (186), Haç çıkarıp oturdum ve alev alan kilise stralarına baktım/ sevgiyle kurutulmuş çiçekler gibi parlayan gibi dizeler (169) ve benzer unsurlar, değinilen dinsel kimliğin yansımalarıdır. Bu şiirlere yerleşmiş olan dinsel değerlerle ilgili veriler, Hıristiyan inancı sistematiğinde kişinin varlığının kutsal kılınması evresinde gözlerini varlıklardan tekrar Tanrı'ya çevirerek ve Tanrı'nın değerlerine koşut düşünce ve inanışlar kuşanarak kutsal'ı güncele taşıma çabasını göstermektedir (Tidball, 2009: 125). Baybars'ın bu bağlamdaki dizelerde bencillik ve çıkarcılık kavramlarına açık bir karşı duruş sezinlenmesine karşın bu duruşun protest bir tavır yerine insancıl (hümanist) bir tutumla biçimlendiği söylenebilir. Bunun dindarlıktan başka bir şey olduğunu vurgulayan Baybars, Ama tinsel, politik veya çoğu kavram gibi din de bir milletten başka millete veya bir bireyden öteki bireye farklı bir kılığa girer diyerek Maimonides (Musevi), St. Augustine (Hıristiyan) ve İbni Sina'nın (Latin metinlerinde Avicenna- Müslüman) kendi düşünsel birikiminde önemli etkileri olduğunu ifade eder. Ayrıca Yunus Emre'nin insancıl din anlayışı ile Dede Korkut'taki konuya ilişkin mesajların kendi dinsel düşünce oluşumlarında yeri bulunduğunu vurgular (Baybars, 2014: 123-124). Baybars'ın Hıristiyan mistisizmi ile ilişkileri ya da etkileşimi konusundaki bir yorumda ise; Baybars, kendinden beklenmedik bir durum olsa da, ilgi çekici bir tarzda $\mathrm{Hl}$ ristiyan mistisizmine yöneliyor ve bu izlek, ondaki sevginin bir başka boyutunu başarlyla dile getiriyor denilmektedir (Sidwick\& Jackson- Baybars, 1997'den:139). Şairin Munçak Pençesi adlı şiirinde de kendi ilham perisi olduğunu söylediği Çinli Miu merkezinde Hz. İsa'nın semaya yükselişini simgeleyen Yükselme Günü'ne (Ascencion) atıf yapılır:

Miu, sevgilim; annem, dadım; sorarım ona ne gördü benim dışımda, uzay yolları buluştu mu O’nunkiyle, Yükselme Günü'nde? Yok, Miu gitmişti çok daha evvel bir Zaman'a, Yaşam hâlâ bir meram Allah'ın elinde.

(2007: 232).

Bu eğilimin oldukça açık görüldüğü; farklı ritüel ve mistik unsurların bir araya geldiği şiirlerden biri olan Centaurus 'ta Gül Paskalyası (233)'nda, başka bir şiirinde de andığı antik Çin kitabı Il Jing'de bulunan Centaurus (burç, takımyıldızı), Jung Fu adlı heksagram, Hıristiyanlığın en önemli adlarından St. Augustine, Hz. İsa, Saul (St. Paul), Alfa ve Omega gibi sembol ve ritüeller, spirituel bağlamda Hıristiyan inanç ve terminolojisi kullanılarak işlenir (233).

\section{B. Biçimsel anlamda kültürlerarası edebiyat}

1. Tür adaptasyonları: Baybars şiirinin biçimsel anlamda kültürlerarası edebiyat odaklı incelenmesinde tür adaptasyonları (Mecklenburg, 2008:15) örneklerine de rastlanmaktadır. 
Geleneksel Türk şiirinin dörtlük biçimini kullanmayan Baybars, 1951-1953 yılları arasındaki şiirlerini topladığı Mendilin Ucundakiler adlı kitabında değişik şiir biçimleri kullanır. $\mathrm{Bu}$ şiirleri, farklı sayılardaki dizelerden oluşan bentler halinde yapılandıran Baybars, sadece Veresiye başlıklı şiirinde daha sonra örnekleri sık görülen kısa şiir denemeleri yapar:

Bir can aldım veresiye / Ne olur bütün borçlarım gibi, / Bir unutulsa bu da.

(2007: 17).

Zaman Kıranlar (2001; Baybars 2007 içinde) adlı kitabındaki şiirlerinde uzun dizeli biçimsel uygulamalar yapan Baybars, Fransızca yazdığı şiirleri arasında Haiku biçimini de kullanır:

Fizik-Kuantum Haikusu

Kaosta bir kelebek-

ilkbaharda kanatlarımı çırpıyorum

ama sevgilimi öldürüyor firtına

hüzünlü bir sonbahar günü. ( 97 ).

Biçim denemeleri arasında Trajik Bir Illham Perisine Sahte Kaside (2007: 182) adlı şiiri, Osmanlı şiirindeki klasik kaside örgüsündedir.

2. Dil çeşitliliği: Küreselleşen dünyada ulusal kültürlerin ilişkileri konusunda yeni formlar ve içerikler gündeme gelmektedir. Dinler, ideolojiler, demokratik değerlerdeki farklılıklar, toplum içi kültürlerarası diyalogda sorunlar yaratırken çok dillilik bu aşamada önemli çözümler ve seçenekler ortaya koyar (Venera vd. 2016:1).

Baybars ilk dönem ürünlerinde Türkçeyi kullandıktan sonra İngiltere'de yazdığı şiirlerinde İngilizce, daha sonra yerleştiği Fransa'da da Fransızca şiirler yazmıştır. Şiirin başka bir dile çevrilmesinde bile karmaşık sorunların yaşandığı bilinirken Taner Baybars'ın üç farklı dilde şiir üretmesi, dil çeşitliliğinin somut göstergesidir. Şiirin evrensel boyutlarında farklı dillerde ürün veren Baybars, bir yandan o dillerin ayrı anlatım varsıllıklarından yararlanırken diğer yandan da o dillerin renkli kültürel verilerini dizelerine taşır. Üç dilin anlatım olanaklarından hareketle kendi şiir dilini yaratmış olan Baybars, metafor oluşturma, mecaz, yan anlam, uzak çağrışımlar gibi teknikleri doğal bir akış içinde dizelerine yansıtabilmiştir. Yaşadığ yapılan bir röportajda bu konuyla ilgili olarak; Dil dediğimiz, her gün içimize çektiğimiz ve dişarlya verdiğimiz hava gibi bir şeydir. Birisi tamamen Ingilizce bir çevrede yaşayıp da, içine çekip dışarıya verdiği dilden etkilenmekten kaçınabilir. Iç̧inde doğduğu dili artık duymaz olur insan. (...) Benim durumu da, ayrıca Türkçenin değişen doğası sorunu var. Bazı modern metinlerin çok az anlamı var benim için, çünkü bu dil her zaman yeniden yaratılıyor (Baybars, 2014: 119-139) derken dil-şiir dili ilişkisine yönelik görüşlerini ortaya koyar. Baybars'ın çok dilli şiir üreterek İngiltere ve Fransa gibi etkin edebî merkezlerde eleştirmenler tarafından saygın/takdirkâr bir biçimde yorumlanması dikkat çekicidir:

Şiirlerini bir ikinci dilde yazmanın güçlükleri, Taner Baybars’1 mevcut şiir gruplarının baskı ve etkisinden çıkarıp, çağdaşı olan Britanyalı şairler karşı- 
sında avantajlı duruma getirdi ve o, hiçbir zaman, üslup, tarz ya da konu bakımından moda şiir anlayışlarını izlemek gibi bir eğilim göstermedi (Howard Sergeant- Contemporary Poets- Baybars 1997'den, 12).

Hangi edebiyata ait olduğuna dair kendisine yöneltilen bir soruya verdiği yanıt ise, onun kültürlerarasılık konusundaki konumunu belirleyebilecek niteliktedir: İnsana sahip çıkan köken değil dildir. Joseph Conrad'ı Polonyalı bir yazar; Nabakov'u Rus; Tom Stoppard'1 Çek ve Rushdie'yi Hintli olarak sınıflandırmak gülünç olur...Inanıyorum ki beni, 'Kıbrıs doğumlu (veya Kıbrısl-Türk kökenli) Britanyalı şair' olarak tanımlamak en uygunu olacaktır (2014: 126). Baybars'ın kişisel dil evrenindeki üçlü yapının kimi zaman çatışma, kimi zaman “çok dilli belleğinden” kaynaklanan açmazlara yol açtı̆̆ görülür:

Tatll-sert dil belirsizleşiyor, sözcük

sözcükle iç içe.

Kabuk üstünde kabuk, dikilen taht

üstünde bir diken-Yakınım seni yanıma alacă̆ım

söz sözcükten koparken, çok-dilli belleğim (1997: 71).

Şair, bu dizelerde kullanılan "kabuk, taht ve diken" imgeleriyle belleğindeki dillerin çatışma ve iç içeliğini vurgular.

3. Metinlerarasılık: Kültürlerarası edebiyat araştırmalarının biçimsel anlamdaki alt dallarından biri olan metinlararasılık, genel anlamda metnin göndergeselliği ile bağlantılı bir dizi dış etkenin (toplumsal, tarihsel, siyasal vb.koşullar) göz önünde bulundurulmasını gerektirmektedir (Aktulum, 2018: 233-256). Taner Baybars şiirinde metinlerarasılık, anlam zenginliği yaratmanın yanı sıra çeşitli kültürlerin verilerini belirlemek amaçlarıyla da önem kazanmaktadır. Çamaşır Ípi (Baybars, 2007: 179) adlı şiirinde bir halk türküsündeki “Alişimin Gözleri Kara" dizesini olduğu gibi şiirine yerleştiren Baybars, çok etkilendiğini birkaç şiirinde vurguladığı Robinson Crusoe'ye göndermeler yapar (Baybars, 2007: Deniz Kenarında Akşam). Eski Yunan-Roma şairleri dizelerde yer alır (Tepelerde Vicdan Azabı-Baybars, 2007). Mitolojik söylenceler, adlar, motifler aktardıkları ya da anıştırdıkları anlamlarla şiirlerde görülür: Pan (34), Medusa (114), Horatius (149), Hepahistos (162), Ianus (165), Catallus (172). Dante ve Ilahi Komedya'dan sahneler Çölde Sel Baskını adlı şiirde resim görselliğinde dizelere taşınır:

(...)

Dante'nin cehennem görüntüsü bu, Gary Packer'ın çı̆̆lı̆̆l

gırtlak dolusu bir darbe acı üzerinde. Anlayamaz o bunu:

ya bozar ya da kurar heykelleşmiş masumiyetiyle (2007: 203).

Tilki Şairler Arasında başlıklı şiirde hüzünlü ölümleriyle bilinen E. Hemingway, Amerikalı şairlerden Hart Crane ve kurtuluş arayışında kaçışa sığınan J. Berryman'a göndermelerde bulunulur: 
Tetiği çekmeden önce tahmin etmeye çalışlyorum

ne düşündüğünü Hemingway'ın; Hart Crane ne yapardl

atlamadan önce çökseydi üstünde durduğu köprü?

Şu amansız sürüşte dikiz aynası mıydı

John Berryman'ın basıp gitme kararına yol açan? (2007: 205).

Baybars, Gebe Gölgeler adlı kitabının Noel'in 21 Günü başlıklı şiir dizisinin 21'incisinde sıra dışı yaşamı ve şiirleriyle hayatı boyunca âşık olduğu tek kadın olan Lesbia’ya adadığı şiirleri ile tanınan ve genç yaşta ölen Romalı şair Catallus'un dizelerini şiirine montajlar:

“Ah Lesbia, Lesbia'm benim

\section{kimlerin kollarında horluyorsun şimdi"}

yeni yıl yată̆ımda hınçla Catallus okurken ben? (174).

Aynı şiirde İspanyol oyun yazarı Tirse de Molina’nın 1630'da yazdığı El Burlador de Sevilla adlı oyunun ünlü kahramanı Don Juan'ın trajik macerasına gönderme yapılır:

Don Juan'ın birçok fethi oldu ama olmadı hiç sevgilisi.

sahi, kimdi bunu söyleyen? (174).

Şairin farklı amaçlarla şiirlerine konuk ettiği Robinson Crusoe, Bir Bisiklet Yolculuğu şiir dizisinin üçüncüsünde bir kez daha anılır. Dizinin dördüncü şiirinde Sezar'a karşı gelen Brutus'un ordusunda savaşmış bir şair olan Horatius ve çağdaşı Vergilius'un şiirlerine göndermeler yapılır. Roma, Likya kahramanları olan Tityus Amaryllis ve Amyntas'ın adlarına yer verilir. Baybars, Kutsal Kitaplar başlıklı şiirinde çağın ve uygarlığın bilim kaynakları olarak yorumladığı Darwin, Karl Marx, Freud ve Einstein'ın adlarını anar, yapıtlarına açık göndermelerde bulunur; Bebek Kuğurmaları şiirinde Proust'un kişiliği ve yapıtları vasıtasıyla "bebek" imgesinin soyutluğunda "saflığı" sorgular (93). Bir kaç deneme de yaptığı Haiku tarzı şiirin babası olarak bilinen 17. Yüzyıl Japon şairi Başo’nun dizelerini, Sonbahar Yaprakları" adlı şiirinde insan ve doğa arasındaki devinimleri, ruhsal yüzleşmeleri yansıtmak üzere alıntılar. Mitolojinin çirkin olmasına karşın en güzel tanrıçalarla evlenen tanrısı Hephaistos, ironi çağrışımlarının aracı olur:

\section{Tekrarlarken yatakta Noel şarkılarını minik horlamasıyla}

ve bir mum yakarım ben Hephaistos'ça bir ironiyle, gülerek oynarım (162).

Baybars, Tilki ve Beşik Yapanlar adlı şiir kitabının girişinde Fransa'nın doğusunda yaşayan postacı kadın Pascale'ın başından geçen gerçek olayları şiirleştirdiğini "ön not” olarak açıklar. Buna göre zamanın sathiliğinde mekân, gerçek ve daimidir. Kişiler ise gerçekçi olmalarına karşın büyücülük, beddua ve kutsama yollarıyla sürekli biçim değiştirirler. Çok yönlü yaşamlar arasında mücadele eden insanın çaresizliği ve başkaldırmaya muhtaçlığını imleyen kitabın epigrafında ise John Clare'ın (1793-1864) Delilik Iç̧inde Yazılmış Şiirler kitabından bir bölüm yer alır. Aynı kitapta bir Çin atasözü de ayrı bir sayfada alıntı olarak yer alır (204). Karantina şiirinde Kral Lear'e atıf yapılırken (214) “Tilkiye Dönmüş Baküs” 
(216) adlı şiirde mitolojinin ünlü şarap ve bereket tanrısı Baküs'ün (Diyonisos), sembolü olan asma gibi ölüp tekrar dirilmenin; öte yandan da acı ve haz arasındaki devinimlerin sembolü olduğuna dair kapalı gönderimler izlenir:

$(\ldots)$

Kopmuş zincirinden gömleğimin içine kaylyor altın haç.

Uzun zaman geri dönmesini bekledim onun, beklerken

içime boşalttım tek bardaktan, çift yaşam süresini Baküs 'ün..(216).

Geçmişin Falına Bakmak (220) şiirinin dipnotunda şiirde geçen Çin'in en eski fal kitaplarından olan I Ching'de bulunan runik simgelere, gerçekleşmemiş kehanet olgularına açık göndermeler yapılır.

4. Melezlik: Hayatını Kıbrıs, İngiltere ve Fransa'da geçirmiş olan Taner Baybars, kültürel açıdan tipik bir melez kişilik örneğidir. İnsanlık tarihindeki karşılıklı kültürel etkileşimle ortaya çıkan farklı uygulama ve biçimler, küreselleşen dünyanın yeni bir hüviyetini ortaya koymaktadır. Bu konuda yapılmış kılavuz nitelikteki temel çalışmalarda sosyal yapıdaki değişim ve dönüşümlerin evrensel boyutları üzerinde durulmuştur (Burke, P. 2011). Kimlik, kültür ve melezlik kavramları, günümüz toplumlarının temel yapısal özelliğini oluşturma süreçleri arasında yer alır. Öte yandan Baybars'ın özellikle İngiltere'de yaşamaya başladığı ilk dönemlerde Britanya'nın renkli kültürel peyzajı, buradaki farklı kültürlerin birlikteliği, şairin eserlerinde çokkültürlülüğün çokça yer etmesini sağlamıştır (Gelfand vd 2008-Kültürlerarası Psikoloji'den s.344) Bireysel melezleşme her ne kadar toplumlararası devinimlerden soyutlanamazsa da, tekile indirgenen melezleşmenin temel paradigmaları arasında dil ve uzam farklılık ya da varsıllıkları ön planda gelmektedir (Holton, 2013). Dildeki melezlenme terimini ilk kullanan dilbilimci Mikhail Bakhtin, çok sesli anlatıcılığın etki ve gücüne işaret etmiştir (Yıldız, 2014: 35). Bu bağlamda Taner Baybars'ın Douanier Rousseau başlıklı şiiri, çokkültürlü etmenlerin dilde yarattığı melezleşmeye bir örnektir:

We left Dieppe in the brightness of sun

and found Newhaven as much sunned and coy

and tiptoeing through the Customs in the car

we stopped in front of a sentry who,

lifting the bonnet with his little finger,

laughed: monsieur-dame, sortez. But Why?

What about this cake os sun, smell of fruit

and this little bit of French cloud in here? (1997: 90).

Kültürlerarası Psikoloji öğretisinde entegrasyon ve çokkültürlülük kavramları hem kültürlerin kimliklerinin ve kültürel özelliklerinin devamlılığını öngörür hem de geniş ölçekli çoğul toplumda katılımı gerektiren tutumu ön plana çıkarır (Abayhan, 2015). 
Kültürel melezlik eksenindeki bu kuramsal çerçevede Taner Baybars, tipik bir melez/hibrid kültür oluşumunun merkezinde duran bir şair görüntüsü vermektedir. Göç ettiği İngiltere'de anadilin şiirsel sermayesinin üstüne kurduğu İngiliz ve Fransız dilleri, Baybars’ta salt sözsel ifade/anlatım odağından değil, düşünce, bakış açısı ve yorumlama açılarından da geniş bir spektrum yaratmıştır. Bu bağlamda şairin konumu ve önemi hakkında Enis Batur'un Kırk yılda bir Türkçe şiir yazdl, ama kırk yıldır Türkiye'de yazılan şiirlerin çoğundan daha iyisini yazdı değerlendirmesi dikkat çekicidir (Baybars, 1997: 13). Evrensel kültürün mitoloji verilerinden, farklı kaynakların birikimlerine girebilmiş olan Baybars, yukarıdaki maddelerde örneklendirilmeye çalışılan başlıklarda görüldüğü üzere; Akdeniz türkülerinden pastoral söylemlere, klasikleşmiş diyebileceğimiz dünya edebiyatlarının ışıltılı evrenlerine, tinsel duyuş, coşku ve spiritüel sarmallarla oluşan kendine has bir melez/hibrid şiir dünyası yaratmıştır.

\section{Sonuç}

Karşılaştırmalı edebiyat araştırmalarının bir alt disiplini olan kültürlerarası edebiyat, günümüzde edebî ürünlerin algılanması ve özümlenmesinde eserlerdeki çok boyutlu ilişki ve etkileşimlerin incelenmesine olanak sağlamaktadır. Bu kuramla, farklı odaklardaki veriler ele alındığından kuşaklar, uluslar ve coğrafyalar arasında köprüler kurulabilmekte; kültürler arasındaki ilişki, çelişki ve etkileşimlerden beslenen edebî eserler ve şahsiyetlerin incelenmesinde somut yararlar elde edilebilmektedir.

Kültürlerası edebiyat, din, dil ve uygarlıklar arası diyalogların edebî ürünlere yansıma biçimleri ve "öteki” kavramını çözümleyici niteliğiyle yeryüzünün kaotik yapısında anlayışlılık ve paylaşım inceliklerini yeniden gündeme getirme çabası içindedir. Bu anlayış bağlamında ele alınacak sanatçıların çokkültürlülük atmosferlerini özümlemiş; bu bağlamdaki birikimlerini yapıtlarına yansıtmış olmaları başat özelliktir. Mitolojiden, tarihe, antropolojiden, toplumbilime, psikolojiden dilbilime uzanan veri analizleri ve bunların edebî ürünlere taşınma süreçleri, çokkültürlü edebî ürünün niteliklerini belirlemektedir.

$\mathrm{Bu}$ araştırmada içerik açısından kültürel çatışmalar ve kültürel karşılaşmalar; biçimsel anlamda da tür adaptasyonları, dil çeşitliliği, metinlerarasılık ve melezlik temel ölçütleri, Taner Baybars'ın şiirleri üzerinde yöntemsel bir uygulamayla irdelenmiştir. Eserleri hakkında sınırlı araştırma yapılan Taner Baybars, Ortadoğu, Akdeniz temelindeki kültürlenme sürecini, Britanya, Fransa topraklarında çeşitlendirirken Türkçenin şiirsel yapısını İngilizce ve Fransızcanın geniş anlatım kaynakları ile biçimlendirmiş bir şairdir. Taner Baybars, temeli Ortadoğu-Akdeniz kültürüne dayalı; sonrasında Anglo-sakson kültürünü özümlemiş bir şair olarak yerelden evrenselliğe doğru bir genişlemenin odağında bulunmaktadır. Ondaki bireysel varoluşun yetişkinlikte farklı coğrafyalardaki uyanışı ise çocukluğunun geçtiği Kıbrıs'ın farklı dil ve dinlerin bir arada bulunduğu çokkültürlü yapısını gündeme getirmektedir.

Baybars'ın ilk dönem şiirlerinde Mağusa'dan Üsküdar'a, İstanbul'a uzanan coğrafi yayılımla boy gösteren yerel kültür, Gülten şiirinde Cypre'deki kınalı parmaklar, Cypres'in sateni gibi imajlarla yansıtılırken genç yaşta gerçekleşen göç, yeni coğrafya, yöntemin ilk 
basamakları olan kültürel çatışma ve karşılaşmaların da sahnesi olur. Her ne kadar kozmopolit yapısından söz edilse de Akdeniz kültürünün tipik özelliklerini taşıyan Kıbrıs’tan İngiltere merkezli Batı kültürüne geçiş, ardından şairin Fransa tecrübesi, değinilen çatışma ve karşılaşmaların boyutlarını genişletir. Kültürel çatışmanın temelini biçimlendiren semboller, kahramanlar, ritüel ve değerler, Baybars şiirinin yeni ırasını ortaya koyar. Dildeki Türkçe, İngilizce ve Fransızca olmak üzere üçlü yapı, bu dillere ait kültürel verilerin zenginliği, Baybars şiirinin anlatım odaklarındaki özgün yapıyı yaratmıştır. Şairin yaşadığı yılların Avrupa genelindeki kültürel geçişkenliklerin yoğunlaştığı dönemlere rastlaması, şiirlerde çokkültürlü metafor ve imge zenginlikleri, metinlerarasılık, yan anlam, yakın ve uzak çağrışımların sergilenmesinde etken olmuştur. Mitolojik verilerden, eski ve güncel edebiyattan sanat dünyasının etkili isimlerine/eserlerine, bilim insanlarına, kutsal kişi ve değerlere uzanan geniş etkileşim alanının merkezinde duran Taner Baybars, günlük yaşamın rutin çarklarında da farklı kültürel unsurları dizelerine aktarmış, kültür ve kimlik ekseninde dili öne çıkararak kültürlerarası bir şiir dünyası yaratmıştır.

İnsancıl bakış açısını göz ardı etmeyen Baybars, insanlık tarihinin biçimlendiği coğrafyaların kültürüyle süzülmüş şiirinde yer alan zengin izlekler ve yetkin anlatım ürünleriyle evrensel bir "dünya şairi” kimliğine ulaşmıştır.

\section{Notlar}

1 Taner Baybars, Seçme Şiirler, s. 12

2 Bu çalı̧̧malar içinde Meral Demiryürek'in Kıbrıs 'tan Britanya'ya Uzanan Bir Ada İnsanı: Taner Baybars adlı makalesinde (Kıbrıs Araştırmaları ve incelemeleri Dergisi, 1-2 Ocak 2018a s. 79-94) Baybars'ın genellikle İngilizce ve ayrıca Fransızca şiirler yazarak koloniyel bir özellik kazandığı vurgulanarak, makalenin Hitit Üniversitesi FEF 19001. 14. 002 kodlu "Taner Baybars Hayatt-Sanatı-Eserleri" başlıklı bitmiş projenin verilerinden yararlanılarak yazıldığı vurgulanır.

3 M. Demiryürek, Taner Baybars-Osman Türkay-Talat Halman Mektuplaşmaları Bağlamında Türk Edebiyatı (III. Uluslararası KIBATEK Kıbrıs Türk Edebiyatı ve Edebiyatçıları Sempozyumu, 2018b) çalışmasında Osman Türkay'ın yanı sıra Taner Baybars'ın da yurt dışında Türk edebiyatının Batı ülkelerinde tanıtılması için çabalar sergilediğini açıklar.

4 Meral Demiryürek'in İngiltere'de Bir Kıbrıslı Türk Yazar Taner Baybars ve Çevirileri, (XI. Uluslararası Büyük Türk Dili Kurultayı, 2016) adlı bildirisinde ise şairin eserlerini oluşturması sürecinde Kıbrıs etkileri ele alınır.

5 T. Baybars hakkında bir başka yazı, Emel Kaya’ya aittir. Kaya, 13 Mayıs 2017 tarihli Yeni Düzen gazetesinde yer alan Yaşamın Sinir Uçlarında Taner Baybars Şiiri başlıklı çalışmasında "pek çok temayı, insanı irdelemek, insanın yeryüzündeki hacmini, yaşama anlam katma çabasını kavramak için kullanan şairin tematik çeşitlilik, anlam katmanları oluşturulmuş incelikli, dolaylı, yer yer ironik bir dilsel zenginlikle” dikkat çektiğini vurgular.

\section{Kaynaklar}

Abayhan, Y. (2015). Kültürlerarası ilişkiler. (Kültürlerarası psikoloji ortak kitabında), İstanbul: Nobel. Aktulum, K. (2018). Metinlerarasılık görüngüsünde gerçeklik ya da metnin göndergeselliği. Bilig. Türk Dünyası Sosyal Bilimler Dergisi, 85: 233-256.

Aylanç, M. (2011). Kıbrıs Türk romanında göç. İstanbul, TC Marmara Üniversitesi Türkiyat Araştırmaları Enstitüsü Türk Dili ve Edebiyatı Anabilim Dalı Yeni Türk Edebiyatı Bilim Dalı,Yayımlanmamış Doktora Tezi.

Baybars, T. (1954). Mendilin ucundakiler. (Tilki ile Çobanaldatan içinde). Lefkoşa: Çardak. 
Baybars, T. (1997). Seçme şiirler: 1947- 1997, İstanbul: Yapı Kredi Yay.

Baybars, T. (1997). Uzak ülke: Bir Kıbrıs çocukluğu. B. Ö. Düzgören (Çev.). İstanbul: Yapı Kredi.

Baybars, T. (2007). Tilki ile çoban aldatan-Toplu şiirler (1951-2001). G. Korkmazel (Çev.) İstanbul: Yap1 Kredi.

Baybars, T. (2014). İspinozlar. Lefkoşa: Işık Kitabevi.

Benedict, R. (1996). Krizantem ve kılıç-Japon kültür önekleri. İstanbul: İşbankası.

Berdnikov, G.N. (1989). Istoria vsemirnoi literatury (A History of World Literature). Moscow: Nauka.

Berry, J. W. (2015). Kültürlerası psikoloji-Araştırma ve uygulamalar. L. P. Tosun (Çev. Ed.) İstanbul: Nobel.

Bozkurt, N. (2004). 20. yüzyll düşünce akımları. İstanbul: Morpa Kültür.

Burke, P. (2011). Kültürel melezlik. M. Topal (Çev.). İstanbul: Asur.

Cengiz, S. (2014). İmparatorluktan ulus-devlete çokkültürlü kimliklerin ifade alanı: Kültürlerarası edebiyat. Akademik Sosyal Araştırmalar Dergisi, 6:50-57.

Çakır, M .(2010). Kültürlerarası iletişimin bir yönü: Özün ötekileştirilerek yabancılaştırılması. Anatolia Turizm Araştırmaları Dergisi, 1: 75-84.

Demiryürek, M. (2016). İngiltere'de bir Kıbrıslı Türk yazar Taner Baybars ve çevirileri. XI. Uluslararası Büyük Türk Dili Kurultayı.

Demiryürek, M. (2018a). Kıbrıs'tan Britanya'ya uzanan bir ada insanı: Taner Baybars. Kıbrıs Araştırmalart ve Incelemeleri Dergisi, 1-2: 79-94.

Demiryürek, M. (2018b). Taner Baybars-Osman Türkay-Talat Halman mektuplaşmaları bağlamında Türk Edebiyatı. III. Uluslararası KIBATEK Kıbrıs Türk Edebiyatı ve Edebiyatçıları Sempozyumu.

Durisin, D. (1989). Theory of interliterary process. Bratislava: Obzor.

Galik, M. (2000). Interliterariness as a concept in comparative literature. Comparative Literature and Culture. 4:1-7.

Gelfand, M., L., M. Erez, and Z.Aycan, (2007). Cross-cultural organizational behavior. Annual Review of Psychology, 58: 479-514.

Gallagher, S. E. and T. Savage (2013). Cross-cultural analysis in online community research: A literature review. Computers in Human Behavior, 29: 1028-1038.

Holton, R. (2013). Küreselleşmenin kültürel sonuçları. K. Karaman (Çev.). Sosyoloji Konferansları Dergisi, 47: 59-75.

Kartarı, A. (2001). Farklılıklarla yaşamak: Kültürlerarası iletişim, Ankara: Ürün.

Kaya, E. (2017). Yaşamın sinir uçlarında Taner Baybars şiiri. Yeni Düzen Gazetesi, Lefkoşa.

Matajc, V. (2009). Literariness as interliterariness, cosmopolitan 'Author' and 'Interpreter'. Primerjalna Knjizevnost , 32: 213-232.

Mecklenburg N. (2008). Das mädchen aus der fremde-Germanistik als interkulturelle Literaturwissenschaft. Münih: Iudicium.

Mignon, L. (2009). Ana metne taşınan dipnotlar-Türk edebiyatı ve kültürlerarasıllı üzerine yazılar. İstanbul: İletişim.

Roche, Jörg. (2001). Interkulturelle sprach didaktik: Eine Einführung. Tübingen: Günter Narr Verlag.

Tidball, Derek (2018). Kutsallık; Tanrı'nın şaheserinin onarılması. U. Demirgil (Çev.). İstanbul: Haberci Basin.

Ulusoy, H. Ö. (2017). Kültürlerarasılık, çokkültürlülük ve etnisite: Eskişehir'deki Çerkeslerin kültürlerarası iletişim pratikleri. Akdeniz İletişim Dergisi, 27: 165-181. 
Venera R. A., Gulfia R. Gainullinab, Oksana V. Shemshurenko (2016). The interliterary dialogues' heuristic potential on the lessons of the Russian literature in the mulyiethnic environment. IFTE 2016: 2nd International Forum on Teacher Education.

Von Zimmerman, C. (2006). Kulturthema migration und interkulturelles schreiben. Recherces Germaniques. ed. C. Maillard, Revue Annuelle, 3:7-25.

Yaşın, M. (2005). Kıbrıs şiiri antolojisi. İstanbul: Adam.

Yaşın, N. (2017). Taner Baybars'ın Babil kulesi. Yeni Düzen Gazetesi. Lefkoşa.

Yıldız, T. (2014). Saussure'den Bakhtin'e dil-kültür ilişkisi: Tümü kapsayıcı olgu. İdil, 3.

Wellek, R. (1963). The crisis of comparative literature. Concepts of criticism. Yale UP. 282-95.

\section{Elektronik kaynaklar}

Kappler, M. (2009). Remembering a childhood in Cyprus: Taner Baybars' "smellscape" and multiculturalism in his autobiography, plucked in a far-off land" in Turkish literature and cultural memory. Multiculturalism as a Literary Theme after 1980. (Editor: C. Dufft). https://core.ac.uk/download/ pdf/41126075.pdf. (erişim 09.08.2019).

Karahasan, H. (2004 ). The politics of national identity and the idea of 'home' in Taner Baybars' 'Letter to homeland' and Mahmoud Darwish's 'A gentle rain in a distant autumn' and '1dentity card”, www.researchgate.com/file:///C:/Users/CIU/Downloads/JCS2004-Paper\%20(1).pdf(erişim 18.02.2019) 